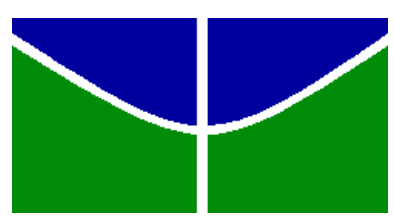

UNIVERSIDADE DE BRASÍLIA INSTITUTO DE CIÊNCIAS HUMANAS

DEPARTAMENTO DE GEOGRAFIA

PROGRAMA DE PÓS-GRADUAÇÃO EM GEOGRAFIA

RENATA SILVA ALMEIDA

INDICAÇÃO DE ÁREAS PRIORITÁRIAS PARA A PROMOÇÃO DA SUSTENTABILIDADE NA RESERVA BIOLÓGICA DA CONTAGEM 


\section{INDICAÇÃO DE ÁREAS PRIORITÁRIAS PARA A PROMOÇÃO DA SUSTENTABILIDADE NA RESERVA BIOLÓGICA DA CONTAGEM}

Dissertação apresentada ao Programa de Pós-graduação em Geografia, do Instituto de Ciências Humanas da Universidade de Brasília como requisito da obtenção do título de Mestre em Geografia.

Linha de pesquisa: Geoprocessamento

Orientador: Prof. Dr. Valdir Adilson Steinke 
FOLHA DE APROVAÇÃO

\title{
Título: INDICAÇÃo dE ÁREAS PRIORITÁRIAS PARA A PROMOÇÃo DA SUSTENTABILIDADE NA RESERVA BIOLÓGICA DA CONTAGEM
}

\author{
Aluna: Renata Silva Almeida \\ Linha de pesquisa: Geoprocessamento
}

Dissertação submetida à Comissão Examinadora designada pelo Colegiado do Programa de Pós-graduação em Geografia do Instituto de Ciências Humanas da Universidade de Brasília como parte dos requisitos para a obtenção do título de Mestre em Geografia.

Brasília, 11 de Agosto de 2016.

Banca examinadora:

Prof. Dr. Valdir Adilson Steinke

Presidente (Departamento de Geografia/UnB)

Prof. Dr. Edilson de Souza Bias

Membro interno (Instituto de Geociências/UnB)

Prof. Dr. Edson Soares Fialho

Membro externo (Universidade Federal de Viçosa) 


\section{AGRADECIMENTOS}

Agradeço primeiramente a Deus por renovar meu fôlego diariamente, para seguir em minha jornada com fé, equilíbrio e serenidade.

À minha família pelo incentivo, carinho, segurança e respeito em todos os momentos.

À Universidade de Brasília, Instituto de Ciências Humanas e ao Departamento de Geografia pela orientação e suporte.

Ao meu orientador, Dr. Valdir Adilson Steinke, pelos ensinamentos e condução deste trabalho.

Aos meus amigos pelo apoio, pela força e compreensão de minha ausência no período de produção.

Aos amigos e colegas pela ajuda e motivação: Ana Paula Cunha, Emmanuel Carlos Guimarães Moreira, Maribel Olaya Betancur, Juliana Faria Nunes, Stella Côrrea, Mariana Serpa Bonfim da Silva e Luiz Felipe Valle Silvestre.

Aos amigos Anna Carolina Finageiv e Diogo Olivetti pelas ponderações, críticas construtivas e sugestões. Foram de grande valia.

Em especial ao meu amigo, Lucas Tavares Sobral, pelo aprendizado compartilhado e registro de imagens aéreas da Reserva Biológica da Contagem.

Ao meu mestre de capoeira, Luiz Renato, pelas palavras, gestos de incentivo e confiança.

Ao servidor do ICMBio, Enrique Mieza Balbuena, pelas informações disponibilizadas, pela prestatividade, prontidão e credibilidade.

Ao servidor do IBAMA, Jorge Piccolo, pelas informações sobre a Reserva e pela logística de campo.

À equipe do $2^{\circ}$ Batalhão Rural do Comando de Policiamento Ambiental de Brasília. Em especial ao soldado Conti e sargentos Menezes e Airton, pelo acompanhamento, apresentação do local e por fazerem a segurança numas das visitas à área de estudo. 
A Terra provê o suficiente para a necessidade de todos, mas não para a voracidade de todos.

(Mahatma Ghandi) 


\section{RESUMO}

Esta dissertação objetiva indicar áreas que apresentem maior prioridade de conservação para a promoção da sustentabilidade na Reserva Biológica da Contagem, que sofre forte pressão antrópica com crescimento populacional ao seu redor. Para isso foram utilizados modelos espaciais correlacionados com uma base de dados georreferenciados, aplicados em forma de mapas temáticos e combinados, gerando uma área final prioritária para a conservação. Um questionário foi realizado com um funcionário do órgão ambiental responsável pela gestão da Unidade de Conservação. Imagens aéreas e fotos do local foram registradas. As áreas com prioridades mais altas de conservação são compostas em sua maioria por espaços de vegetação natural, áreas com declividade do terreno mais acentuadas e regiões com maior fluxo de drenagens. As prioridades mais baixas são na maioria de uso antrópico, industrial ou áreas de solo exposto. As estratégias proposta para promoção da sustentabilidade são: a implantação de corredores ecológicos; construção de passagens inferiores de fauna; apoiar a criação de projetos de sustentabilidade e conservação da biodiversidade nas comunidades vizinhas, custeados por meio de compensações ambientais; reforçar a atuação de fiscalização nas áreas de APPs; delimitar zonas de amortecimento com atuação conjunta da população; ações para implementação de sistemas agroflorestais; incentivar o plantio de espécies nativas do cerrado nas casas próximas à Reserva; debater problemas com a comunidade e trabalhar a educação ambiental de forma lúdica; e abordar conteúdos relacionados à sustentabilidade nas escolas e capacitação de professores. Algumas de áreas de grande importância ambiental apresentaram-se como regiões de pouca prioridade de conservação, sendo necessários ajustes ou alterações na metodologia. Indica-se traçar estratégias e trabalhar com ações de sustentabilidade de curto, médio e longo prazos, e diante das dificuldades da legislação brasileira, adequar o sistema de gestão ambiental da área.

Palavras-chave: conservação da biodiversidade, estratégias de sustentabilidade ambiental, gestão ambiental, modelagem espacial. 


\begin{abstract}
This dissertation aims indicate areas that have greater priority for conservation to promote sustainability in the Biological Reserve of Contagem, suffering strong anthropic pressure with population growth around. For this were used spatial models correlated with a georeferenced database, applied and combined in form of thematic maps, generating a priority final area for conservation. A questionnaire was carried out with an official from the environmental agency responsible for managing the Conservation Unit. Aerial images and photos of the site were recorded. The areas with the highest priority conservation are composed mostly of areas of natural vegetation, areas with slopes of steeper terrain and regions with higher drainages flow. The lowest priorities are mostly anthropic use, industrial or bare soil areas. The proposed strategies for promoting sustainability are: the implementation of ecological corridors; constructions of underground fauna passages; support the creation of sustainability and biodiversity conservation projects at neighboring communities, financed through environmental compensation; strengthen supervise activities in the APPs areas; define buffer zones with joint efforts of the population; actions for the implementation of agroforestry systems; encourage the planting of native Cerrado species in houses nearby the reserve; discuss problems with the community and work the environmental education in a playful way; and to approach content related to sustainability in schools and teacher training. Some of the great environmental areas were presented as areas of low conservation priority, being necessary adjustments in methodology. It is indicated to plan strategies and work with short, medium and long-term sustainability actions, and face of the difficulties of Brazilian law suit the environmental management system of the area.
\end{abstract}

Keywords: biodiversity conservation, environmental sustainability strategies, environmental management, spatial modeling. 


\section{SUMÁRIO}

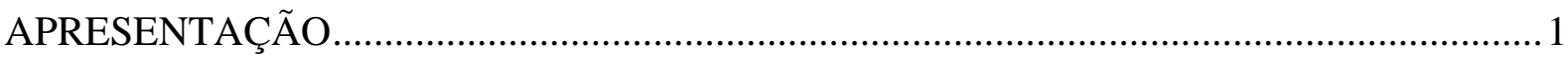

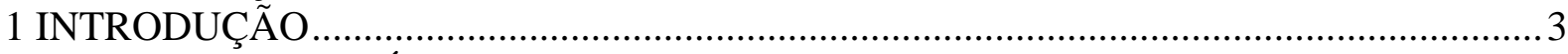

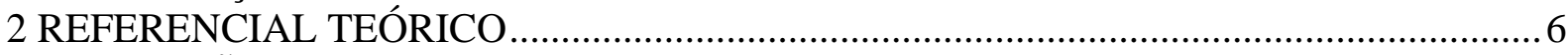

2.1 GESTÃO AMBIENTAL E TERRITORIAL ....................................................... 6

2.2 CONSERVAÇÃO DA BIODIVERSIDADE ........................................................... 14

2.3 UNIDADES DE CONSERVAÇÃO DA BIODIVERSIDADE NO BRASIL E NO

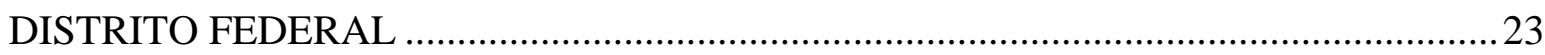

2.4 SUSTENTABILIDADE DE UNIDADES DE CONSERVAÇÃO .............................. 31

2.5 ESTRATÉGIAS PARA SUSTENTABILIDADE E A ANÁLISE ESPACIAL .............34

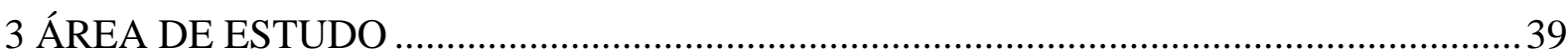

3.1 O CERRADO E AS OCUPAÇÕES URBANAS VIZINHAS À ÁREA DE ESTUDO 39

3.2 A RESERVA BIOLÓGICA DA CONTAGEM ........................................................ 40

3.2.1 CONFLITOS AMBIENTAIS NA REGIÃO DA REBIO DA CONTAGEM .........44

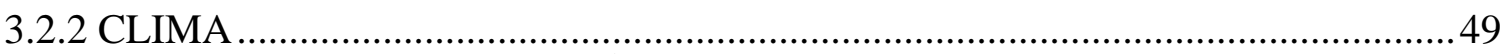

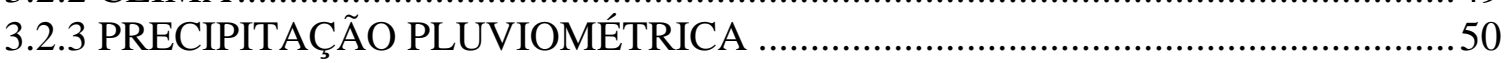

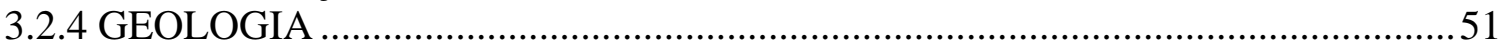

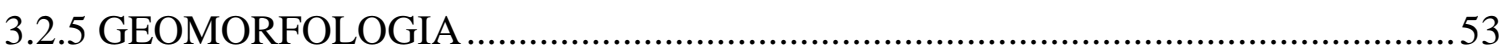

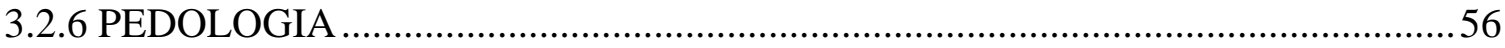

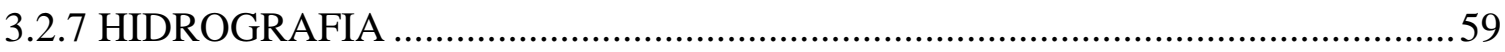

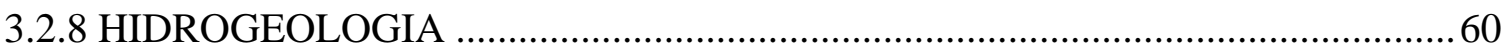

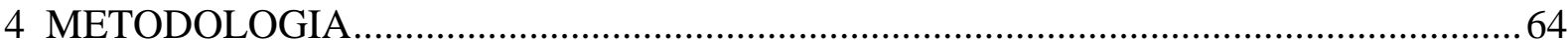

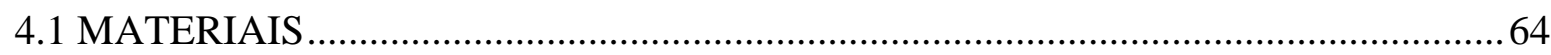

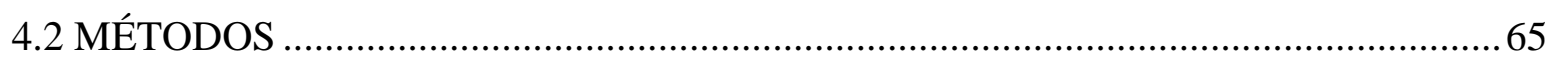

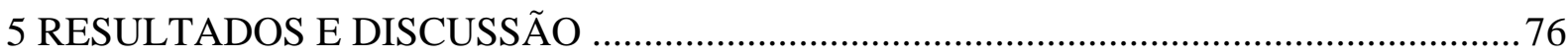

5.1 ÁREAS PRIORITÁRIAS DE CONSERVAÇÃ̃ ................................................... 95

5.2 A RESERVA BIOLÓGICA DA CONTAGEM E AS DIMENSÕES DA

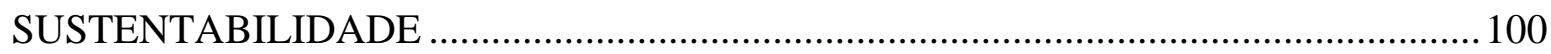

6. CONSIDERAÇÕES E RECOMENDAÇÕES FINAIS ................................................. 103

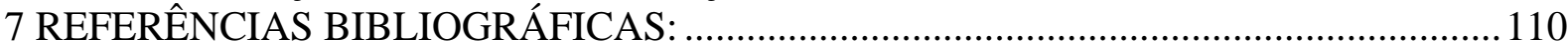

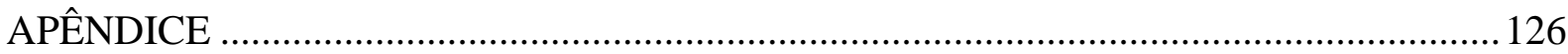




\section{APRESENTAÇÃO}

Os temas conservação ambiental e sustentabilidade têm se mostrado um importante foco de pesquisa da melhor doutrina brasileira e estrangeira. Isto porque tais temas são considerados chaves para a manutenção da biodiversidade e preservação de ecossistemas, mas a prática de ações capazes de fomentá-los não ocorre de forma tão simples e nem sempre com resultados eficientes.

Com vistas à preservação dos recursos naturais, da diversidade biológica e de ecossistemas, foram instituídas as Unidades de Conservação, que se caracterizam como áreas delimitadas pelo Poder Público para a conservação do meio ambiente. As Unidades de Conservação são áreas de grande valor biofísico, ecológico, geológico e bioquímico, fatores que são responsáveis pelo equilíbrio ambiental e pela manutenção da vida dos seres vivos na Terra.

Hoje, porém, é consabido que as Unidades de Conservação não garantem que os fatores acima mencionados estejam protegidos de modo uniforme e sustentável. Elementos externos a essas Unidades, provenientes de ações antrópicas, pressionam os espaços protegidos e influem em seus territórios, gerando consequências negativas para a manutenção dos mesmos e para reprodução de espécies.

Além disso, para contribuir com a proposta de conservação das áreas protegidas, é necessário dispor de um plano de manejo adequado, que contenha as prioridades na sua gestão e ações propostas para o gerenciamento da unidade, buscando a proteção do meio ambiente, a integração com as comunidades vizinhas por meio de uma conscientização ecológica, bem como possibilidades diferentes de otimização da unidade e administração geral de setores envolvidos e funcionários.

Mas a realidade atual da maioria das Unidades de Conservação é que, apesar de ser algo obrigatório, evidencia-se a falta de planos de manejo, de uma fiscalização mais enérgica, de recursos financeiros, de uma gestão ambiental mais eficiente e de ações sustentáveis, que, além de promoverem melhorias das condições ambientais nas áreas protegidas, também permitam o desenvolvimento de sua biodiversidade.

A Reserva Biológica da Contagem encontra-se neste contexto. A Unidade apresenta residências e fluxo constante de pessoas em seu interior, pressões antrópicas provenientes de 
comunidades vizinhas, não possui plano de manejo, apresenta deficiência de recursos para sua efetiva proteção, entre outros, sendo por isso escolhida como objeto de estudo.

Este trabalho é importante, pois busca identificar áreas da Reserva Biológica da Contagem e adjacências que apresentam um meio ambiente mais conservado, intocado e também áreas que apresentam níveis mais elevados de deterioração, contribuindo com diferentes propostas e prioridades de ações, conforme condições destacadas para as áreas analisadas. 


\section{INTRODUÇÃO}

O aumento da densidade populacional mundial e a modernização das sociedades têm demandado cada vez mais exploração de recursos e ocupação de áreas naturais para a sobrevivência da espécie humana, gerando grandes pressões que encurralam o meio ambiente, degradando-o progressivamente (ANDRADE, 2012).

Como exemplo dessa crescente ocupação no Brasil, é possível observar o caso do Distrito Federal (DF) que, apesar de seu processo de urbanização ser recente e vir se ampliando gradualmente, já exerce forte pressão sobre as fitofisionomias do cerrado, levando à formação de fragmentos de vegetação cada vez mais isolados e menores, o que interfere diretamente sobre a biodiversidade, sobre os recursos hídricos e consequentemente sobre a condição de vida da população do DF (IBRAM, 2014).

Embora a construção de Brasília tenha sido planejada, o seu rápido crescimento populacional ocorreu de modo descontrolado, superando a densidade demográfica de 500.000 habitantes estimada para o Distrito Federal no ano de 2000 e que foi atingida ainda no final da década de 1960 (MANCINI, 2008; BURSZTYN, 1997). O crescimento das cidades satélites ou regiões administrativas: cidades localizadas nas imediações da capital e que deveriam surgir após a consolidação completa da área metropolitana; se deu sem nenhum planejamento, o que contribuiu e ainda contribui para uma pressão excessiva sobre o meio ambiente (MANCINI, 2008; FERREIRA et al., 2012).

Esta pressão é uma das primeiras causas para o declínio da biodiversidade. De acordo com Geldmann, Joppa e Burguess (2014) a compreensão da extensão e dos efeitos das pressões humanas sobre o meio ambiente é essencial para a ciência da conservação, principalmente para que se possa analisar como essas pressões se comportam em relação às ações conservacionistas, se estas ações interferem positivamente para redução das pressões, se não apresentam interferência alguma sobre as mesmas, ou se interferem negativamente.

A fim de alcançar resultados que possibilitem mudanças nas pressões exercidas sobre o meio ambiente e que colaborem com o desenvolvimento da conservação da biodiversidade, de maneira sustentável, sem que o desenvolvimento seja privado de um padrão desejável de qualidade de vida para a humanidade, é que os estudos ambientais se tornam ferramentas importantes para a manutenção das Unidades de Conservação (UC). 
Os estudos ambientais são de grande valor para a conservação de áreas naturais, pois permitem contextualizar a situação atual das áreas de estudo extraindo informações importantes como o histórico da região; suas características-padrão de solo, vegetação, recursos presentes; suas espécies de fauna e flora, que compõem o habitat local; sua importância e função ecológica; e até o grau de impacto ambiental que as mesmas vêm sofrendo, bem como as consequências que tais impactos trazem ou podem vir a trazer para a região e para todo o ecossistema envolvido.

Quando tais estudos envolvem Unidades de Conservação, a magnitude de atuação dos mesmos apresenta resultados de maior relevância. Isso ocorre porque as regiões abrangidas nestas áreas protegidas podem conter exemplares de espécies-chave, espécies importantes para a manutenção do equilíbrio ecológico de um ecossistema; espécies raras e ameaçadas de extinção; ou espécies indicadoras de qualidade de habitat; ou, ainda, regiões de grande riqueza e abundância de recursos ou biodiversidade, responsáveis pelo equilíbrio ecológico, pela prospecção de espécies e pelo suporte de habitats (PRIMACK e RODRIGUES, 2001). Ocorre que muitas vezes, tais regiões encontram-se inseridas em meio a paisagens urbanas que interferem de forma negativa sobre as áreas de proteção ambiental.

De acordo com Geldmann, Joppa e Burguess (2014) as áreas protegidas sem classificação em alguma categoria de Unidade de Conservação apresentam maiores índices de pressão antrópica do que aquelas classificadas pela União Internacional para Conservação da Natureza (IUCN) , o que indica que as áreas categorizadas como UC's recebem mais atenção e cuidados que áreas sem uma liderança.

As UC's apresentam inúmeras vantagens ecossistêmicas que protegem recursos estratégicos para o desenvolvimento e qualidade de vida das populações (IBRAM, 2014). Entre estes recursos estão os bióticos, que incluem a riqueza de todos os tipos de seres vivos abrangidos em seus territórios, bem como a manutenção dos recursos físicos, químicos e minerais.

Dessa forma, quando as UC's sofrem pressões externas que interferem na qualidade ou quantidade de seus recursos abióticos, na sobrevivência e reprodução de suas espécies ou no microclima do local, entre outros, os danos são muito mais prejudiciais para o meio ambiente do que seriam se tais pressões fossem exercidas sobre áreas sem tamanha riqueza e desprovidas de benefícios essenciais à sobrevivência da humanidade e de todos os seres vivos, como ocorre com as UC's. 
Visando à proteção de áreas já demarcadas como Unidades de Conservação, mas que necessitam de gestão de qualidade e aplicações para o alcance de seus objetivos, este trabalho busca analisar as regiões e ocupações e sua interferência sobre a fragmentação ecológica da Unidade de Conservação, compreender a localização e atuação dessas ocupações é de fundamental importância para criar estratégias de sustentabilidade e conservação no local.

Em busca de propor melhorias para as condições ambientais da Reserva, da conservação e de sua relação com a população vizinha, este trabalho tem como:

- Objetivo geral: indicar áreas prioritárias de conservação da Reserva Biológica da Contagem, tanto no viés da preservação, como no da atuação da gestão ambiental.

- Objetivos específicos:

- Destacar importantes componentes de valor ecológico na área de estudo por meio de critérios de prioridade.

- Propor estratégias de atuação para a promoção da sustentabilidade da Reserva Biológica da Contagem. 


\section{REFERENCIAL TEÓRICO}

\subsection{GESTÃO AMBIENTAL E TERRITORIAL}

O tema gestão ambiental tem atraído a atenção de governos e empresas que buscam implementar políticas estratégicas para que atividades desenvolvidas com a utilização de recursos ambientais ou que possam gerar resultados que interfiram sobre os mesmos, se adequem às limitações do meio ambiente e à preservação de ecossistemas.

Para melhor abordagem sobre este tema é importante compreender o contexto de interpretação da gestão ambiental como sendo a integração entre o planejamento, a política e o gerenciamento ambiental (SANTOS, 2004).

O planejamento ambiental, que desde anos de 1930 teve como base do planejamento os recursos hídricos, surgiu da necessidade de organização do uso da terra com a manutenção da qualidade de vida das populações e também do meio ambiente, e se mostra um instrumento voltado a solucionar embates que porventura possam ocorrer entre as metas da conservação ambiental e do planejamento tecnológico, ou seja, visa integrar informações, diagnosticar o ambiente, prever ações e normatizar o uso da terra, exigindo uma abordagem holística de análise e aplicação (SANTOS, 2004). Em outras palavras:

\footnotetext{
O planejamento ambiental consiste na adequação de ações à potencialidade, vocação local e à sua capacidade de suporte, buscando o desenvolvimento harmônico da região e a manutenção da qualidade do ambiente físico, biológico e social (SANTOS, 2004, p. 28).
}

Para estabelecer um planejamento ambiental é necessária toda uma estruturação dividida em etapas: primeiramente são definidas metas do que se pretende alcançar a médio e longo prazo, em seguida os objetivos específicos para alcance de sua realização. Nesta etapa são definidos os meios de implementação, é delimitada a área de estudo, que envolve a magnitude de ação; também é estruturado um banco de dados com as informações pertinentes da área e são selecionados indicadores ambientais e as escalas de trabalho. Na sequência a etapa do diagnóstico onde os dados são analisados, após esta etapa são identificadas alternativas para a solução dos problemas levantados e cumprimento das metas, são então tomadas decisões e escolhidas as melhores opções para a implementação do planejamento ambiental. Após 
implementação vem a etapa de monitoramento e avaliação, para verificar se os resultados estão sendo alcançados ou se são necessários ajustes no planejamento (FIDALGO, 2003; SANTOS, 2004).

A política ambiental consiste nos princípios doutrinários e intenções que condizem com as pretensões sociais e/ou governamentais referentes à proteção do meio ambiente, sua conservação, controle e regulamentação ou modificação. Já o gerenciamento ambiental se refere ao conjunto de ações designadas para estes mesmos fins. $\mathrm{O}$ gerenciamento também verifica se a atual situação está de acordo com os princípios determinados pela política ambiental (LANNA, 2000).

Entre os fatos que marcaram a necessidade de implantação de sistemas de gestão ambiental, podemos citar entre os mais impactantes as mudanças ocorridas com a potencialização da industrialização, que teve início na Grã-Bretanha ainda o século XVIII, e difundiu-se pela Europa no século XIX (CAMPOS, 2001). No Brasil, a Revolução Industrial teve início na década de 1930 e proporcionou um grande movimento de migração das populações rurais para as grandes cidades devido à oferta de emprego (SILVA \& FRANCISCHETT, 2012).

A utilização de máquinas possibilitou a implantação de novas técnicas de produção, gerando um crescimento na produção em larga escala, elevando assim o índice de consumo de bens e produtos industrializados. Essa realidade demandou um aumento na utilização de recursos naturais, além de problemas com a poluição ocasionados pelo setor industrial e pela geração de resíduos. Isto agravou a situação de impacto sobre o meio ambiente, que não consegue se recompor na mesma medida que é explorado e deteriorado (SILVA \& FRANCISCHETT, 2012).

Além das consequências advindas da industrialização, a globalização da economia, o aumento da população mundial e o advento de novas tecnologias voltadas à exploração de recursos colocaram o meio ambiente como um fator de extrema importância para qualquer organização.

Outro fator que também contribuiu para a percepção da necessidade de uma gestão ambiental foi o aprimoramento da qualidade de produtos e serviços oferecidos pelas empresas. Com o aumento da competitividade e do consumo, tornou-se necessário baixar os custos e aumentar a produtividade, melhorando o gerenciamento e o desenvolvimento das organizações. A questão da produção com qualidade e eficiência se mostrou um fator diferencial no mercado. 
Ainda sobre esse tema, sublinhe-se que na década de 1950 e 1960 o Japão implantou o Controle Estatístico da Qualidade (SQC) e a filosofia do Controle de Qualidade Total (TQC) em seus produtos, conseguindo destaque entre outros produtos internacionais no mercado. Vinte anos depois, os Estados Unidos adotaram a filosofia de Gerenciamento da Qualidade Total (TQM) e assumiram uma ideia mais sistêmica de gerenciar todos os aspectos qualitativos envolvidos. Esta filosofia foi a precursora dos sistemas de gestão da qualidade, como as normas do conjunto ISO 9000, que teve grande influência sobre as normas britânicas de gestão ambiental (CAMPOS, 2001).

A partir da década de 1970 surgiram os primeiros estudos de avaliação dos impactos ambientais e diversos documentos de cunho ambiental foram elaborados. Como exemplo, podem ser citados o Relatório do Clube de Roma, Os Limites do Crescimento, o Relatório de Brundtland, a Declaração do Rio sobre Meio Ambiente e Desenvolvimento, a Agenda 21, os quais serão mais detalhados no tópico sobre sustentabilidade. Ressalte-se, no entanto, que esses documentos demonstram como é importante um gerenciamento que se volte para o desenvolvimento com enfoque de responsabilidade para a manutenção ambiental.

A temática gestão ambiental teve início como objeto de pesquisa a partir da década de 1980, mas veio a se destacar apenas no final dos anos de 1990. Foi inicialmente fundamentada no setor privado, principalmente no âmbito jurídico administrativo, vindo posteriormente a ser aplicada no setor público por meio de políticas públicas (LIMA, 2001).

De acordo com Barbieri (2007), o processo de transformação da gestão ambiental pode ser dividido em fases, sendo a primeira compreendida do início do século XX até 1972, período em que as questões ambientais eram abordadas de modo pontual, porém desvinculadas dos processos de desenvolvimento. A segunda fase, que vai de 1972 até 1992, é caracterizada por um período que busca uma nova relação entre meio ambiente e o desenvolvimento. Na terceira fase, compreendida a partir de 1992 até os dias atuais, a gestão ambiental é marcada por uma abordagem de desenvolvimento de modo sustentável.

Para Godard (2002) a gestão passou a ser inserida em todas as áreas que compõem os aspectos ambientais. Ela estabelece o centro entre contradições e conciliações de alvos que visam à conservação do meio ambiente e manutenção da qualidade ambiental. Bursztyn (1994) ressalta a importância da implantação de estratégias preventivas para o meio ambiente, pois é muito mais viável prevenir danos ambientais a remediá-los, tanto no plano ambiental como também no econômico. Para isso são necessárias ações de gestão desde o instante de 
elaboração de políticas públicas pelo setor público, como também pelo setor privado, quando da exploração de recursos naturais.

Buscando-se uma padronização dessas políticas voltadas para o meio ambiente e que pudessem atender aos mais diversos setores que lidam com esta vertente, ainda nos anos de 1990 foram desenvolvidos Sistemas de Gestão Ambiental (SGA), com a função de conduzir empresas na adequação de normas padrão, a fim de sistematizar procedimentos com vistas à qualidade ambiental e à conservação de recursos naturais (NICOLELLA, MARQUES e SKORUPA, 2004).

Em 1992, o Reino Unido, por meio da British Standard Institution (BSI), criou um conjunto de normas que estabeleceram um SGA voltado para as empresas do país: a norma britânica BS 7750 - Specification for Environmental Management Systems (Especificação para Sistemas de Gerenciamento Ambiental). Esta norma entrou em vigor em 1994 e serviu de base para a criação das normas ambientais da série ISO 14000, um conjunto de normas que fornece ferramentas para a padronização de Sistemas de Gestão Ambiental, entre elas a ISO 14001, que apresenta diretrizes de básicas para o desenvolvimento de um SGA (NICOLELLA, MARQUES e SKORUPA, 2004; Souza et. al., 2012).

Além dessas várias normas e princípios, foram criados outros no âmbito empresarial, que levaram à formulação de sistemas de gestão ambiental, sendo alguns de maior destaque representados no Quadro 1:

Quadro 1. Quadro resumo dos sistemas e princípios de gestão ambiental.

\begin{tabular}{|c|c|l|l|}
\hline Norma ou princípio & Ano & \multicolumn{1}{|c|}{ Principais características } & \multicolumn{1}{|c|}{$\begin{array}{c}\text { Certificável/Não } \\
\text { Certificável }\end{array}$} \\
\hline $\begin{array}{c}\text { Responsible Care }{ }^{\circledR} \\
\text { Program }\end{array}$ & 1984 & $\begin{array}{l}\text { Consiste de princípios diretivos, seis } \\
\text { códigos de práticas gerenciais, painel } \\
\text { público consultivo e grupos de liderança }\end{array}$ & $\begin{array}{l}\text { Voluntário, não certificável. } \\
\text { Exigido pelos membros da } \\
\text { Chemical Manufactures } \\
\text { Association. No Brasil é } \\
\text { coordenado pela ABIQUIM, } \\
\text { desde 1990 }\end{array}$ \\
\hline Modelo Winter & 1989 & $\begin{array}{l}\text { Vinte módulos integrados visando facilitar } \\
\text { a implementação do SGA }\end{array}$ & Voluntário, não certificável \\
\hline CERES & 1989 & $\begin{array}{l}\text { Consiste em dez princípios diretivos que } \\
\text { enfatizam a necessidade das organizações } \\
\text { de proteger o planeta e agir } \\
\text { responsavelmente em relação ao meio } \\
\text { ambiente }\end{array}$ & Voluntário, não certificável \\
\hline STEP & 1990 & $\begin{array}{l}\text { Guia para a indústria de petróleo americana } \\
\text { que possibilitasse um aprimoramento de sua } \\
\text { performance ambiental, saúde e segurança }\end{array}$ & Voluntário, não certificável \\
\hline EMAS & 1993 & $\begin{array}{l}\text { Sistema que permite às indústrias da } \\
\text { Comunidade Européia obter um registro }\end{array}$ & $\begin{array}{l}\text { Certificável através publicação } \\
\text { no jornal oficial da União }\end{array}$ \\
\hline
\end{tabular}




\begin{tabular}{|c|c|l|l|}
\hline & & $\begin{array}{l}\text { publicado no jornal oficial da União } \\
\text { Européia }\end{array}$ & Européia \\
\hline BS 7750 & 1994 & $\begin{array}{l}\text { Especificação para o desenvolvimento, } \\
\text { implementação e manutenção de um SGA } \\
\text { para assegurar e demonstrar conformidade } \\
\text { com as declarações da empresa quanto à } \\
\text { política, objetivos e metas ambientais }\end{array}$ & Certificável \\
\hline ISO 14001 & 1996 & $\begin{array}{l}\text { Norma ambiental internacional que } \\
\text { especifica os requisitos relativos a um SGA, } \\
\text { permitindo à organização formular sua } \\
\text { política e objetivos que levem em conta os } \\
\text { requisitos legais e informações referentes } \\
\text { aos impactos ambientais significativos }\end{array}$ & Certificável \\
\hline ISO 14004 & 1996 & $\begin{array}{l}\text { Guia de diretrizes para a Norma ambiental } \\
\text { internacional ISO 14001 que especifica os } \\
\text { requisitos relativos a um SGA }\end{array}$ & Diretrizes, não certificável \\
\hline
\end{tabular}

Fonte: Neto, Campos e Shigunov (2009) p. 164 - 165 (adaptado de Campos, 2001)

A gestão ambiental para Castro (1995) é uma maneira de intervir sobre uma específica área ambiental, trazendo melhorias ao meio ambiente por intermédio de políticas e estratégias. O termo gestão ambiental para Neto, Campos e Shigunov (2009), pode ser definido como o conjunto de atividades da função gerencial que determinam a política ambiental, os objetivos, as responsabilidades e que são postos em prática através do sistema ambiental, do planejamento, do controle e da melhoria do gerenciamento ambientais.

Barbieri (2007) define a gestão ambiental como instruções e atividades executadas no âmbito administrativo e operacional, que buscam reduzir, extinguir ou evitar os resultados negativos sobre o meio ambiente, decorrentes de ações humanas, para assim se obter mais efeitos positivos sobre ele.

De acordo com a Norma Brasileira ISO 14001 (ABNT, 2004), o Sistema de Gestão Ambiental é parte de um sistema da gestão de uma organização utilizada para desenvolver e implementar sua política ambiental e para gerenciar seus aspectos ambientais.

Para o SEBRAE/MMA (2007), como o mecanismo de controle que integra um conjunto de procedimentos e instruções que são usados para o gerenciamento e administração de uma organização com o objetivo de estabelecer a melhor relação possível com o meio ambiente. Conforme Gilbert (1995) o principal objetivo de um SGA é promover uma melhoria do desempenho ambiental continuadamente através de um controle sistemático.

Conforme exposto é essencial que haja uma organização e que se trabalhe em prol de administrar as relações que envolvam o meio ambiente de modo a cooperar para a manutenção e melhoria deste. No Brasil, as Unidades de Conservação representam as entidades, sob 
responsabilidade do poder público, responsáveis por abrigar áreas naturais ricas em biodiversidade, que necessitam de diretrizes para o gerenciamento de suas áreas e ecossistemas.

Nos últimos anos, a política ambiental vem ganhando espaço no território brasileiro, como exemplos da política voltada para gestão ambiental federal podem ser citados: a Lei de Crimes Ambientais, Lei das Águas, Política Nacional de Educação Ambiental, Lei que constituí a Política Nacional de Meio Ambiente, Lei que instituiu o Sistema Nacional de Unidades de Conservação da Natureza - SNUC, entre outros, e diversos são os órgãos da esfera federal que têm como objetivos a proteção ao meio ambiente: CONAMA, FNMA, IBAMA, ICMBIO, ANA, entre outros (BRASIL 2002a).

A implantação de um SGA numa Unidade de Conservação permite que a equipe gestora da unidade tenha conhecimento sobre os pontos de conflito entre seus objetivos e a prática, permite também definir programas com objetivos e metas específicos para controle dos aspectos ambientais mais importantes, previne impactos negativos ao ambiente, além de estabelecer metas ambientais com o intuito de harmonizar as funções da Unidade de Conservação (UC) com as necessidades de conservação e preservação do bioma caracterizado em sua região (BRASIL, 2007).

Para Gilbert (1995), Sistemas de gestão ambiental são extremamente importantes até para verificar se as UC's estão realmente cumprindo com os objetivos para os quais foram criadas e assim garantir melhoria em seu gerenciamento. De acordo com o BRASIL (2002a), as atividades previstas no Plano de Manejo da UC podem ser controladas e em caso de inviabilidade das mesmas, medidas alternativas podem ser tomadas para redirecionar os meios e atingir os objetivos.

Referindo-se ao tema de gestão ambiental também se faz necessário abordar a gestão territorial, no qual o universo ambiental está contido, que busca propor modelos de gerenciamento do território.

A gestão territorial serve para ordenar os processos de desenvolvimento designando os papéis dos responsáveis na atuação da gestão, promovendo a articulação de instrumentos público e privados, influindo na distribuição e uso do poder no domínio de um dado território, entre outros (DUNCAN, 2015). Para melhor compreender a atuação da gestão, se faz necessário entender o significado de território. A palavra território apresenta diferentes concepções de acordo com a perspectiva e área de conhecimento dos autores que o define. Como diz DUCAN: 
Desde a década de 1970, o conceito de território é debatido em diversos campos do conhecimento como a geografia, abrangendo a territorialização das atividades humanas e do poder; sociologia, examinando a construção e funcionamento dos espaços urbano e rural; a economia, cujos aspectos mais relevantes seriam os efeitos econômicos da localização da produção; a antropologia, focalizando principalmente a cultura e a relação entre o mundo material e o simbólico; a política, sob a ótica do poder e da cultura política; a psicologia, com elementos como o sentido do pertencimento e solidariedade; nas empresas, como estratégia para constituir capacidade competitiva; além de campos interdisciplinares, tais como o desenvolvimento, a criminologia e a governança. (DUNCAN, 2015)

O território se forma a partir do espaço, de sua ocupação e transformação que geram relações orientadas pelo poder (RAFFESTIN, 1993). No Estado essas relações de poder são gerenciadas pelo governo através de leis e políticas em âmbito nacional, regional, estadual e municipal que obrigam o cumprimento de normas e padrões a serem exercidos por todos os cidadãos, assim, como o cumprimento da fiscalização em prol do desenvolvimento, ordenamento e manutenção do país. Esse papel do Estado em exercício de sua soberania e estruturação de seu progresso é executado por meio da gestão territorial.

A concepção da gestão ambiental no Estado se tornou um aspecto de maior importância e abrangência nas últimas décadas, com o fortalecimento das visões ambientalistas e a crescente necessidade do desenvolvimento de atitudes sustentáveis e conservadoras do meio, novas políticas foram criadas em prol de uma melhoria na administração das questões ambientais.

É possível verificar isto na própria Constituição de 1988 em seu título VIII, que trata do ordenamento social e apresenta com exclusividade em seu capítulo VI o tópico meio ambiente, que traz uma abordagem da sustentabilidade como um direito de todos, sob defesa do Poder Público e preservação para as gerações futuras. Além de falar a respeito de manejo ecológico de espécies e ecossistemas, preservação de patrimônio genético, proteção à fauna e flora, promoção à educação ambiental, definição de espaços especialmente protegidos e questões relacionadas a impactos ambientais e recuperação de ambientes degradados (BRASIL, 1988). Neste trabalho, o conceito de território abordado será baseado conforme a visão da Constituição Federal, no território governamental estabelecido.

A gestão territorial abrange os aspectos que compõem a estruturação do país, porém como o território possui uma relação de identidade social e cultural com cada espaço local correspondente (ITABORAHY, 2010) a gestão não pode ser exercida de modo único e central, o próprio Estado distribui suas atribuições nas esferas de governo, a fim de ter um controle 
mais eficaz e pontual de cada estado ou município (BRASIL, 1988, Art 23) integrando políticas públicas num determinado território, ampliando assim as possibilidades de decisões políticas mais eficientes.

Essas diferenças locais exigem diferentes planejamentos de gestão territorial, que mesmo trabalhando no viés da questão ambiental também abrangem outros aspectos e que variam conforme a região: a realidade social, cultural, econômica de uma região, a educação ambiental que tem acesso a população local, assim como o grau de instrução da mesma, a dimensão territorial ambiental, a biodiversidade, o grau de conservação do meio ambiente, as verbas governamentais, os órgãos fiscalizadores e a própria gestão local, o tipo de bioma, os diferentes meios de exploração, os diferentes recursos de cada área, o nível de poluição, entre outros fatores.

Para Godard (2002), a gestão ambiental tem início em recursos naturais específicos, e vai ganhando abrangência para espaços naturais e ecossistemas, até ser retratada como gestão territorial com participação do governo e comunidades locais. Dessa forma a gestão passa a ser conceituada como integrada, onde as relações ambientais são inseridas em meio aos propósitos de desenvolvimento econômico, adquirindo assim um enfoque mais estratégico de desenvolvimento, onde os interesses ambientais se aliam aos sociais.

Ainda segundo Godard (2002), vários fatores se fazem necessários para que a gestão ambiental seja viabilizada, como: integrar o gerenciamento dos recursos naturais ao desenvolvimento do território, a participação ativa da sociedade na gestão, a criação de entidades com objetivos pontuais e plurais, a descentralização gerencial e a gestão territorial que abrange o maior número dessas interações.

É cada vez maior a busca por parte de governos e empresas de implementar políticas estratégicas para que atividades desenvolvidas, que se utilizem de recursos ambientais ou que possam gerar resultados que interfiram sobre os mesmos, se adequem às limitações do meio ambiente e à preservação de ecossistemas.

Assim, a gestão territorial busca colocar em ordem as atividades humanas de acordo com diretrizes que instruem projetos, programas e planos institucionais e governamentais, condizentes com o meio e através do planejamento ambiental são selecionados dados mais objetivos, representativos, que cumpram papel de indicadores ambientais, esses indicadores funcionam como representantes de maior relevância para a conservação ambiental e de embasamento para as propostas de gerenciamento. 
Uma maneira de tornar mais fácil a execução de um planejamento ambiental é fazer uso de ferramentas de classificação e avaliação das paisagens, como a delimitação de unidades de paisagem. As unidades de paisagens são áreas relativamente homogêneas que se distinguem pelo relevo, clima, cobertura vegetal, solos, litologia ou por apenas um desses elementos (ROSS, 1991). São áreas que denotam a estreita relação entre as características ecológicas e antrópicas de um território, sendo assim, o estudo da paisagem necessita de uma metodologia de discernimento e classificação apoiada numa escala temporo-espacial (BERTRAND, 2004).

A paisagem é descrita por Bertrand (2004) como um espaço composto por elementos físicos, biológicos e antrópicos, que se combinam de modo dinâmico e instável, que em atuação dialética formam um conjunto geográfico indissociável em evolução. Para Christofoletti (1998) a compreensão do espaço como um sistema ambiental, físico e socioeconômico, onde os elementos físicos, biogeográficos, sociais e econômicos são estruturados é proporcionado pela paisagem.

A interação das unidades de paisagem determinam a estrutura fundamental da paisagem e uma compreensão mais holística que é utilizada de acordo com os objetivos do planejamento ambiental, pela adoção de medidas e estratégias de intervenção. Pesquisas que buscam compreender o funcionamento da paisagem por meio dessa homogeneidade podem configurar um método mais humano, interativo, consensual, rápido e simples, auxiliando nas melhores escolhas para o uso e ocupação da terra, pois por meio das unidades de paisagem é possível identificar os atributos responsáveis pela dinâmica da paisagem e suas fragilidades ambientais, que são indispensáveis para interpretação do território e intervenção de um trabalho de gestão territorial (AMORIM e OLIVEIRA, 2008).

\subsection{CONSERVAÇÃO DA BIODIVERSIDADE}

A natureza fornece tudo o que os seres humanos necessitam para sobreviver. Fornece desde o ar que é o principal elemento para a sobrevivência da espécie, fornece água, fonte da vida e composição principal da constituição corpórea, fornece alimento para a sua nutrição e fonte de energia, terra para produção, abrigo e fornecimento de matérias-primas, uma atmosfera que garante temperaturas amenas que climatizam o ambiente e proporcionam condições adequadas para a sobrevivência, fornece a ciclagem de elementos vitais que garantem a 
perpetuação da espécie, até as relações ecológicas que possibilitam assim a subsistência no planeta Terra e os recursos que utilizamos para construir, extrair ou produzir benefícios para uma melhor qualidade de vida.

Em outras palavras, a natureza é a base de toda a existência humana e também a base da economia, pois dela são provenientes os recursos e matérias-primas que movimentam os mercados em todo o mundo. Tamanha variedade de recursos compreende uma riqueza enorme de espécies de flora e fauna a qual chamamos de biodiversidade e esta vem sendo progressivamente atacada pelo homem que cria, cada vez mais, uma dependência de exploração maior da natureza para o suprimento de suas necessidades básicas e supérfluas (PRIMACK e RODRIGUES, 2001).

O Brasil é um país extremamente rico em biodiversidade e juntamente com a Indonésia são os países que possuem maiores diversidade de espécies, sendo a do Brasil a maior do planeta (MITTERMEIER et.al. 2005). De toda a biodiversidade mundial, cerca de 1.500 .000 espécies de plantas e animais (RICKLEFS, 2010), dois terços se concentram nos trópicos, com 37\% dela na América Tropical.

O Brasil possui cerca de $20 \%$ de toda a biodiversidade atualmente conhecida da Terra, sendo este número muito maior, porém ainda desconhecido. Esta biodiversidade compreende espécies de fauna e flora endêmicas. O Brasil possui ainda o maior sistema fluvial do mundo e abrange cinco grandes biomas ao longo de toda a extensão do seu território de mais de 8,5 milhões de $\mathrm{km}^{2}$, o quinto maior dentre os territórios no mundo (Brandon et al., 2005; VILELAMORALES \& VALOIS, 2000).

A diversidade biológica ou biodiversidade é o termo que se refere à variedade de vida no planeta (PRIMACK e RODRIGUES, 2001). O termo diversidade biológica foi citado inicialmente no ano de 1968, pelo cientista e conservacionista Raymond F. Dasmann, mas somente na década de 1980 que seu uso começou a ganhar espaço na ciência e se popularizar (FRANCO, 2013).

A Convenção sobre Diversidade Biológica (CDB) define a diversidade biológica como:

A variabilidade de organismos vivos de todas as origens, compreendendo, dentre outros, os ecossistemas terrestres, marinhos e outros ecossistemas aquáticos e os complexos ecológicos de que fazem parte; compreendendo ainda a diversidade dentro de espécies, entre espécies e de ecossistemas. (BRASIL, 2000, Artigo 2, p. 9) 
Dessa forma a biodiversidade é composta em três níveis: a diversidade genética referente à variação de genes encontrados nas espécies, a diversidade de espécies que inclui todos os organismos vivos e a diversidade de ecossistemas que inclui as comunidades biológicas, suas relações e os lugares onde vivem (PRIMACK e RODRIGUES, 2001).

É essa riqueza de diversidades que garante a existência do meio ambiente em que vivemos. A biodiversidade também contribui para a agricultura através do controle de pestes e da polinização, promove o sequestro de carbono da atmosfera, manutenção do oxigênio, da umidade, dos ventos, da precipitação, conservação dos solos, resiliência contra distúrbios e mudanças ambientais, controle de predadores, fornece bens materiais como madeira, medicamentos, fibra, é fonte de recursos para fins econômicos, industriais, culturais, turísticos, recreativos, científicos, terapêuticos, espirituais (TUNDISI e MATSUMURA-TUNDISI, 2008; GANEM, 2007; RANDS et al., 2010) entre tantos outros.

Embora a biodiversidade apresente inúmeros benefícios e importância para a humanidade, ela vem sendo reduzida progressivamente ao longo dos anos. A intervenção do homem sobre o meio ambiente através da exploração abusiva de seus recursos e ocupação do solo, provoca impactos diretos aos ecossistemas e acarreta consequências severas para a diversidade biológica.

Várias são as circunstâncias que ameaçam a biodiversidade, como a superexploração de espécies, a invasão de espécies exóticas, a poluição hídrica, dos solos, do ar, as mudanças climáticas e de regimes hídricos, esgotamento e contaminação de recursos, o crescimento da urbanização e principalmente a fragmentação e a degradação de habitats (RANDS et al., 2010;).

As pressões humanas são muitas e aparecem por todos os lados, dentre as quais o desmatamento de terras para o cultivo agrícola e o uso de pesticidas no mesmo; o comércio de madeira ilegal e insustentável; a captação excessiva de água para a agricultura, indústria e uso doméstico que geram pressão sobre os recursos hídricos; a salinização do solo, decorrente de irrigações incorretas ou captação de água em regiões áridas, que geram perda de vegetais cultivados, solos agricultáveis e elevam a possibilidade de desertificação; práticas de mineração; atuação sobre o regime de fogo; excesso no consumo de óleos vegetais para alimentação, cosméticos, biocombustíveis que aumenta o plantio em terras tropicais úmidas; exploração excessiva de proteína marinha focada em peixes no topo da cadeia alimentar; aquicultura mal gerida; destruição do habitat costeiro; aumento de $\mathrm{CO} 2$ na atmosfera ameaça 
aos corais pela acidificação dos oceanos; entre vários outros fatores (RANDS et al., 2010; RODRIGUES, 2002).

Conforme citado em Brito (2004), foi a partir da década de 1960 que a biologia da conservação começou a aparecer, mas foi na década de 1980 que ela realmente ganhou espaço, apoiada em fundamentos da ecologia e das ciências naturais, que dão a ela um caráter de ciência multidisciplinar.

Os anos de 1985 a 1988 foram muito importantes para a afirmação da biologia da conservação, sendo que o ano de 1985 tem destaque pela Segunda Conferência Internacional sobre Biologia de Conservação, que teve como resultado a fundação da Sociedade para a Biologia da Conservação (SCB) e por trabalhos de Michael E. Soulé que definiram a biologia da conservação como uma disciplina guiada por um senso de missão ou de crise, com objetivo de fornecer os princípios e as ferramentas necessárias para garantir a conservação da diversidade biológica e na qual muitas vezes é necessário agir antes de se ter uma confiança absoluta nos dados, pois os riscos de nenhuma ação, em geral, são maiores do que os da ação inadequada (FRANCO, 2013).

Nos países tropicais, que apresentam maiores concentrações de biodiversidade, essa perda é maior, isso é perceptível no Brasil onde se encontram os biomas mais ameaçados do planeta (GANEM, 2007).

Até o ano de 2008 o Cerrado já havia perdido mais de $48 \%$ de sua cobertura original (MMA/IBAMA/PNUD, 2009). Em razão deste fato, foi categorizado como um hotspot, áreas caracterizadas por alta concentração de espécies endêmicas e que tiveram grande perda de seu habitat (MYERS et al., 2000). No Cerrado são encontradas quase 20\% das espécies brasileiras e levando-se em conta o grupo taxionômico corresponde a uma porcentagem de 20 a $50 \%$ das espécies (MACHADO, 2004).

A redução da área de cobertura da vegetação ocasiona a fragmentação de habitats e isto leva à extinção de espécies, que pode ser a maior perda que a biodiversidade pode sofrer, pois se uma espécie tem seu número de indivíduos reduzidos, ainda é possível repovoá-la porque ainda existe o banco genético, se uma espécie se encontra isolada ela pode recuperar o potencial de sua variação genética através da mutação, seleção natural e recombinação. Porém, a extinção acarreta perda da informação gênica, que é única, isto empobrece as comunidades biológicas das quais a espécie extinta faz parte (BRAGA, 2010).

A extinção faz parte da natureza evolutiva dos seres vivos e ao longo de bilhões de anos e ciclos pelos quais a Terra passou houve a extinção e o surgimento de diversas espécies. O que 
preocupa a comunidade conservacionista, entretanto, é o ritmo em que a perda vem ocorrendo. Apesar de este ser o período geológico de maior grau de diversidade biológica (PRIMACK e RODRIGUES, 2001) e de não se saber exatamente o número de espécies que existem no planeta, os números de extinção são alarmantes, dados de Sepkoski (2001) estimam a perda de 5 a 100 espécies diariamente, porém, conforme citado por Ganem (2007) este dado pode ser pior, de 50 a 250 espécies por dia.

De fato a intervenção humana sobre o meio ambiente tem gerado amplas alterações na paisagem causando um desequilíbrio nos ecossistemas muito além da dinâmica natural de perturbação e embora a extinção seja um processo natural, todas as de vertebrados que ocorrem atualmente são atribuídas às atividades humanas e também grande parte das extinções de invertebrados (RODRIGUES, 2002).

O assunto tornou-se tão problemático que o tema foi ganhando mais e mais atenção, principalmente nos últimos anos devido à amplitude de seus resultados na realidade global e na velocidade com que esta foi atingida, que ganhou espaço nas publicações de importantes jornais científicos sobre a conservação da biodiversidade.

Como se pode ver em Velasco et al. (2015) que analisou a tendência do conhecimento científico em três jornais internacionais (Biodiversity \& Conservation, Biological Conservation e Conservation Biology) nos anos de 2000 e 2011, observando, entre outros, aspectos o tipo de pesquisa e seu principal tópico e o componente da biodiversidade que foi objeto de estudo e suas características e as pressões e determinantes. Entre os resultados obtidos podem ser citados o aumento nas pesquisas sobre extinção de espécies e desenvolvimento de estratégias de manejo do ano 2000 para 2011; o assunto mais abordado em 2000 era distribuição de espécies e biogeografia, seguido pelas espécies ameaçadas de extinção, já em 2011 o principal foi o desenvolvimento de estratégias de manejo; o número de trabalhos de literatura foi abaixo do esperado para a América do Sul em 2000 e 2011; e 5\% dos trabalhos focam sobre tópicos sociais, o que deveria ter uma porcentagem maior, tendo em vista que os impactos sobre a natureza são resultados de comportamentos humanos, que envolvem e determinam escolhas de conservação ou exploração da natureza.

A fragmentação de habitats é um tópico que apresenta destaque na perda da biodiversidade e tem entre suas principais causas a redução na área total das florestas que são degradadas para dar espaço às plantações, monoculturas, pastagens e para o desenvolvimento industrial, agrícola, urbano e o crescimento econômico de uma região (MMA/SBF, 2003). Ela é caracterizada pela redução de grandes espaços de habitat em fragmentos menores. 
Com o rompimento da continuidade do habitat ou a redução de sua área, a paisagem sofre modificações formando manchas de vegetações remanescentes que se isolam umas das outras. Este isolamento provoca uma série de consequências aos processos ecológicos que diminuem a riqueza e a qualidade do ambiente, deteriorando-o e afetando as comunidades biológicas em diversos aspectos, sobretudo o aspecto gênico.

Quando o isolamento acontece o fragmento acaba tornando-se como uma ilha, sem contato com outras. Este isolamento acaba limitando a área de vida de espécies que muitas vezes necessitam de maiores espaços para transitar, procurar alimentos e recursos, se reproduzirem, ou que possuem hábitos sazonais migratórios ou de acordo com variações climáticas.

No caso de espécies sensíveis a alterações ambientais, ou de distribuição restrita ou pouco abundantes, ou espécies endêmicas, a influência sobre as mesmas é ainda pior, pois estas necessitam de áreas mais intactas para sua sobrevivência. A fragmentação de habitats também limita a dispersão de animais e a colonização de regiões, isto afeta as populações em outros aspectos, como o aumento da competição por habitats e dificuldade de dispersão de sementes (LAURANCE et al., 2011; PRIMACK e RODRIGUES, 2001).

Outra consequência que a fragmentação de habitats acarreta é o chamado efeito de borda, que muitas vezes domina a dinâmica dos fragmentos, ele altera a composição e/ou a abundância de espécies na margem dos mesmos (LAURANCE et al., 2011). As bordas sofrem com mais fatores de estresse do que o interior dos fragmentos, como maior exposição ao sol, temperaturas mais elevadas, mais ventos, menor umidade e maior propensão a incêndios.

As bordas dos fragmentos restringem animais e plantas mais sensíveis que podem levar à diminuição da densidade de plantas, eliminação de espécies típicas da área ou substituí-las por espécies exóticas e invasoras que competem por recursos e que podem trazer doenças para a vegetação do fragmento, também se tornam áreas mais susceptíveis à presença de predadores de áreas adjacentes e animais domésticos e a riscos de contaminação por agroquímicos, no caso de fragmentos vizinhos a áreas de agricultura (MMA/SBF, 2003; BRAGA, 2010; NASCIMENTO et al., 2010).

Os efeitos de borda têm interferência mais forte nos primeiros 35 metros adentrando a margem, podendo chegar até 100 metros. Se os fragmentos possuírem uma área de 1 ha o impacto do efeito de borda atinge totalmente o fragmento, num fragmento de 1000 ha o impacto é de mais de $10 \%$ (HERRMANN et al., 2005). Além do tamanho a forma do 
fragmento e a distância entre os fragmentos e a matriz circundante também influenciam no efeito de borda (MMA/SBF, 2003).

A fragmentação é um processo que vem ocorrendo cada vez mais e que tem grande influência sobre a manutenção da biodiversidade. Em busca de soluções para evitar grandes cenários de destruição de habitats e do ritmo acelerado em que os mesmos vêm se ampliando é que a biologia da conservação surge. Primack e Rodrigues (2001) se referem à conservação da biodiversidade como uma ciência multidisciplinar, que tem como base as disciplinas de ecologia, taxonomia, biogeografia, genética, sociologia, antropologia, ética ambiental, legislação, entre outras.

A biologia da conservação é voltada para compreensão e redução de fatores que contribuem para a perda da biodiversidade através de uma investigação nas consequências das atividades humanas para com os ecossistemas e seus integrantes, e desenvolver modos de prevenção de extinção de espécies e reintegração das que se encontram ameaçadas. Ela parte do princípio de que a diversidade biológica é positiva, isto é, proteger a natureza é bom para a humanidade.

A Lei do SNUC (Sistema Nacional de Unidades de Conservação), que será abordado posteriormente, define a conservação da natureza como:

o manejo do uso humano da natureza, compreendendo a preservação, a manutenção, a utilização sustentável, a restauração e a recuperação do ambiente natural, para que possa produzir o maior benefício, em bases sustentáveis, às atuais gerações, mantendo seu potencial de satisfazer as necessidades e aspirações das gerações futuras, e garantindo a sobrevivência dos seres vivos em geral (BRASIL, 2000a, cap. I, art. 2).

A diversidade é fundamental para poder enfrentar as mudanças pelas quais passa o ambiente, pois quanto maior a diversidade, maior a opção de respostas da natureza a estas modificações, é como uma espécie de seguro para manter a estabilidade de ecossistemas (MILANO, 2001) e sua conservação deve ser baseada em ações que promovam a manutenção de seus recursos e riquezas, bem como ataquem as causas e efeitos de sua devastação (BRAGA, 2010).

Para evitar a perda da diversidade biológica e as consequências advindas da mesma, são implementadas políticas e ações de conservação que servem para articular e priorizar medidas e ações que deverão ser tomadas em prol do meio ambiente, suas necessidades e urgências (GANEM, 2007). 
Como citado por Braga (2010), a conservação da biodiversidade pode ser aplicada por meio de diversos tipos de ações a serem executadas, como a proteção de áreas naturais, manejo de ecossistemas, redução do consumo, alteração do padrão de atividade humana, redução da poluição, educação ambiental da população local na área de abrangência, entre outros. A criação de Unidades de Conservação UC's tem sido uma das principais estratégias de preservação e conservação da biodiversidade, não só no Brasil como em todo o mundo (RODRIGUES, 2011).

Numa relação político-econômica, conforme Odum (1988), existe uma falha no mercado relacionada à alocação de recursos naturais, sendo necessária intervenção política para proteção do valor humano e destinação de recursos escassos ou recursos insubstituíveis, dessa forma, através de políticas para implantação de áreas protegidas a terra é retirada do mercado.

O estabelecimento de áreas delimitadas para a conservação de espécies e vários princípios da conservação é embasado na teoria da biogeografia de ilhas e da dinâmica de metapopulações (VALERI \& SENÔ, 2004).

A teoria da biogeografia de ilhas foi desenvolvida por Robert H. MacArthur e Edward O. Wilson em 1967. Ela assume que a quantidade do número de espécies em uma ilha varia de acordo com sua área e a distância de outras ilhas ou do continente. Ilhas que possuem uma área maior apresentam maior quantidade de espécies que ilhas com áreas menores, isto pode ser explicado pela taxa de imigração que varia conforme a distância da ilha ao continente, quanto mais próximo de outro habitat, maiores são as chances de ocorrer a movimentação das espécies, o que garante o fluxo gênico na ilha e maior diversidade biológica (MACARTHUR \& WILSON, 1967).

Outro fator que também sofre interferência é a taxa de extinção, que se relaciona com o tamanho das ilhas, onde ilhas menores possuem menos habitats e recursos disponíveis, ou seja, sua capacidade de suporte é menor. Essas taxas de extinção junto à de imigração, que promove a colonização das ilhas, garantem a manutenção do equilíbrio na quantidade de espécies.

Como citado por Franco (2013); Braga (2010); em 1976 a teoria da biogeografia de ilhas foi contradita quanto aos critérios de seleção de áreas protegidas, no contexto de que áreas maiores seriam melhores do que áreas menores para a conservação das espécies. Dessa contradição surgiu o debate SLOSS ou Single Large or Several Small Reserves, que contesta que algumas áreas pequenas apresentam maiores riquezas de biodiversidade do que certas áreas grandes. Braga (2010) cita que se deve analisar o contexto individual de cada região, pois 
ambas são importantes e necessárias à conservação da biodiversidade, que depende da proteção de diversos habitats dispersos em variadas paisagens.

A teoria de metapopulações se refere ao conjunto de populações formadas por subpopulações com distribuição espacializada e que se conectam por meio de movimentações de seus indivíduos (BRAGA, 2010; VALERI \& SENÔ, 2003). Uma análise na escala da paisagem de uma metapopulação é de grande relevância, pois as populações podem migrar de determinadas áreas para outras ou mesmo se extinguir numa região e aumentar sua população em outra (MMA/SBF, 2003).

$\mathrm{Na}$ teoria de metapopulações se aplica o mesmo contexto de equilíbrio abordado na teoria da biogeografia e em ambas as teorias ficam bem claras a necessidade de haver conectividade entre os fragmentos, sejam eles grandes ou pequenos, para que a migração de espécies e o fluxo de genes possam ocorrer.

Os corredores ecológicos ou corredores da biodiversidade são regiões que fazem a conexão entre fragmentos de vegetação, proporcionando o deslocamento de espécies entre as "ilhas" (PRIMACK e RODRIGUES, 2001). De acordo com o Sistema Nacional de Unidades de Conservação da Natureza - SNUC (Lei 9985/2000), os corredores ecológicos são porções de ecossistemas que unem fragmentos florestais e Unidades de Conservação e cumprem papel de grande importância para a preservação da biodiversidade. Eles promovem a expansão de áreas de vida de diversas espécies animais, que muitas vezes demandam áreas maiores em extensão do que a de unidades individuais, devido ao deslocamento das mesmas. Também contribuem para dispersão de sementes. Dessa forma proporciona o aumento do fluxo gênico da fauna e flora e com isso permitem também a recolonização de áreas degradadas.

Eles são de extrema importância para a riqueza da biodiversidade, pois grande parte das espécies não consegue se deslocar por regiões abertas ou de atividade humana, com os corredores a conectividade entre paisagens são ampliadas, assim a fragilidade e os efeitos da fragmentação de habitats são reduzidos e a diversidade genética e integridade da biota na paisagem são aumentados, enriquecendo os micro-habitats e tornando-os mais fortes e resistentes à pressões que porventura possam interferir na biodiversidade das espécies locais, além de possibilitar maior sobrevivência em casos de algum desastre sobre determinado habitat, pois as espécies teriam por onde se deslocar em busca de novos abrigos, parceiros e recursos (PRIMACK e RODRIGUES, 2001). 


\subsection{UNIDADES DE CONSERVAÇÃO DA BIODIVERSIDADE NO BRASIL E NO DISTRITO FEDERAL}

A ciência da conservação vem ganhando cada dia mais espaço em suas ações contra a perda da biodiversidade, dos recursos naturais e a redução de habitats. Para lidar com diversas situações contrárias ao conservacionismo ela vem produzindo informações com base em dados científicos, questionando princípios sociais, éticos, religiosos e jurídicos, e propondo novas soluções para questões econômicas e políticas que atinjam o meio ambiente, bem como desenvolvendo novas técnicas em prol da conservação (BRITO, 2003).

Para que a conservação ambiental tenha eficiência em sua concretização são necessárias medidas que imponham regras de acesso, exploração e funcionamento no tato com os ecossistemas, bem como medidas educativas tanto no âmbito regional como de uma maneira global, que contemple as mais diversas variações paisagísticas e riquezas naturais.

Estas medidas são necessárias principalmente levando-se em conta as origens do descobrimento do Brasil, que teve desde o início de sua colonização a exploração desenfreada de seus recursos naturais, onde florestas inteiras foram desmatadas pela ação dos portugueses, que viam a ocupação do território brasileiro como uma fonte de matérias-primas para seu sustento e economia e onde pouco importava os meios de ocupação das terras e seu modo de utilização, além do uso dos benefícios de variadas espécies de animais de forma abusiva, inclusive da do próprio homem indígena que até a chegada dos estrangeiros habitava as terras como sendo parte do meio e que passou a mudar sua visão de modo a querer extrair maiores vantagens dos recursos naturais para suprimento de "necessidades" antes não necessárias e de luxo.

Ao longo da história do Brasil a exploração dos recursos naturais foi aumentando junto com a densidade populacional e passou a ter uma relação direta com o desenvolvimento do país. Foi quando se percebeu que as interferências humanas no meio ambiente estavam extinguindo-o e seriam necessárias mudanças para que a sobrevivência da própria espécie humana fosse garantida. Porém, a história da conservação no Brasil tem raízes ainda na época do Brasil Colônia, quando no século XVII começou a surgir uma preocupação com a proteção dos recursos naturais, como o Regimento do Pau-Brasil, promulgado em 1605 por D. Filipe III que determinava que nenhuma pessoa poderia cortar a espécie sem expressa licença (MIRANDA, 2004). 
Em 1796, com a promulgação da Carta Régia, o governo português deu início ao estabelecimento de políticas de controle das matas, com a oficialização de um cargo de juiz para implantação e execução das mesmas, sendo complementadas nos anos posteriores com definição de pertencimento à coroa portuguesa das matas ao redor de rios e cursos d'água, até a criação de um regimento de cortes de madeiras (PEREIRA, 2006), no entanto, as preocupações nesta época eram voltadas para recursos específicos, não havia uma visão de proteção coletiva, nem da importância particular de cada espécie aliada ao equilíbrio nas relações ecológicas.

Foi no século XIX que a conservação da biodiversidade começou a ser praticada. No Brasil, José Bonifácio sugeriu a criação de um setor responsável pela proteção das florestas da Mata Atlântica; no estado do Rio de Janeiro foram criados decretos para a proteção de mananciais, assim como ocorreram desapropriações de terra e plantio de árvores em prol dos mesmos, bem como a proteção de áreas de nascentes (DIEGUES, 1995), sem falar na criação do Jardim Botânico do Rio de Janeiro no ano de 1808 (JBRJ, 2015). Mas foi nos Estados Unidos que a conservação passou a ganhar forma através da criação do Parque Nacional de Yellowstone, no ano de 1872 (RUNTE, 1979). Esta foi a primeira área ambiental com status de Unidade de Conservação.

No Brasil a primeira proposta de criação de Parques Nacionais ocorreu em 1876 pelo engenheiro André Rebouças, que sugeriu a criação de um parque na Ilha do Bananal, no rio Araguaia e outro em Sete Quedas, no rio Paraná. Ambos vieram a se tornar parques nos anos de 1959 e 1961, respectivamente, apesar de o parque de Sete Quedas ter sido extinguido no ano de 1980 para alagamento da área que deu origem à Usina Hidrelétrica de Itaipu (MEDEIROS, 2006; DRUMMOND, FRANCO e OLIVEIRA, 2011).

Em 1891 o decreto de $n^{\circ} 8.843$ criou a Reserva florestal no Acre, que nunca chegou a ser implantada. Também foram criadas duas Estações Biológicas no início do século XX no Brasil, uma criada pelo botânico Alberto Loefgren, localizada em Itatiaia, que posteriormente se tornou Parque Nacional (PARNA) e outra pelo alemão Herman von Ihering, na Serra do Mar (DRUMMOND, FRANCO e OLIVEIRA, 2011).

Os primeiros Parques Nacionais foram criados na década de 1930, os Parques Nacionais do Itatiaia, em 1937 e Iguaçu e Serra dos Órgãos em 1939 (DIEGUES, 1995; DRUMMOND, FRANCO e OLIVEIRA, 2011). Foram estabelecidas também nesta década, entre os anos de 1933 e 34, as primeiras leis de proteção ao meio ambiente, entre eles o Código Florestal, o Código de Caça e Pesca, o Código de Águas e o Código de Minas (OLIVEIRA, 2012). O Código Florestal previa a criação de parques (nacionais, estaduais, municipais) e a classificação 
de florestas de preservação permanente ou com possível exploração de recursos. Também no ano de 1934 foi criada a primeira Estação Florestal Experimental, no estado de São Paulo (DRUMMOND, FRANCO e OLIVEIRA, 2011).

Em 1946 foi criada a primeira UC de uso sustentável, com status de Floresta Nacional, a FLONA do Araripe-Apodi (BRASIL, 1997/2002) e em 1948 foi fundada a União Internacional para a Proteção da Natureza (UIPN) com o objetivo de encontrar soluções para desafios ambientais e no desenvolvimento global, sendo que em 1965 passou a se chamar União Internacional para a Conservação da Natureza (UICN) (BRITO, 2003).

A conservação começava a adensar e avançar, ainda de maneira lenta e discreta até a década de 1960 quando passou a ganhar maior repercussão mundial e força em sua atuação. Somente nesta década foram criadas 10 florestas nacionais, além de, com o advento da criação de Brasília, no ano de 1961 e mudança da capital do Brasil para o centro do país, numa região dominada pelo bioma Cerrado, houve-se a necessidade da criação de áreas protegidas nesta também nesta região, e neste mesmo ano foi criado o Parque Nacional de Brasília e aos arredores do DF, no estado do Goiás, também foram criados o Parque Nacional da Chapada dos Veadeiros e Parque Nacional das Emas (BRASIL, 1997/2002).

No ano de 1965 o Código Florestal brasileiro trouxe mudanças em sua legislação como a criação de duas novas categorias de UC: a Área de Preservação Permanente (APP) e a Reserva Legal (RL) (ABES, 2012) e a divisão entre as Unidades de Conservação restritivas ou de uso indireto (Parques Nacionais, estaduais, municipais e Reservas biológicas) que não permitiam exploração direta de seus recursos naturais, das não-restritivas ou de uso direto (florestas nacionais, estaduais e municipais e parques de caça) que permitiam tal exploração (BRITO, 2003).

Em 1967 foi criado o Instituto Brasileiro para o Desenvolvimento Florestal (IBDF) e em 1973 a Secretaria Especial do Meio Ambiente (SEMA), ambos com foco na conservação ambiental, destacando que a SEMA viabilizou a criação de estações ecológicas e áreas de proteção ambiental em abril de 1981, para representação dos principais ecossistemas brasileiros. (BRASIL, 1981; FONSECA, 2012.).

O final dos anos de 1960 e início de 1970 foram de grande amadurecimento para as políticas de conservação. Na esfera global, em 1968, foi instituído o Clube de Roma, que abriu os olhos da população mundial para a necessidade urgente de mudanças na atuação para com o meio ambiente, observando a proporção de destruição dos recursos e da alta demanda de consumo dos mesmos (PNUMA, 2015) e no mesmo ano foi criada a Reserva Biológica de 
Águas Emendadas, que, em 1988, teve seu status modificado para Estação Ecológica de Águas Emendadas (ALBUQUERQUE, 2008).

Em 1972, na Conferência de Estocolmo, discutiram-se hipóteses de ações para combater o uso abusivo do meio ambiente e propor práticas sustentáveis para a projeção de um futuro em equilíbrio com a natureza e garantindo condições de acesso aos recursos para as próximas gerações. No mesmo ano foi criado o Programa das Nações Unidas para o Meio Ambiente (PNUMA), principal autoridade global sobre o meio ambiente, com o objetivo de manutenção da conservação do meio ambiente global, coordenar ações para informação e bem estar da população que envolvam questões ambientais e promovam o desenvolvimento sustentável (PNUMA, 2015).

Ainda em 1972 foram criadas pela UNESCO (Organização das Nações Unidas para a Educação, a Ciência e a Cultura), as Reservas da Biosfera, integrantes do programa "O Homem e a Biosfera", desenvolvido em parceria do PNUMA com a UICN. As Reservas da Biosfera (RESBIO) têm por finalidade a Pesquisa Cooperativa, a Conservação do Patrimônio Natural e Cultural e a Promoção do Desenvolvimento Sustentável (BRASIL, 2015).

Assembléias Gerais da UICN no Canadá (1970) e no Zaire (1975) também levantaram questões de alerta para que a conservação também atue de modo a impedir a degradação da sociedade, sua cultura e economia (BRITO, 2003) e em 1979 foi formulada a primeira etapa do Plano de Sistema Nacional de Unidades de Conservação no Brasil, que estabeleceu critérios mais definidos para a criação e gestão de UC's.

Em 1981 foram constituídas a Política Nacional de Meio Ambiente o Sistema Nacional de Meio Ambiente (SISNAMA) pela Lei 6.938/81, que também criou o Conselho Nacional do Meio Ambiente (CONAMA) e o processo de licenciamento ambiental no país. O SISNAMA é o órgão responsável pelo estabelecimento de ações em prol da gestão ambiental do Brasil, de modo descentralizado, porém integrativo entre as esferas de governo (SISNAMA/MMA, 2015; BRITO 2003). O licenciamento ambiental foi criado pela lei 6.938/81, porém suas principais diretrizes também estão expressas nas Resoluções CONAMA n 001/86 e n 237/97 (CONAMA, 1986; CONAMA, 1997), sendo que esta de 1986 aborda os critérios de avaliação do impacto ambiental.

Este início dos anos de 1980 até 1984 foi um marco histórico da criação das UC's, sendo 45 o número de unidades criadas neste período, já incluindo nessa contagem duas novas categorias registradas através do Decreto 89.336/84, as Reservas Ecológicas (RE) e as Áreas de 
Relevante Interesse Ecológico (ARIE) (MACIEL, 2011). Dessas UC's 6 foram Parques Nacionais, 9 Reservas Biológicas (ReBio), 2 Reservas Ecológicas e 15 Estações Ecológicas, atingindo um total de aproximadamente 6.800.000,00 hectares protegidos; dentre as de uso sustentável 7 Áreas de Proteção Ambiental (APAs), 4 ARIEs e 1 Floresta Nacional. (BRASIL, 1997/2002). Desse total de 7 APAs, 5 foram criadas no DF: APA da Cafuringa, APA do Lago Paranoá, APA da Bacia do Ribeirão do Gama e Cabeça de Veado, APA da Bacia do Rio Descoberto e APA da Bacia do Rio São Bartolomeu.

O crescimento da abordagem de cunho ambiental ganhava maiores proporções e relevância, os recursos naturais e a preservação do meio ambiente estavam cada vez mais articulados a órgãos e políticas de foco conservacionista que construíam melhores formas de gerenciamento e regras para atingir a eficácia no controle da proteção e de acesso ao meio ambiente, além de buscarem maneiras para que o país continuasse se desenvolvendo e ao mesmo tempo toda a humanidade pudesse obter de modo igualitário uma vida com qualidade e disponibilidade de um meio ambiente saudável, rico e abundante.

Entre os anos de 1985 e 1989 foram criadas mais 22 Unidades de Conservação de proteção integral, sendo 8 Parques Nacionais, 7 Reservas biológicas e 7 estações ecológicas, com abrangência de mais de 2.500.000,00 hectares, além de florestas nacionais, APAs e ARIEs que somadas apresentam uma área de mais de 9.000.000 de hectares (BRASIL, 1997/2002). Entre essas UC's podemos destacar o Jardim Botânico de Brasília, criado em 1985 pelo Decreto no 8.497 e que passou a se chamar Estação Ecológica do Jardim Botânico, sob o Decreto $\mathrm{n}^{\mathrm{o}} 14.422$ no ano de 1992 (JBB, 2015).

Também em 1985, através do Decreto $\mathrm{n}^{\circ}$ 91.145, foi criado o Ministério do Desenvolvimento Urbano e Meio Ambiente, que passou a chamar-se Ministério do Meio Ambiente em 1992 (BRASIL, 1985; OLIVEIRA, 2012). Em 1988 foi promulgada a Constituição da República Federativa do Brasil que atribuiu como competência da União, Estados, Distrito Federal e Municípios a proteção ao meio ambiente para as presentes e futuras gerações e que assegurou que todos têm direito a um meio ambiente ecologicamente equilibrado, de uso comum e que proporcione qualidade de vida, em seus artigos 23 e 225 (BRASIL, 1988).

No ano de 1989 foi fundado o Instituto Brasileiro de Meio Ambiente e dos Recursos Naturais Renováveis (IBAMA), englobando o IBDF e a SEMA, sendo responsável pela execução da política nacional do meio ambiente, bem como da preservação, conservação e uso racional, controle e fomento dos recursos naturais renováveis Lei 7.735/89 (BRASIL, 1989). 
Em 1990 surgiram as primeiras Reservas Particulares do Patrimônio Natural (RPPN), com base no Decreto Federal n 98.914, caracterizadas como categorias de manejo. Só no ano de 1990 foram criadas 10 unidades, até 1993 mais 41, de 1994 a 1996 mais 53 e de 1997 a 2000 mais 204 RPPNs. Nos anos de 1990 a 1994 também foram criadas mais cinco 5 UC's de proteção integral, 30 UC's de uso sustentável, com destaque para as florestas nacionais e Reservas extrativistas. De 1995 a 1999 mais 9, sendo dessas 8 Parques Nacionais, 1 Reserva Biológica, entre várias outras de uso sustentável, como a Floresta Nacional de Brasília, no Distrito Federal e APA de Cafuringa (BRASIL, 1997/2002; CNUC/MMA, 2015).

No ano de 1994 foi criada a Reserva da Biosfera do Cerrado, sob a Lei no 742/94, com a finalidade de implantação de um projeto piloto de desenvolvimento e conservação, com vista à geração de resultados aplicáveis em todo o Cerrado (BRASIL, 1994). Em 1997 podem ser citados outros tipos de áreas de proteção ambiental, as Áreas de Proteção de Mananciais do Distrito Federal (APM), que foram criadas através da Lei Complementar $n^{\circ} 17$, em janeiro de 1997 e regulamentadas pelo Decreto 18.585/97. São áreas que também abordam a vertente de conservação, recuperação e manejo, mas exclusivamente de bacias hidrográficas que abastecem os pontos de captação de água da Caesb (CAESB, 2015). No ano de 1998 também foi criada a Lei de crimes ambientais $n^{\circ} 9.605$, que dispõe sobre as sanções penais e administrativas derivadas de condutas e atividades lesivas ao meio ambiente (BRASIL, 1998).

Como marco do ano 2000, no mês de julho foi instituído no Brasil pela Lei 9.985 o SNUC - Sistema Nacional de Unidades de Conservação que veio consolidar o arcabouço normativo de todas as categorias de manejo usadas no Brasil, sendo responsável pelos critérios e normas para criação, implantação e gestão de UC's federais, estaduais e municipais.

A Lei traz em seu artigo $2^{\circ}$ a definição de Unidade de Conservação como:

\footnotetext{
Espaço territorial e seus recursos ambientais, incluindo as águas jurisdicionais, com características naturais relevantes, legalmente instituído pelo Poder Público, com objetivos de conservação e limites definidos, sob regime especial de administração, ao qual se aplicam garantias adequadas de proteção (BRASIL,2000a, cap I, art 2).
}

Com o SNUC as Unidades de Conservação passaram a ser agrupadas em dois tipos de categorias, de acordo com características específicas de suas áreas protegidas: as Unidades de Proteção Integral e as Unidades de Uso sustentável. As Unidades de Proteção Integral 
apresentam o objetivo de preservação da natureza, permitindo apenas o uso indireto dos seus recursos naturais, exceto os casos previstos em Lei. Já as Unidades de Uso Sustentável o objetivo é a conservação da natureza, permite o uso sustentável de parte de seus recursos naturais (BRASIL, 2000a).

As Unidades de Proteção Integral são as seguintes: Estação Ecológica; Reserva Biológica, Parque Nacional, Monumento Natural e Refúgio de Vida Silvestre; as Unidades Uso Sustentável: Área de Proteção Ambiental, Área de Relevante Interesse Ecológico, Floresta Nacional, Reserva Extrativista, Reserva de Fauna, Reserva de Desenvolvimento Sustentável e Reserva Particular do Patrimônio Natural (BRASIL, 2000a).

A Unidade de Conservação objeto de estudo deste trabalho se encontra sob o status de uma Reserva Biológica, presente na categoria de Unidades de Proteção Integral, e, de acordo com a Lei do SNUC, as Reservas Biológicas tem como objetivo a preservação integral da biota e demais atributos naturais pertencentes ao seu território, onde não há interferência humana direta ou modificações em seu ambiente, exceto casos de manejo e recuperação de áreas, sempre com vistas a preservar o ambiente natural, a diversidade biológica e os processos ecológicos naturais.

Entre os anos de 2000 a março de 2002, mais 10 Unidades de Conservação foram criadas, sendo quatro 4 Parques Nacionais, 6 estações ecológicas e outras UC's de uso sustentável, entre elas a APA do Planalto Central e mais de 14 RPPNs (BRASIL, 1997/2002). Em dezembro de 2002, através de decreto foi criada a Reserva Biológica da Contagem, área de estudo desta dissertação, mas que será melhor abordada adiante (CNUC/MMA, 2015).

Em 2007 foi criado o Instituto Chico Mendes de Conservação da Biodiversidade (ICMBIO) e assim a gestão das Unidades de Conservação se tornou sua atribuição, deixando de ser competência do IBAMA (MACIEL, 2011; FONSECA, 2012; OLIVEIRA, 2012) e também foi criado o Instituto do Meio Ambiente e dos Recursos Hídricos do Distrito Federal - Brasília Ambiental (IBRAM), responsável pela execução de políticas públicas ambientais e de recursos hídricos no Distrito Federal, e que, além disso, também opera em UC's concedendo autorização para entrada nas unidades e administração dos parques ecológicos do DF (IBRAM, 2014; IBRAM, 2015).

Em 2010, através da Lei Complementar ${ }^{\circ}$ 827, o Distrito Federal instituiu o seu próprio sistema de UC's, o SDUC - Sistema Distrital de Unidades de Conservação, sendo constituído da seguinte maneira: para Unidades de Proteção Integral, temos as categorias: Estação Ecológica; Reserva Biológica, Parque Distrital, Monumento Natural e Refúgio de Vida 
Silvestre. Dentre as Unidades Uso Sustentável estão presentes as categorias: Área de Proteção Ambiental, Área de Relevante Interesse Ecológico, Floresta Distrital, Parque Ecológico, Reserva de Fauna e Reserva Particular do Patrimônio Natural (BRASIL, 2010).

Esses principais eventos da conservação no Brasil e Distrito Federal podem ser visualizados na Tabela 1, sendo que os destacados no DF abrangem os mais importantes para a área de estudo.

Tabela 1. Legislações e políticas de grande relevância para a conservação ambiental do Brasil e DF.

\begin{tabular}{|c|c|c|}
\hline Lei ou Política & Data & Evento \\
\hline Regimento do Pau-Brasil & 1605 & ninguém pode cortar a espécie sem expressa licença \\
\hline Carta Régia & 1796 & início do estabelecimento de políticas de controle das matas \\
\hline Decreto Real de D. João VI & $13 / 06 / 1808$ & criação do Jardim Botânico do Rio de Janeiro \\
\hline Hermann von Ihering & 1909 & criação da primeira Estação Biológica do Brasil: Alto da Serra (SP) \\
\hline Decreto $n^{\circ} 23.793$ & $23 / 01 / 1934$ & criação do Código Florestal \\
\hline Decreto $n^{\circ} 24.104$ & $10 / 04 / 1934$ & $\begin{array}{l}\text { criação da primeira Estação Florestal Experimental do Brasil: Dr. Epitácio } \\
\text { Santiago (SP) }\end{array}$ \\
\hline 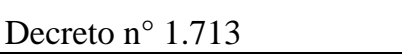 & $14 / 06 / 1937$ & criação do primeiro Parque Nacional do Brasil: Itatiaia \\
\hline Decreto $\mathrm{n}^{\circ} 9.226$ & $02 / 05 / 1946$ & $\begin{array}{l}\text { criação da primeira UC de uso sustentável do Brasil: Floresta Nacional de } \\
\text { Araripe-Apodi (CE) }\end{array}$ \\
\hline Decreto $^{\circ} 241$ & 29/11/1961 & criação do Parque Nacional de Brasília \\
\hline Lei $n^{\circ} 4.771$ & $15 / 09 / 1965$ & $\begin{array}{l}\text { criado Novo Código Florestal, com inclusão de duas novas categorias de UCs: } \\
\text { Áreas de Preservação Permanente e Reserva Legal }\end{array}$ \\
\hline Decreto-lei n ${ }^{\circ} 289$ & $28 / 02 / 1967$ & criado o Instituto Brasileiro de Desenvolvimento Florestal - IBDF \\
\hline Decreto $\mathrm{n}^{\circ} 771$ & $12 / 08 / 1968$ & $\begin{array}{l}\text { criada a Reserva Biológica de Águas Emendadas, que em } 1988 \text { teve seu status } \\
\text { modificado para Estação Ecológica de Águas Emendadas }\end{array}$ \\
\hline Decreto $\mathrm{n}^{\circ} 73.030$ & $30 / 10 / 1973$ & criada a Secretaria Especial do Meio Ambiente \\
\hline IBDF & 1979 & $\begin{array}{l}\text { formulada a } 1^{\mathrm{a}} \text { etapa do Plano de Sistema Nacional de Unidades de } \\
\text { Conservação no Brasil }\end{array}$ \\
\hline Lei $n^{\circ} 6.902$ & 27/04/1981 & $\begin{array}{l}\text { criação das categorias de conservação: Estação Ecológica e Área de Proteção } \\
\text { Ambiental }\end{array}$ \\
\hline Lei $n^{\circ} 6.938$ & $31 / 08 / 1981$ & $\begin{array}{l}\text { Constituída a Política Nacional de Meio Ambiente que criou o Sistema } \\
\text { Nacional de Meio Ambiente - SISNAMA e Conselho Nacional do Meio } \\
\text { Ambiente-CONAMA }\end{array}$ \\
\hline Decreto $n^{\circ} 89.336$ & $31 / 01 / 1984$ & $\begin{array}{l}\text { registro de duas novas categorias de UC: Reserva Ecológica e Área de } \\
\text { Relevante Interesse Ecológico }\end{array}$ \\
\hline Decreto $\mathrm{n}^{\circ} 8.797$ & 08/03/1985 & $\begin{array}{l}\text { criação do Jardim Botânico de Brasília, que em } 1992 \text { teve seu status } \\
\text { modificado para: Estação Ecológica do Jardim Botânico }\end{array}$ \\
\hline Decreto $n^{\circ} 91.145$ & $15 / 03 / 1985$ & $\begin{array}{l}\text { criação do Ministério do Desenvolvimento Urbano e Meio Ambiente, que em } \\
1992 \text { teve seu nome alterado para: Ministério do Meio Ambiente }\end{array}$ \\
\hline Decreto $\mathrm{n}^{\circ} 11.123$ & $10 / 06 / 1988$ & criação da APA de Cafuringa \\
\hline Lei $n^{\circ} 7.735$ & 22/02/1989 & $\begin{array}{l}\text { fundação do Instituto Brasileiro do Meio Ambiente - IBAMA, englobando o } \\
\text { IBDF e a SEMA }\end{array}$ \\
\hline Decreto $n^{\circ} 98.914$ & $31 / 01 / 1990$ & criação da categoria de UC: Reserva Particular do Patrimônio Natural - RPPN \\
\hline UNESCO & 1991 & criação da primeira Reserva da Biosfera do Brasil: da Mata Atlântica \\
\hline Lei $\mathrm{n}^{\circ} 742$ & 28/07/1994 & criação da Reserva da Biosfera do Cerrado \\
\hline Decreto $\mathrm{n}^{\circ} 18.585$ & 09/09/1997 & $\begin{array}{l}\text { criação da categoria de conservação Área de Proteção de Manancial - APM, } \\
\text { regulamentando as APMs criadas pelo PDOT: Art. } 30 \text { de Lei Complementar } \\
\mathrm{n}^{\circ} 17 \text {, de } 28 / 01 / 1997\end{array}$ \\
\hline
\end{tabular}




\begin{tabular}{|c|c|c|}
\hline Lei $\mathrm{n}^{\circ} 9.605$ & $12 / 02 / 1998$ & criada a lei que dispõe sobre crimes ambientais \\
\hline Lei $\mathrm{n}^{\circ} 9.985$ & $18 / 07 / 2000$ & criação do Sistema Nacional de Unidades de Conservação - SNUC \\
\hline Decreto $\mathrm{s} / \mathrm{n}$ & $10 / 01 / 2002$ & criação da APA do Planalto Central \\
\hline Decreto s/n & $13 / 12 / 2002$ & criação da Reserva Biológica da Contagem \\
\hline Lei $n^{\circ} 3.984$ & $28 / 05 / 2007$ & $\begin{array}{l}\text { criação do Instituto do Meio Ambiente e dos Recursos Hídricos do Distrito } \\
\text { Federal - Brasília Ambiental (IBRAM) }\end{array}$ \\
\hline Lei $n^{\circ} 11.516$ & 28/08/2007 & $\begin{array}{l}\text { criação do Instituto Chico Mendes de Conservação da Biodiversidade - } \\
\text { ICMBio }\end{array}$ \\
\hline Lei Complementar $n^{\circ} 287$ & $22 / 07 / 2010$ & instituído o Sistema Distrital de Unidades de Conservação - SDUC \\
\hline
\end{tabular}

Atualmente existe um total de 1.940 Unidades de Conservação no Brasil, considerando as esferas federais, estaduais e municipais, sendo 586 Unidades de Proteção Integral que abrangem uma área de $528.007 \mathrm{Km}^{2}$ e 1.354 Unidades de Uso Sustentável, que com área de 1.023.189 km², conforme dados do Cadastro Nacional de Unidades de Conservação, atualizados em 17/02/2015 (CNUC/MMA, 2015a).

O Distrito Federal se encontra entre as Unidades da Federação com maior número de Unidades de Conservação, tanto com função de conservação da biodiversidade como de turismo, enquadradas em uma das categorias do SNUC ou SDUC, apresentando mais $90 \%$ de seu território sob regulamentação de alguma UC, principalmente de APAs (IBRAM, 2014). Ao todo o DF conta com 33 UC's do SNUC, cadastradas no CNUC, mais 73 parques ecológicos e urbanos, 26 Áreas de Proteção de Mananciais, entre outras.

\subsection{SUSTENTABILIDADE DE UNIDADES DE CONSERVAÇÃO}

A ideia de sustentabilidade teve início a partir da década de 1970, com a realização da Conferência Internacional do Clube de Roma, realizada em 1972, na qual foram questionados o aumento da produção industrial, o crescimento demográfico e a limitação dos recursos naturais disponíveis, o que gerou a elaboração de um trabalho chamado: The limits to growth (Limites do crescimento), que tinha como proposta para a estabilidade econômica e ecológica, o congelamento do crescimento populacional e do capital industrial (JACOBI, 2003).

Este foi o pontapé inicial para discutirem-se mundialmente os problemas ambientais. Entretanto, a conferência gerou várias críticas, principalmente para os países de terceiro mundo que estavam começando a desenvolver um progresso na economia com o avanço da industrialização, pois propunha o "crescimento zero" onde os países deveriam parar o seu 
desenvolvimento para resolver problemas ecológicos ocasionados pelos países mais desenvolvidos (FMCS, 2008). Este freio no desenvolvimento não ocorreu, porém desencadeou novos movimentos de apoio à questões ambientais.

Diante do cenário de discussões a respeito do tema, em junho do mesmo ano foi realizada pela ONU (Organização das Nações Unidas) a Conferência de Estocolmo, na qual a questão ambiental foi o foco das preocupações internacionais e ganhou espaço na esfera pública. Em 1973, surgiu o termo "ecodesenvolvimento" por Maurice Strong, que foi posteriormente melhor definido por Ignacy Sachs, que formulou como princípios a sustentabilidade nos âmbitos social, econômica, ecológica, espacial e cultural (MENDES, 2009).

$\mathrm{Na}$ década de 1980, a ONU cria a Comissão Mundial sobre Meio Ambiente e Desenvolvimento (CMMAD), sob comando de Harlem Brudtland ex-primeira ministra da Noruega, com o objetivo de produzir um relatório com os resultados de reuniões realizadas em todo o mundo, buscando o desenvolvimento humano e a preservação dos recursos. Somente em 1987 que este relatório foi apresentado, conhecido como Our Common Future (Nosso Futuro Comum) ou Relatório Brudtland, que trouxe pela primeira vez o conceito de desenvolvimento sustentável definido como "atende as necessidades do presente, sem comprometer a capacidade das gerações futuras de atenderem suas próprias necessidades" (FMCS, 2008 p. 73), e assim o ecodesenvolvimento deu lugar ao desenvolvimento sustentável, pois o crescimento econômico tornou-se prioridade.

No ano de 1992, a ONU organizou uma nova conferência internacional, a Rio 92, realizada no Rio de Janeiro, dela surgiu a Agenda 21, documento com várias instruções para tornar o desenvolvimento sustentável um instrumento de prática social efetiva no século 21 (FMCS, 2008).

Dez anos após houve a Cúpula Mundial sobre Desenvolvimento Sustentável ou RIO+10, ocorrida em Johannesburgo a cúpula fez uma avaliação dos resultados obtidos pela Agenda 21 e deu destaque a problemas relacionados à globalização (FMCS, 2008). Já em 2012 a Rio + 20, ocorrida na cidade do Rio de Janeiro, trouxe como objetivo a renovação do compromisso político com o desenvolvimento sustentável e a abordagem da economia verde e a estrutura institucional para o desenvolvimento sustentável (RIO20, 2015).

Atualmente, a sustentabilidade é um tópico presente não só na esfera ambiental, mas se relaciona com questões políticas gerenciais tanto no público como no privado, no nacional como no internacional, bem como em empresas e indústrias, na abordagem sócio-cultural e educacional das populações, além de aparecer no aspecto econômico-social através do 
desenvolvimento sustentável. Porém, por se tratar de um assunto ainda recente e em fase de expansão de metodologias e conhecimentos para aplicação do mesmo, é muitas vezes encarado somente na teoria ou como uma utopia, por conta das dificuldades de frear a exploração que está presente em tudo o que é produzido atualmente e de onde se extrai todas as matériasprimas (AMORIM, 2009).

A sustentabilidade também é um aspecto a ser trabalhado mesmo em áreas já destinadas à preservação dos recursos naturais, como as Unidades de Conservação, pois somente o fato de se estabelecer áreas de conservação não garante o cumprimento dos objetivos propostos e consequentemente os resultados esperados para a mesma (SANTOS et al., 2013), ainda mais tendo em vista que a degradação dos ecossistemas ainda é um processo notório.

Mas como é possível tornar sustentável e aplicar ações em prol deste equilíbrio entre a natureza e o modo de vida e ocupação da sociedade em áreas que já receberam um isolamento do meio urbano e que já foram determinadas para a conservação do meio ambiente? Quais as diferenças que podem existir entre Unidades de Conservação que apresentam ações de sustentabilidade para outras que não as apresentam?

Embora as Unidades de Conservação, mesmo as de proteção integral que apresentam maior isolamento do contato com o homem, estejam restritas a determinados impactos diretos sobre sua biodiversidade, estas também necessitam de práticas sustentáveis tanto dentro da UC como em seu entorno. Caso contrário a mesma terá seus recursos e material genético restritos à sua região de abrangência, caracterizando o local como uma ilha, conforme a teoria da biogeografia de ilhas, contando ainda com o agravante de grande pressão antrópica ao seu redor.

Algumas medidas, de acordo com a Convenção Brasileira de Diversidade Biológica, são necessárias para a conservação e utilização sustentável:

Desenvolver estratégias, planos ou programas para a conservação e a utilização sustentável da diversidade biológica ou adaptar para esse fim estratégias, planos ou programas existentes que devem refletir, entre outros aspectos, as medidas estabelecidas nesta Convenção concernentes à Parte interessada; e Integrar, na medida do possível e conforme o caso, a conservação e a utilização sustentável da diversidade biológica em planos, programas e políticas setoriais ou intersetoriais pertinentes. (BRASIL, 2000, Artigo 6, p. 11)

A sustentabilidade, diferentemente da ideia de que seja um tema contido somente na esfera ambiental, é composta de várias vertentes que quando vinculadas constituem o arcabouço no qual ela ganha representatividade. Conforme visto na definição de Ignacy Sachs 
(MENDES, 2009), a sustentabilidade é encontrada em cada dimensão de desenvolvimento, na dimensão social, na econômica, na ecológica e na política, e para que haja sustentabilidade da biodiversidade em UC's de proteção integral é necessário que haja sustentabilidade nessas dimensões (HOROWITZ, 2003).

Estas dimensões de atuação da sustentabilidade demonstram que não basta ter uma região delimitada para que a natureza seja preservada, caso demais fatores também não colaborem com a conservação da biota do local. A sustentabilidade de UC's sofre grande influência de ações externas, principalmente vindas do entorno das áreas protegidas, o que exige e execução de ações sustentáveis muito além das realizadas diretamente com o meio ambiente para que seja estabelecido e mantido um ambiente rico e autossuficiente, do contrário com o passar dos anos e aumento de pressões antrópicas e demanda por recursos, a área protegida estará com suas comunidades em risco.

\subsection{ESTRATÉGIAS PARA SUSTENTABILIDADE E A ANÁLISE ESPACIAL}

Por mais que os ecossistemas sejam resilientes e consigam se recuperar bem da maioria dos distúrbios e o meio ambiente passe por processos contínuos de mudança, eles precisam de tempo para que isso possa ocorrer, não conseguindo se adaptar a persistentes e crescentes mudanças resultantes das atividades humanas (NB Biodiversity Working Group, 2009). Como é impossível conter as atividades e as demandas do homem, a elaboração de estratégias como tentativas de amenizar a exploração e o impacto ambiental são extremamente necessárias.

Ansoff define a estratégia como "regras de decisão em condições de desconhecimento parcial" (ANSOFF, 1977, p.101).

Zaccarelli define estratégia como:

é um guia para decisões sobre interações com oponentes, de reações imprevisíveis, que compreende duas parte:

- ações e reações envolvendo aspectos do negócio;

- preparação para obter vantagens nas interações. (Zacarelli, 2012, p.73)

Entre as premissas da escola ambiental está a de que o ambiente, conjunto de forças gerais, é o agente central no processo de geração de estratégia (MINTZBERG, AHLSTRAND e LAMPEL, 2000). 
Em razão da oferta limitada de recursos naturais e para otimizar a disponibilização dos mesmos, ocorrem mudanças no cenário econômico que buscam o equilíbrio dos negócios, com isso a sustentabilidade deixa de ser uma opção e passar a ser uma condição de sobrevivência (Gruba, 2013).

Mintzberg et al. (2006), afirma que para que uma posição estratégica seja sustentável é necessário haver intercâmbio com outras posições. No caso da conservação, para que estratégias abordadas nessa esfera tenham força em sua atuação, elas precisam trabalhar em conjunto com outras políticas ambientais, tratando de questões que a princípio pareçam sem solução ou inviáveis politicamente falando.

De acordo com Alfred (2014) uma abordagem estratégica, holística e um planejamento de longo prazo são bases para o desenvolvimento sustentável. Para (GTZ, 2006) planejamentos estratégicos são mais propensos a serem bem sucedidos quando possuem uma visão de longo prazo, e quando são planejados em prol da sustentabilidade devem ser construídos sobre os programas que o local já possui, possibilitando assim convergência, complementariedade e coerência nas ações estratégicas.

Outro aspecto muito importante para que as estratégias de sustentabilidade sejam viáveis, são as atividades de manejo de ecossistemas e a integração de comunidades tradicionais e locais nas redondezas das UC's. Elas ajudam a esclarecer à população sobre a relevância dos processos ecológicos, dos distúrbios que eles sofrem e da forma de mantê-los e reestruturá-los.

A definição de estratégias para a conservação da biodiversidade e a identificação de áreas prioritárias para a criação de novos espaços protegidos, devem ultrapassar os limites das Unidades de Conservação e considerar o potencial de conservação nos fragmentos vizinhos. Esse enfoque holístico a nível de paisagem é fundamental para o aumento da eficácia dessas áreas para a conservação da biodiversidade (VIANA \& PINHEIRO, 1998).

Para Christofoletti (1999), uma abordagem holística sistêmica é necessária para compreender como entidades ambientais físicas se estruturam e funcionam como diferentes unidades complexas. São sistemas menores que condicionam e influenciam sistemas maiores nos quais estão inseridos ou envolvidos.

Os fatores ambientais componentes das paisagens também necessitam de análises correlacionadas, pois as características de fatores isolados ou em um determinado ecossistema podem apresentar grandes diferenças de respostas, que variam conforme suas relações ecológicas. O uso da ecologia de paisagens pode levar à elaboração de um retrato mais integrado para as regiões, com isso a fragmentação tende a ser reduzida (RICKLEFS, 2010). 
Como citado por Angelini (1999), ecossistemas evoluem e desenvolvem-se e através de análises de redes tróficas é possível quantificar o estágio de evolução de um ecossistema, por meio de suas propriedades emergentes (relações de fluxos de energia no sistema), que se analisadas separadamente não é possível observar esse desenvolvimento, elas emergem quando os componentes estão interligados.

Uma maneira de melhor compreender as relações ecológicas; os resultados obtidos dessas relações; ou se verificar o quão certos fatores, sejam eles bióticos, abióticos, intraespecíficos ou interespecíficos; exercem ou sofrem influência diante de determinadas circunstâncias; e até mesmo quantificar a influência dessas relações; pode ser obtida através da utilização de modelos.

Modelos espaciais são fundamentais para representar a organização do espaço, principalmente por conta da complexidade das relações dos sistemas físico/naturais com a ocupação humana, em que a atuação do homem na escala de tempo presente, é capaz de modificar ou interferir a escala de tempo da natureza (FILHO, CUARESMA e RODRIGUES, 2008).

Nas análises de Angelini (1999), a construção de um modelo busca delimitar um sistema, identificar seus componentes e relações com os fenômenos correlacionados e escolher um objeto para quantificar. Os modelos ajudam na simplificação de sistemas, visto que os mais complexos são formados por outros menores, até se chegar à composição estrutural da unidade e mesmo as unidades são formadas por subunidades e substâncias menores que às compõem, ocorrendo sempre relações em cadeia que podem ser destrinçadas para compreensão de funcionamento dos sistemas.

A modelagem de dados é uma ferramenta que conquistou espaço no meio científico devido à possibilidade de selecionar diferentes aspectos e fazer diversas correlações entre eles em meio à ampla dimensão compreendida, enquanto apresenta precisão nas informações extraídas, resultantes dos modelos aplicados. Além de ser possível manipular os dados, permitindo-se assim compreender fenômenos que só hipoteticamente não conseguiriam fornecer informações específicas e com alto nível de detalhes.

Os dados geográficos, que também podem ser denominados dados espaciais, são assim chamados por apresentarem uma localização no espaço geográfico (CÂMARA et al., 1996). Por meio de técnicas de Geoprocessamento é possível modelar dados geográficos de diversas áreas de conhecimento. 
O Geoprocessamento é uma disciplina que por meio de tecnologias e técnicas matemáticas promove o tratamento de informações geográficas e é utilizado como uma ferramenta estratégica para soluções específicas. O processamento de dados espaciais vem influenciando bastante as áreas de Cartografia, Análise de Recursos Naturais, Transportes, Comunicações, Energia e Planejamento Urbano e Regional; sendo também utilizado para o desenvolvimento de projetos e pesquisas voltados para administração, planejamento e tomada de decisão (CÂMARA e DAVIS, 2001).

Para que os dados geográficos possam ser trabalhados, desde a sua entrada, manipulação, análise, obtenção de informações geográficas e armazenamento, são utilizadas ferramentas computacionais, também conhecidas como Sistemas de Informações Geográficas (SIG) (CÂMARA e DAVIS, 2001).

Os SIG's possibilitam a execução de uma enorme variedade de processos sobre os dados, sendo a modelagem fundamental para a obtenção de novas informações para análise espacial. Os procedimentos de análise espacial permitem relacionar dados físicos, dados socioeconômicos, ou outros tipos de dados que sejam essenciais para estudos de planejamento ambiental a partir de unidades de paisagem mapeadas de imagens de satélites (RUHOFF, 2004), sendo aplicados para a gestão do espaço urbano (CARVALHO, 2002).

Conforme Christofoletti (1999), a modelagem funciona como pontes entre os níveis da observação e as proposições teóricas e pode ser utilizada para solucionar problemas propostos e garantir a manutenção do ambiente.

A modelagem de dados espaciais está relacionada com modelos expressos em mapas, podendo ser uma coleção de mapas, ou camadas de mapas de uma mesma área e até operações entre seus elementos, que através de técnicas avançadas de análise espacial relacionadas com a linguagem de álgebra de mapas no processamento de dados, permitem caracterizações de uma vizinhança cartográfica, bem como medidas de distância, conectividade, rotas ótimas e análises estatísticas (BERRY, 2009).

A utilização do SIG associado a métodos de modelagem cartográfica permite a produção de mapas que facilitam a visualização de informações, possibilitando a correlação de diferentes temas capazes de gerar novos resultados e desenvolver diferentes parâmetros de análise. (CARVALHO, 2002). Uma análise quando realizada através de um SIG, possibilita uma melhor compreensão do problema e, consequentemente, encontrar soluções ou medidas mitigadoras para a resolução do mesmo de modo mais rápido, agilizando tomadas de decisão 
tanto em nível governamental como no gerenciamento de uma empresa (CRUZ e CAMPOS, 2005).

Sistemas de Informações Geográficas podem ser utilizados em diversas áreas, Ramirez (1994) divide as aplicações em cinco grupos principais:

- Ocupação Humana: redes de infra-estrutura; planejamento e supervisão de limpeza urbana; cadastramento territorial urbano; mapeamento eleitoral; rede hospitalar; rede de ensino; controle epidemiológico; roteamento de veículos; planejamento urbano; sistema de informações turísticas; controle de tráfego aéreo; sistemas de cartografia náutica; serviços de atendimentos emergenciais.

- Uso da Terra: planejamento agropecuário; estocagem e escoamento da produção agrícola; classificação de solos; gerenciamento de bacias hidrográficas; planejamento de barragens; cadastramento de propriedades rurais; levantamento topográfico e planimétrico; mapeamento do uso da terra.

- Uso de Recursos Naturais: controle do extrativismo vegetal e mineral; classificação de poços petrolíferos; planejamento de gasodutos e oleodutos; distribuição de energia elétrica; identificação de mananciais; gerenciamento costeiro e marítimo.

- Meio Ambiente: controle de queimadas; estudos de modificações climáticas; acompanhamento de emissão e ação de poluentes; gerenciamento florestal de desmatamento e reflorestamento.

- Atividades Econômicas: planejamento de marketing; pesquisas socioeconômicas; distribuição de produtos e serviços; transporte de matéria-prima.

Estas são algumas das aplicações possíveis de serem trabalhadas com essa ferramenta de grande inteligência geográfica. As análises ambientais que utilizam SIGs estão se ampliando e gerando vários resultados importantes para avaliar efeitos decorrentes do uso e ocupação do solo e, assim, propor mudanças para melhorias ambientais, como os trabalhos de Tong e Chen (2002), Fortes et al. (2003), Santos et al. (2011), Francisco et al. (2007) e Olivetti et al. (2015). 


\section{3 ÁREA DE ESTUDO}

\subsection{O CERRADO E AS OCUPAÇÕES URBANAS VIZINHAS À ÁREA DE ESTUDO}

O bioma Cerrado é o segundo maior do Brasil, com uma extensão de cerca de 2 milhões de $\mathrm{km}^{2}$ e ocupa $24 \%$ do território nacional, sendo atualmente considerado como um dos 34 hotspots mundiais para a conservação, devido a sua alta biodiversidade e ameaça ambiental. (MYERS et al., 2005).

No cerrado podem ser identificados 11 tipos principais de fitofisionomias, agrupadas em três tipos de formação vegetal: florestais, savânicas e campestres. As florestais são áreas com predominância de espécies arbóreas onde há formação de dossel contínuo ou descontínuo (mata ciliar, mata de galeria, mata seca e cerradão). As savânicas são áreas com árvores e arbustos espalhados sobre um estrato graminoso, sem formação de dossel contínuo, (cerrado sentido restrito, parque de cerrado, palmeiral e vereda). As campestres são áreas com predomínio de espécies herbáceas e algumas arbustivas, sem ocorrência de árvores na paisagem (campo sujo, campo rupestre e campo limpo) (RIBEIRO \& WALTER, 2008)

Cada uma dessas fitofisionomias compõem habitats que abrigam as mais variadas espécies de plantas e animais presentes no Cerrado. São mais de 12.000 plantas vasculares, 800 espécies de aves, além de grande variedade de peixes e outras formas de vida. Só no Distrito Federal foram identificadas 138 espécies de mamíferos, 460 espécies de aves, 47 espécies de anfíbios e 111 de répteis e no grupo dos peixes foram identificadas 77 espécies (IBRAM, mapa ambiental, 2014).

O Distrito Federal tem $100 \%$ do seu território na área nuclear da região do Cerrado, porém hoje resta cerca de $1 / 3$ da cobertura vegetal natural do Cerrado. De acordo com o PROBIO-MMA (2009), em 2007, o Cerrado já havia perdido cerca de $40 \%$ da sua cobertura vegetal natural.

O Distrito Federal vem passando por um grande processo de expansão urbana, não sendo diferente para a Região Administrativa de Sobradinho, onde se localiza a ReBio da Contagem. Segundo os dados da Pesquisa Distrital por Amostra de Domicílios - PDAD 2010/2011, a população urbana estimada da região de Sobradinho para o ano de 2011 era de 85.491 habitantes, enquanto que em 2004 era de 61.290. A Taxa Média Geométrica de Crescimento 
Anual - TMGC de Sobradinho, entre as duas PDADs 2004/2011, é de 4,9\%, acima do Distrito Federal, conforme os Censos de 2000 e 2010, que é de 2,3\%. (CODEPLAN, 2011).

Tamanho crescimento populacional, também atinge os condomínios do Grande Colorado e Núcleo Rural Lago Oeste, instalados em torno da Reserva Biológica, que de forma direta e indireta exercem grande pressão antrópica na Unidade de Conservação e ocasionam diversos impactos ambientais como desmatamentos para construção de áreas residenciais e para a produção agrícola, esta última vem ganhando mais espaço no Núcleo Rural Lago Oeste nos últimos anos.

Ainda encontra-se presente adjacente à região central da ReBio a Vila Basevi, uma vila que se instalou na região na década de 1970 por trabalhadores da Usina de Asfalto Basevi Engenharia que buscavam uma local de moradia próximo ao local de trabalho (SHIRAISHI, 2011).

De acordo com Fortes et al. (2007) os condomínios do Grande Colorado ocupam uma área aproximada de 350 ha, os lotes variam de $300 \mathrm{~m}^{2}$ a $1.000 \mathrm{~m}^{2}$ e têm cerca de 14.000 moradores. O Núcleo Rural do Lago Oeste ocupa cerca de 4.500 ha, suas chácaras apresentam área mínima de $2.000 \mathrm{~m}^{2}$ com algumas já parceladas em lotes menores, e cerca de 3.000 moradores. Levando-se em consideração que estes dados datam de 2007, o número de moradores atualmente é bem maior e os tamanhos dos lotes tendem a diminuir. A Vila Basevi tem uma área de cerca de 20 ha, com lotes de $250 \mathrm{~m}^{2}$ a $500 \mathrm{~m}^{2}$ e aproximadamente 2.700 moradores.

\subsection{A RESERVA BIOLÓGICA DA CONTAGEM}

A Reserva Biológica da Contagem é uma Unidade de Conservação de Proteção Integral, isso significa que tem o objetivo básico de preservar a natureza, sendo admitido apenas o uso indireto dos seus recursos naturais (IBRAM, 2014).

A ReBio da Contagem foi criada por meio de decreto sem número em 13 de dezembro de 2002, com o objetivo de assegurar a preservação do equilíbrio natural da diversidade biológica e dos processos ecológicos naturais (BRASIL, 2002). Suas terras são pertencentes à União e cedidas para o ICMBio, para administração, adotando as medidas necessárias à sua efetiva proteção e implantação. 
A ReBio da Contagem encontra-se localizada na Chapada da Contagem, ao norte do Distrito Federal e possui uma área total de 3.426,15 hectares. Ela limita-se ao sul com a rodovia DF 001 e o Parque Nacional de Brasília, a oeste com o Núcleo Rural Lago Oeste, a leste com os condomínios do Setor Habitacional Grande Colorado e Região Administrativa de Sobradinho II, e ao norte com a rodovia DF 150 (ICMBio, 2015; BRASIL, 2007) (Figura 1).

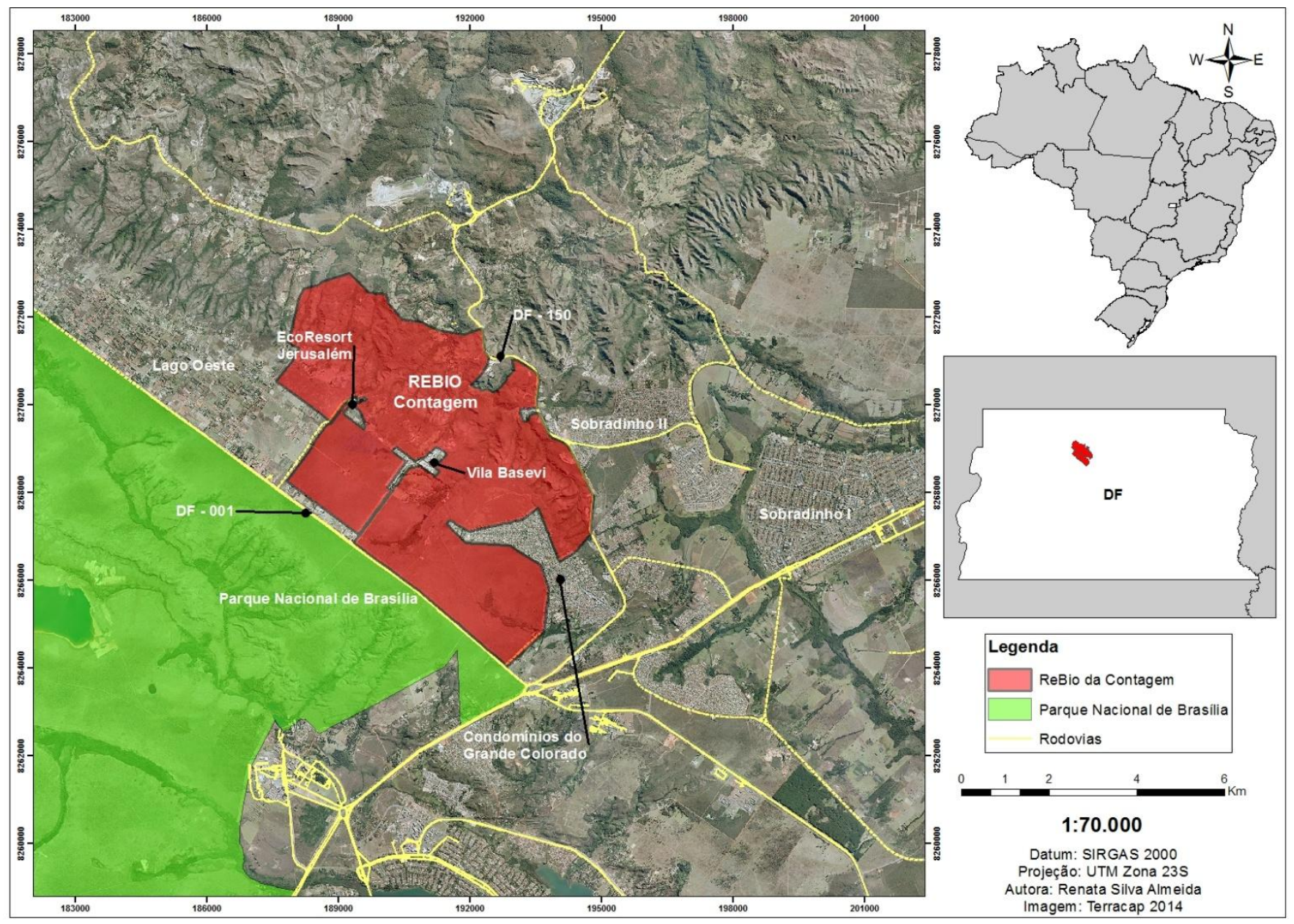

Figura 1. Localização da Reserva Biológica da Contagem.

Fonte: imagem Terracap (2014).

Seu território encontra-se inserido na APA de Cafuringa e esta inserida na APA do Planalto Central, que abrange a maior parte do Distrito Federal. A APA do Planalto Central foi criada mais com a intenção política de gestão territorial do DF, a fim de controlar o uso e ocupação do solo contra proliferação de assentamentos urbanos, invasões e parcelamentos irregulares de terras. Sendo assim, a localização espacial da ReBio da Contagem também faz parte de outras duas Áreas de Proteção Ambiental, isso demonstra a importância de se proteger 
mais efetivamente a região da Reserva (NETTO e CARDOSO, 2006). Além disso, a ReBio da Contagem também apresenta três Áreas de Proteção de Mananciais presentes em seu território, a APM do Torto, da Contagem e do Paranoazinho (Figura 2).

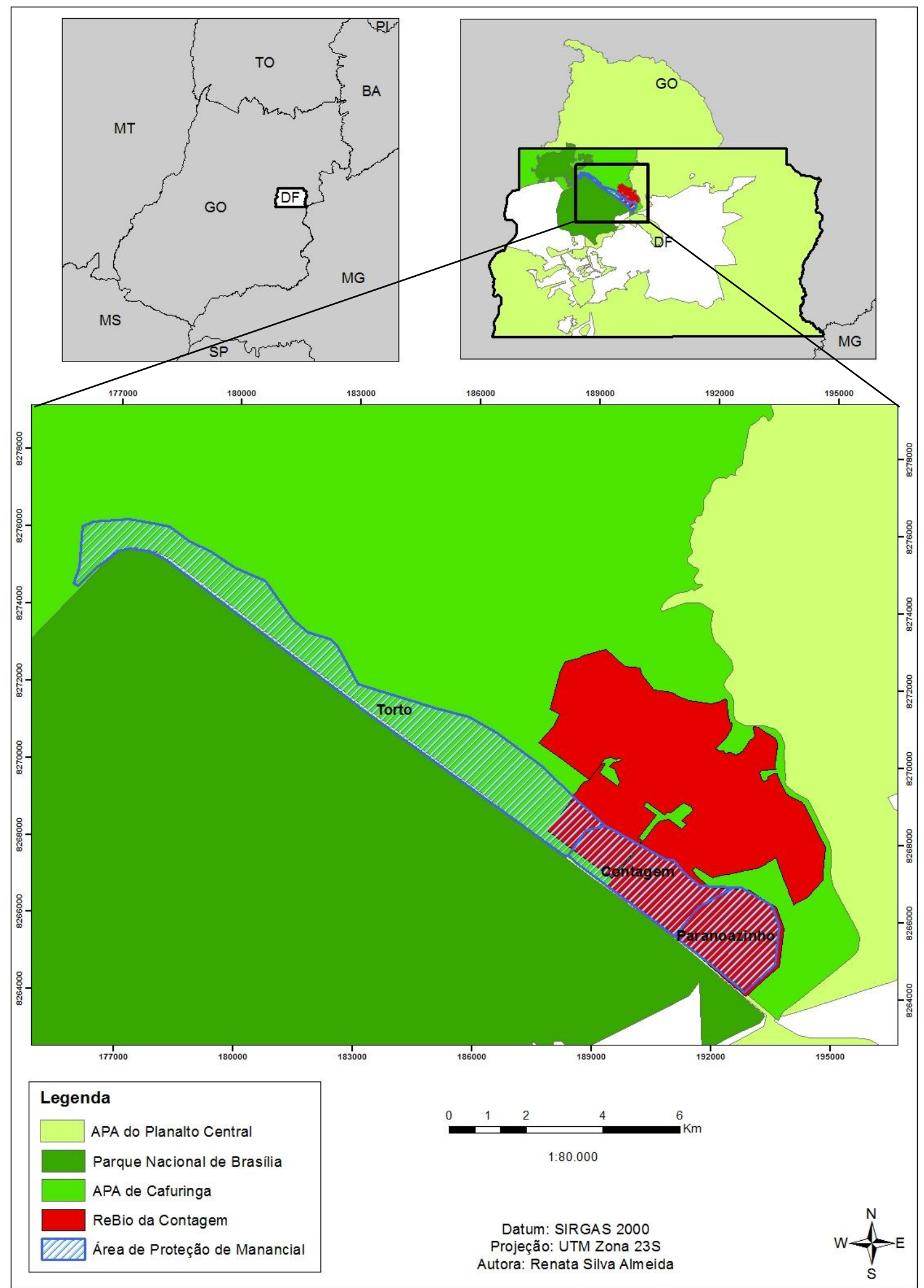

Figura 2. Localização da Reserva Biológica da Contagem em relação às áreas de conservação vizinhas.

Fonte dos dados: ICMBio (2015); Terracap (2010). 
A Reserva se encontra na região de altitude mais elevada Brasília, localiza-se no topo da Chapada da Contagem e conta com grande variedade de fitofisionomias do bioma Cerrado, que conforme Lopes et al. (2009), são nove ao total, pertencentes aos três tipos de formações de Ribeiro e Walter (1998). Nas formações florestais aparecem as Matas de Galeria; nas formações savânicas são encontrados Cerrado Típico, Cerrado Ralo, Cerrado Rupestre e Vereda; nas Formações Campestres, o Campo Sujo Seco, Campo Sujo Úmido, Campo Limpo Seco e Campo Limpo Úmido.

A ReBio da Contagem apresenta alta sensibilidade ambiental e também conta com a presença de um relevo mais acidentado na área da borda da Chapada, fator de grande relevância por sua fragilidade e para conservação das bacias e nascentes presentes no local, que recebem grandes volumes de águas pluviais e que favorecem a recarga dos aquíferos na região (SHIRAISHI, 2011). A UC também protege as nascentes do Ribeirão da Contagem e o Córrego Paranoazinho e tem função de corredor ecológico entre o Parque Nacional de Brasília, a Bacia do Rio Maranhão e Estação Ecológica de Águas Emendadas (LINS, 2012).

$\mathrm{O}$ fato da Reserva se encontrar inserida em meio a ocupações urbanas também reforça mais ainda seu papel conservador para a manutenção da biodiversidade, conexão com outras áreas de vegetação natural, proteção dos mananciais e para qualidade de vida da população de modo geral. Porém, mesmo com tamanha importância a área ainda apresenta poucas pesquisas e produções científicas desenvolvidas em seu território (LOPES et al., 2009).

Além de seu valor ecológico a área de Reserva também possui grande valor histórico na região. Objetos, estruturas e estradas reais do século XVIII são encontrados na Reserva, no local havia um posto fiscal da Coroa Portuguesa, o Posto Fiscal Contagem, que deu origem ao nome da Reserva. Por ele passavam mercadorias como escravos, gado, sal, carnes, pólvora para as minas de ouro e suprimentos para abastecimento dos moradores da região (VIEIRA JÚNIOR, 2009).

Porém, há vestígios da presença humana na área da Reserva de mais de seis mil anos a.C., são fósseis de grupos humanos pré-históricos encontrados no local por pesquisadores do Núcleo de Arqueologia do Instituto Goiano de Pré-História e Antropologia (IGPA) da Universidade Católica de Goiás (UCG), que identificaram três sítios arqueológicos préhistóricos, do período lítico (VIEIRA JÚNIOR, 2009). 


\subsubsection{CONFLITOS AMBIENTAIS NA REGIÃO DA REBIO DA CONTAGEM}

Apesar de ser uma UC de proteção integral, a ReBio da Contagem não se encontra imune a problemas, principalmente de cunho ambiental e social. Várias são as adversidades presentes em seu território e nas redondezas que afetam e influenciam negativamente a qualidade do meio ambiente e geram uma maior pressão sobre sua área.

Começando pela questão da expansão de ocupações nas redondezas da Reserva, que vêm ocorrendo há várias décadas e que somadas ao aumento da população do DF contribuem para maior especulação imobiliária, gerando o parcelamento de terras e a apropriação de modo desordenado e em sua maioria sem regularização. É recorrente o surgimento de condomínios horizontais na região, representando situações de grande pressão antrópica sobre a Reserva. Já são mais de 50 condomínios residenciais localizados nos setores habitacionais Grande Colorado e Contagem (LINS, 2012; TERRACAP, 2016), além das ocupações no Núcleo Rural Lago Oeste, na Vila Basevi e na Rua do Mato.

O antigo Eco Resort Jerusalém (Clube do Empresário) e as usinas de asfalto que já não funcionam no local, mas que ainda possuem uma estrutura instalada e mais a Vila Basevi, encontram-se localizados numa área limítrofe com a ReBio da Contagem, sendo a área da Vila e das usinas localizadas bem ao centro, no coração da Reserva e a do Clube mais a oeste, porém ambas instalações representam grandes recortes na poligonal da área da UC e ampliam o efeito de borda no local (Figura 1).

Vários problemas relacionados aos recursos hídricos surgem na região próxima à Reserva, devido às condições de instalação das residências e demais edificações. Em várias moradias, como as do Núcleo Rural Lago Oeste (NRLO) e Condomínios do Grande Colorado, a água é captada por meio de poços profundos que representam uma grande ameaça aos aquíferos, além do problema relacionado às fossas, este também presente na Vila Basevi. Sem saneamento, durante o período chuvoso as fossas transbordam e provocam a contaminação de águas superficiais e subterrâneas e causam problemas à saúde da população e a perda da qualidade dos recursos hídricos. Por conta das ocupações a impermeabilização dos solos também aumenta e provoca o rebaixamento do lençol freático e a diminuição da vazão das nascentes (HOROWITZ, 2003; FORTES et al., 2007; SANTANA et al., 2005).

Pelo fato do território abrigar várias nascentes do DF (Figura 11) e ainda abastecer a população de Sobradinho (SHIRAISHI, 2011), a problemática que envolve os recursos hídricos se torna muito mais preocupante na área da Reserva. Além disso, o crescente aumento 
populacional também aumenta o consumo de água, que excede a capacidade de suporte tanto para o abastecimento de água como para o esgotamento sanitário (NETTO, 2006). Também existe a presença de lotes instalados em locais impróprios para construções, onde se encontram lençóis freáticos superficiais e que ressurgem em épocas de chuva (HOROWITZ, 2003).

A questão das fossas que transbordam, de áreas com cultivo agrícolas como no NRLO, áreas industriais e a própria ocupação humana em si, também interferem na qualidade e contribuem para a exportação de cargas para os cursos d'água, como o nitrogênio que quando presente em forma de nitrato pode causar doenças como a meta-hemoglobinemia, em forma de amônia livre é tóxico para os peixes e quando em concentrações elevadas acarreta no consumo do oxigênio dissolvido na água, afetando desta maneira a vida aquática e implicações no tratamento de água e esgoto (VON SPERLING, 1995).

O processo de eutrofização, que pode causar danos à saúde humana, se refere ao crescimento excessivo de algas e ocorre em virtude de elevadas concentrações de nitrogênio e fósforo, muitas vezes provenientes de utilização de agrotóxicos e fertilizantes, junto a um manejo inadequado no solo, isto afeta a qualidade da água, sendo mais frequente em águas represadas como locais de captação para abastecimento. A exploração mineral e a presença de áreas degradadas também contribuem com a sedimentação de partículas inorgânicas nos cursos d'água, causando poluição dos recursos hídricos (ANA, 2005).

As ocupações nas redondezas da Reserva geram diversos agravantes ao ambiente ao redor, elas abrem estradas para facilitar o acesso às áreas ocupadas, que de início já degradam superfícies e promovem exploração de recursos ambientais como argila e cascalho laterítico para sua construção, que são retirados das usinas próximas ao local de construção (CORRÊA e BAPTISTA, 2006).

Com a ampliação das estradas o número de atropelamentos da fauna silvestre e os efeitos de borda também se amplificam, aumentam o número de ocupações e a poluição do ar, sem contar as estradas e trilhas abertas dentro da própria Reserva que facilitam o acesso da população a lugares proibidos, bem como de aventureiros da mountain bike e do motocross, que causam interferência no habitat de espécies de fauna que se assustam com a presença das pessoas e com o barulho das motos e fogem, às vezes definitivamente, de seu território, além de abrirem caminho para processos de erosão, entupimento de grotas e assoreamento de cursos d'água (NETTO, 2006).

A exploração de recursos minerais na região próxima à ReBio da Contagem também é um fator impactante ao meio ambiente. Em localidades bem próximas e até limítrofes à 
Reserva são encontradas fábricas de cimento e asfalto, além de várias cascalheiras, que desde os anos de 1970 se encontram presentes na região (HOROWITZ, 2003). Um exemplo é a fábrica de cimentos Basevi, que já não funciona mais no local, mas que foi responsável por trazer os trabalhadores, que migraram para a região da chapada e por lá instalaram suas moradias, ocupando uma área altamente sensível à perturbações.

Após o estabelecimento da APA da Cafuringa no ano de 1988, através do Decreto $\mathrm{n}^{\mathrm{o}}$ 11.123, a exploração mineral na região foi proibida, sendo permitida somente as que já existiam antes de sua criação, com exceção das usinas de asfalto Basevi e ETEC, que por se localizarem bem no interior da Reserva da Contagem, foram obrigadas a mudar de local em 2010 (SHIRAISHI, 2011).

Como consequências negativas comuns ocasionadas pela exploração mineral podem ser citadas as áreas que foram mineradas e não passam por processos de recuperação ambiental, estas acabam produzindo sedimentos que em períodos de chuva são carreados e provocam o assoreamento de corpos d'água, estas áreas também se tornam bem sugestivas para o despejo irregular de lixo e entulho. Além do mais as superfícies mineradas apresentam taxas de infiltração de água bem inferiores às áreas vegetadas (cerca de 10\% a 20\%), isso diminui o abastecimento da água subterrânea nos solos e aumentam o índice de escoamento (CORRÊA e BAPTISTA, 2006).

Outras áreas também afetadas pela mineração são as bordas de chapadas e áreas de recarga de aquíferos, onde pode ser encontrado cascalho laterítico, sendo que nestas áreas nem deveriam existir ações de exploração (CORRÊA e BAPTISTA, 2006). Como exemplo desta degradação no interior da própria Reserva é possível encontrar 12 cascalheiras abandonadas (SHIRAISHI, 2011).

Decorrente da crescente ocupação desordenada dessas áreas, muitas delas irregulares, diversos problemas e fatores de risco para sustentabilidade da ReBio Contagem são ocasionados, entre eles situações de desmatamento da vegetação natural para dar lugar à construção de moradias, despejo de lixo em locais inapropriados, como em cachoeiras e trilhas presentes na Reserva. O lixo contamina o solo e os recursos hídricos, bem como atrai a presença de roedores e outros transmissores de doenças.

Ocorrências de incêndios são causadas principalmente por queima de lixo, para sua eliminação das residências e para limpeza de terrenos, queimadas de regiões agropastoris, fogueiras, velas de rituais religiosos e pontas de cigarros acesos lançados próximos à vegetação e até por própria intenção maldosa de atear fogo na Reserva. As queimadas causam mortes de 
espécies animais e vegetais ou prejuízo em seu crescimento, alimentação e reprodução, poluição de cursos d'água e do ar, enfraquecimento e exposição dos solos (NETTO, 2006), tornando as áreas afetadas bastante vulneráveis e interferindo no equilíbrio ecológico.

O trânsito de pessoas na área da Reserva ocorre sem a ciência ou a preocupação desta se tratar de uma Unidade de Conservação de proteção integral e cujo acesso é restrito (BRASIL, 2000a). Muitas a frequentam como se fosse o quintal de suas casas: fazem caminhadas, passeios com cachorros e de bicicleta (VIEIRA JÚNIOR, 2009). Os cães inclusive representam um grande problema para a fauna silvestre, eles atacam os animais e competem por recursos, além de transmitir doenças aos mamíferos. Eles predam desde pequenos répteis até mamíferos de médio e grande porte, como tamanduás e antas (HOROWITZ, 2003).

Os moradores da Vila Basevi utilizam trilhas localizadas dentro da Reserva para cortar caminho em seu acesso aos condomínios do Grande Colorado e arredores. Há também a presença de outro público, mais frequente nos finais de semana e interessado em atividades recreativas, que visitam a ReBio da Contagem para caça, pesca, coleta de flora e tomar banhos de cachoeiras e as acessam por trilhas já abertas, sendo duas dessas cachoeiras mais frequentadas: a Cachoeira do Buriti, localizada próxima à Vila Basevi e a Cachoeira dos Deuses que fica próxima aos condomínios do Grande Colorado (LINS, 2012; SHIRAISHI, 2011). Além da utilização da Reserva como refúgio para criminosos que frequentemente assaltam e furtam residências nas redondezas e fogem para o interior da UC para escapar da atuação da polícia. Inclusive durante a realização do trabalho não foi possível ter acesso até as cachoeiras pelo risco de assaltos corriqueiros no local.

Devido à divergência de interesses entre a comunidade e a ReBio da Contagem, entre gestores e a população, situações de conflito ou aversão à proteção ambiental acometem a Unidade de Conservação. Como os moradores do Grande Colorado que não tiveram seus pedidos atendidos de uma área de 194 ha destinada para a criação de um parque ecológico para uso da população local, sentindo apenas as restrições imposta pela criação da UC e não os benefícios (NASCIMENTO, 2014).

A falta de conhecimento sobre a importância ecológica da região e do grande poder de interferência das ocupações e ações da população sobre o meio ambiente também prejudicam a conservação. Conforme pesquisa de Shiraishi (2011) que verificou que 44\% dos frequentadores da Reserva não sabem o que significa uma Unidade de Conservação e que apenas $34 \%$ tem conhecimento que não é permitido o acesso à mesma. 
Os fatores renda e educação também interferem nesse aspecto, na Vila Basevi, onde a maior parte das famílias é de baixa renda e a escolaridade da maioria da comunidade não chega à conclusão do ensino médio, poucos são os moradores que têm consciência do papel ecológico da Reserva e maneiras de protegê-la ou como evitar maiores prejuízos ambientais (LINS, 2012).

Algumas situações mais conflitantes na Reserva foram registradas conforme Figuras 3 e 4.

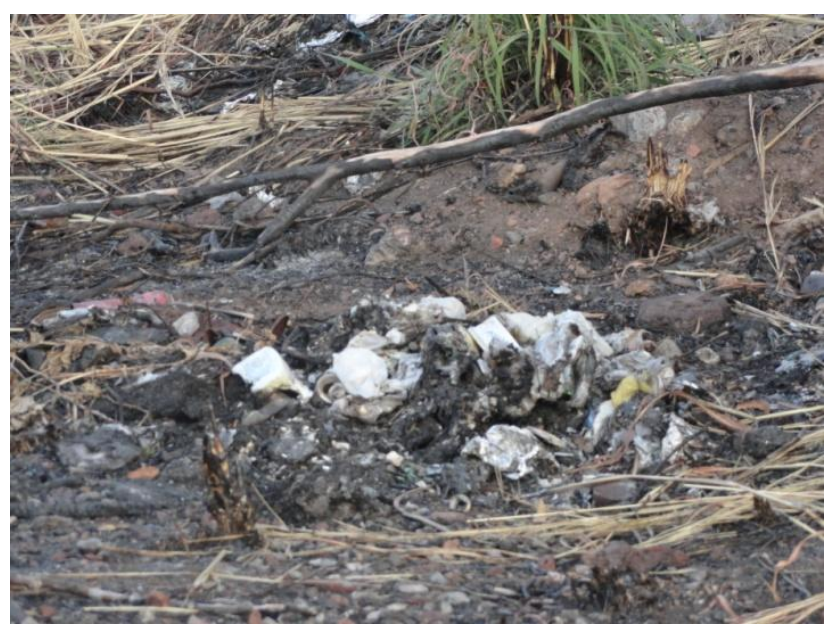

(A) Lixo incinerado às margens da Reserva.

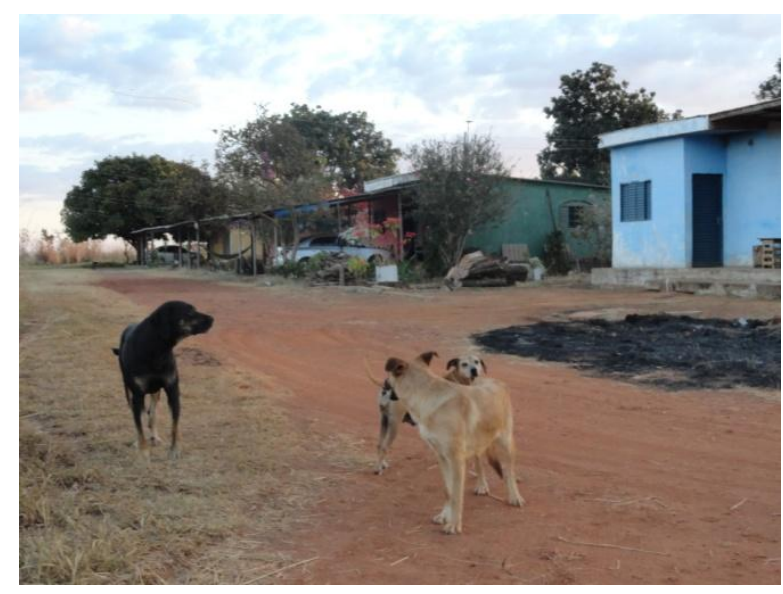

(C) Moradias, presença de cães domésticos, focos de queimadas, tudo isso no interior da Reserva.

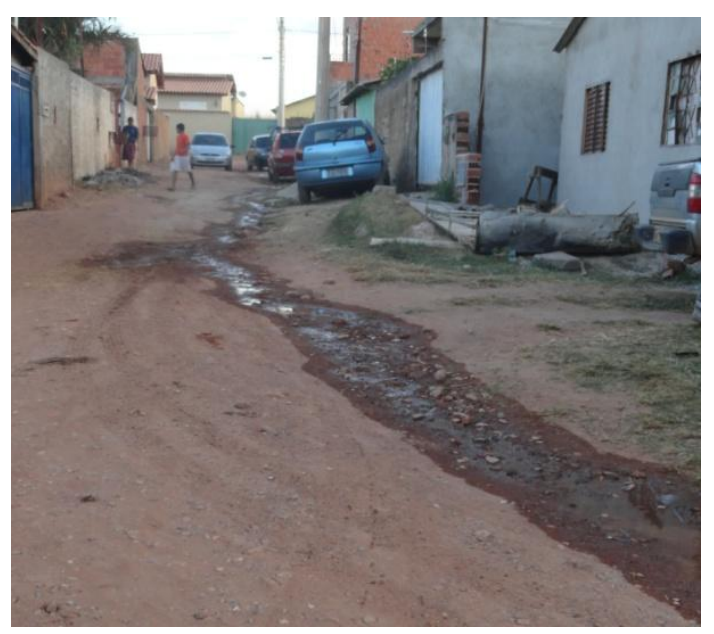

(B) Falta de saneamento na Vila Basevi

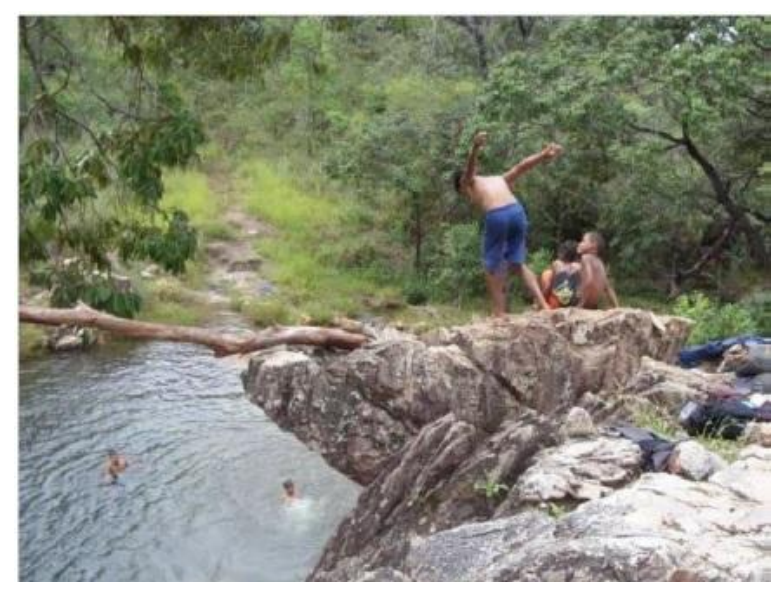

(D) Acesso ilegal à Cachoeira dos Deuses na Reserva.

Figura 3. Imagens da ReBio da Contagem e redondezas. Fonte: (A, B e C) Almeida (2016); (D) Shiraishi (2011). 


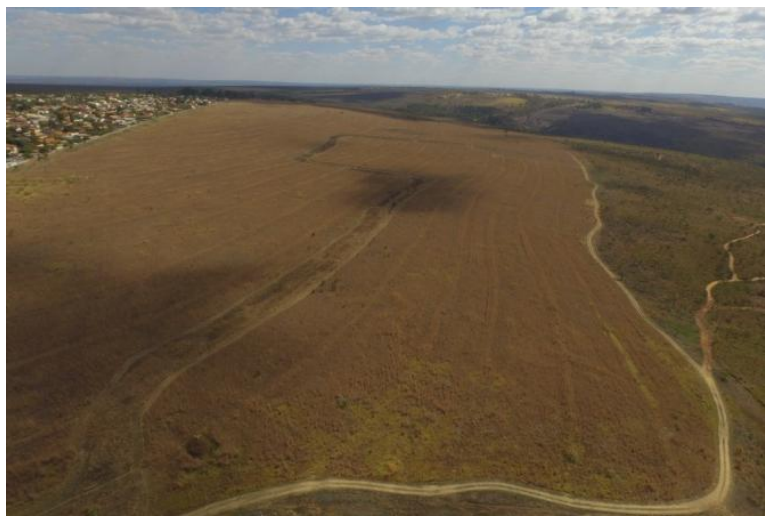

(E) Área de gramínea no interior da Reserva, usada anteriormente para plantio de soja.

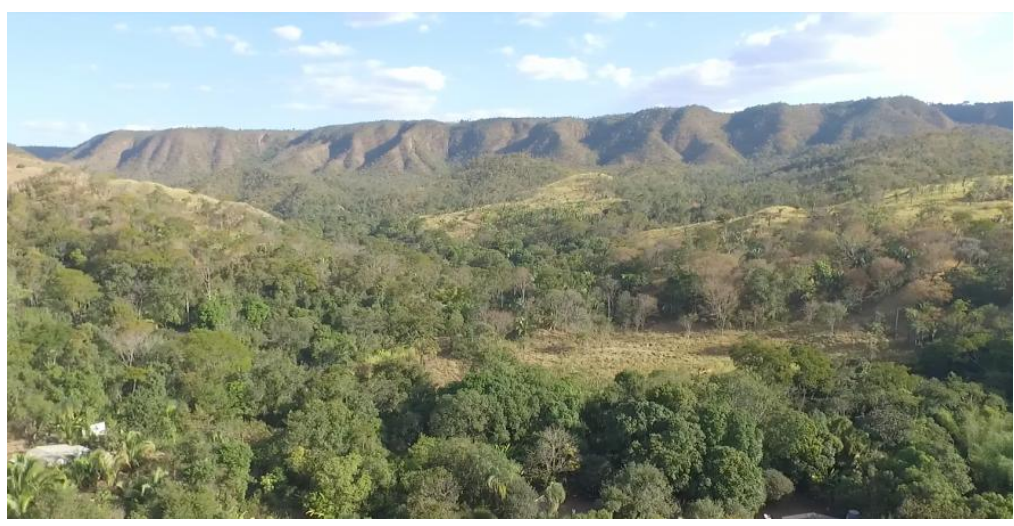

(F) Visão de uma parte da encosta da chapada na Reserva Biológica da Contagem.

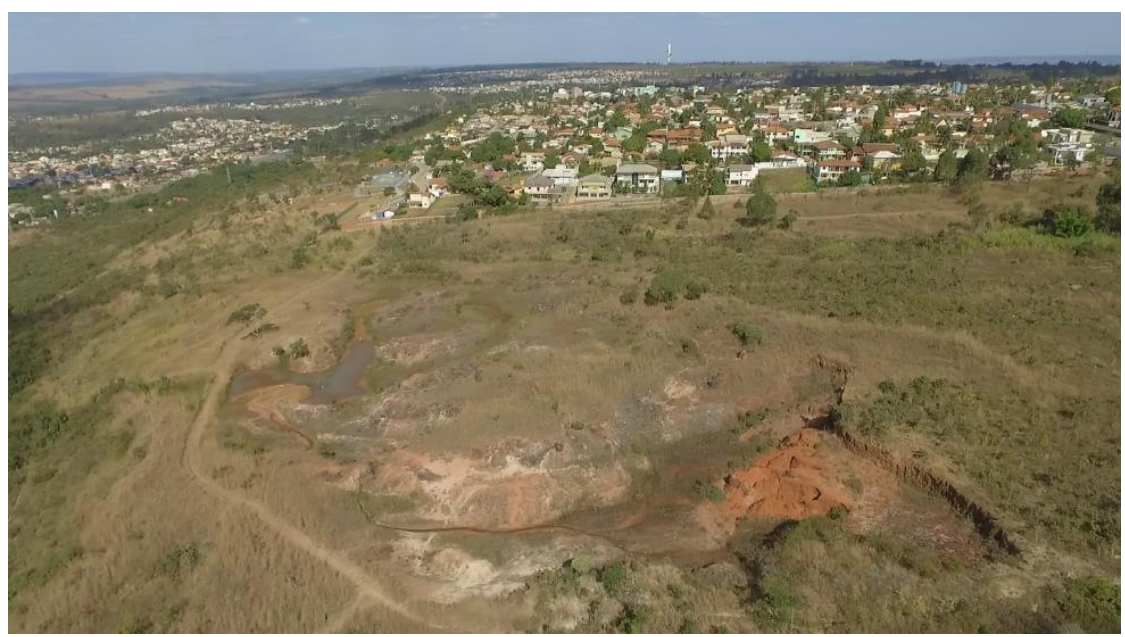

(G) Área de antiga exploração mineral na Reserva. Ao fundo casas dos Condomínios do Colorado.

Figura 4. Imagens da ReBio da Contagem e redondezas.

Fonte: (E, F e G) Sobral (2016).

\subsubsection{CLIMA}

O clima da ReBio da Contagem apresenta a mesma caracterização climática do DF, de acordo com a classificação de Köppen-Geiger: Tropical (Aw) com estação chuvosa no verão, com maiores índices de precipitação nos meses de novembro, dezembro e janeiro e um inverno seco principalmente nos meses de junho a agosto (CARDOSO, MARCUZZO e BARROS, 2014).

No entanto, devido a variações de temperatura ocasionadas por altitudes mais elevadas, como as que são encontradas no terreno da ReBio da Contagem, é possível ampliar essa 
classificação climática para três tipos (CODEPLAN, 1984; BAPTISTA 1998; BAPTISTA, 2006):

- Tropical (Aw): apresenta clima de savana, com temperatura do mês mais frio superior a $18^{\circ} \mathrm{C}$. Normalmente presente nos locais com altitudes abaixo de 1.00 metros.

- Tropical de Altitude (Cwa): a temperatura do mês mais frio é inferior a $18^{\circ} \mathrm{C}$ e o mês mais quente tem média superior a $22^{\circ} \mathrm{C}$. Tem maior ocorrência nos rebordos e escarpas intermediárias entre a chapada e os vales dissecados por redes de drenagem e em altitudes entre 1.000 e 1.200 metros.

- Tropical de Altitude (Cwb): a temperatura do mês mais frio é inferior a $18^{\circ} \mathrm{C}$ e o mês mais quente tem média inferior a $22^{\circ} \mathrm{C}$. Ocorre em altitudes acima de 1.200 metros.

\subsubsection{PRECIPITAÇÃO PLUVIOMÉTRICA}

A análise da precipitação pluviométrica da região da ReBio da Contagem é apresentada pela estação pluviométrica Brasília, sendo o regime de chuvas caracterizado por duas estações bem definidas, verão chuvoso e inverno seco, aspectos bem típicos na região do Cerrado. No Gráfico 1 é possível observar os valores de precipitação mais elevados nos meses de verão e a redução que vai ocorrendo a partir de janeiro, até atingir os menores valores durante o inverno, retomando o aumento das precipitações a partir do mês de agosto.

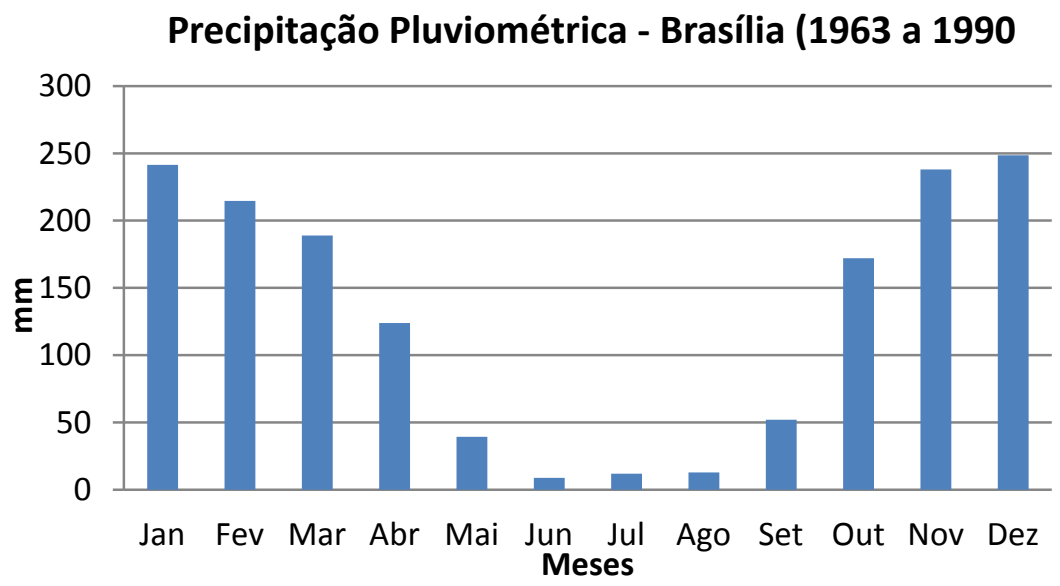

Gráfico 1. Distribuição anual dos totais mensais da estação Brasília.

Fonte: Baptista (1998) 
No mapa de isoietas apresentado na Figura 5 é possível observar melhor as precipitações em médias anuais, obtidas da interpolação de dados pluviométricos, pode-se notar que a região da área de estudo, apresenta elevadas precipitações, as maiores do DF.

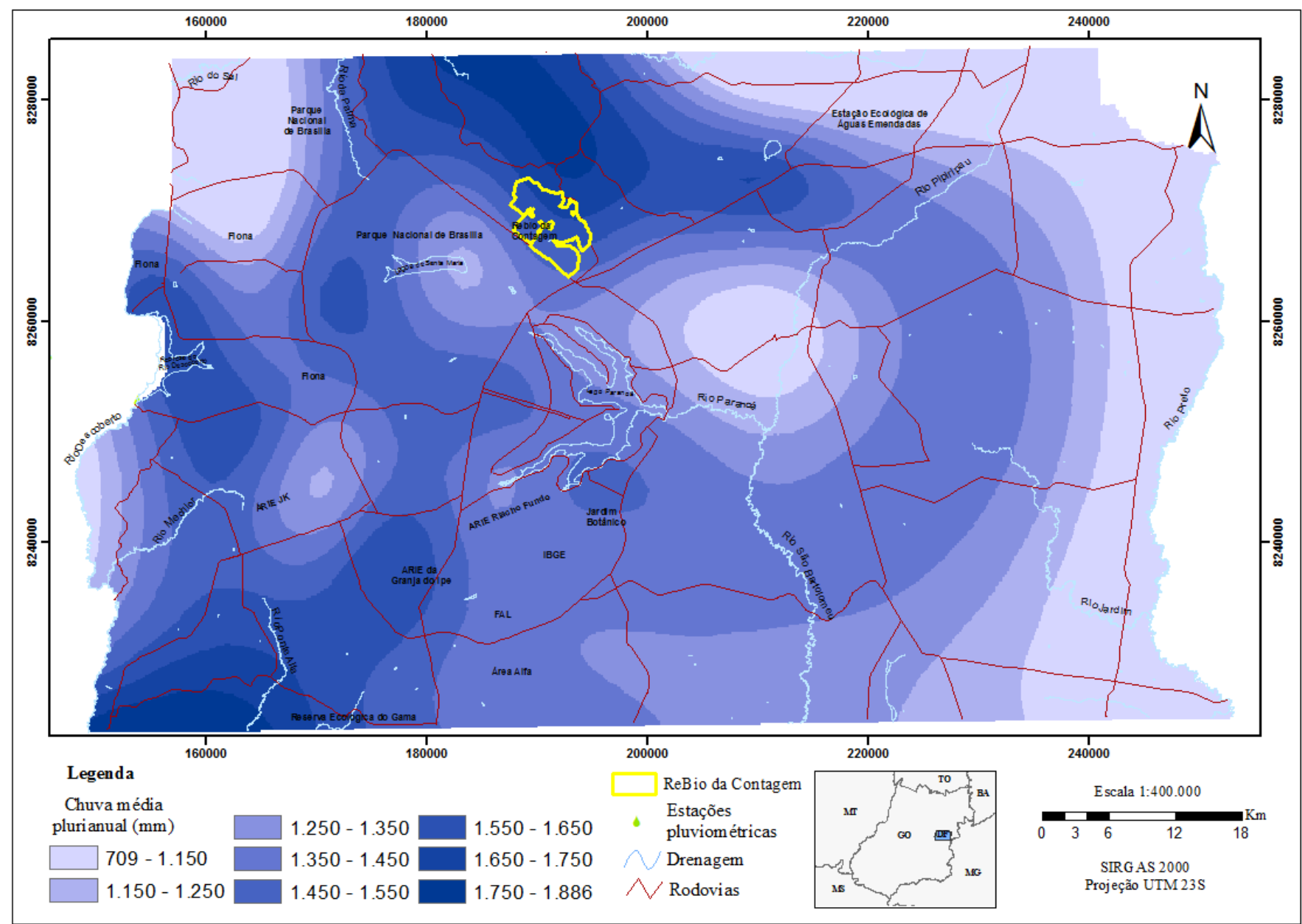

Figura 5. Mapa de isoietas do Distrito Federal, construído com dados de 42 postos pluviométricos. Fonte: Gonçalves; Roig e Campos (2009), com adaptações.

\subsubsection{GEOLOGIA}

A geologia também é um aspecto bastante relevante de abordagem na área de estudo e que exerce controle sobre elementos da paisagem, como o relevo, tipos e fertilidade de solos, os minerais presentes e do clima através de barramentos de massas úmidas sobre as bordas das chapadas e das áreas mais elevadas, concentrando as chuvas sobre estas regiões. De modo indireto a geologia também controla o meio biótico, através da densidade biomassa controlada pelos solos, que juntamente com o relevo também interferem no controle de refúgios e corredores naturais de fauna (CAMPOS, 2006). 
As formações geológicas são divididas em grupos, de acordo com os tipos de rochas encontradas e a idade das mesmas. $\mathrm{Na}$ área da ReBio da Contagem são encontradas rochas pertencentes ao grupo litológico Paranoá.

As rochas do grupo Paranoá datam do período Meso-Neoproterozóico, com idade de sedimentação entre 950 a 1350 milhões. Este grupo foi denominado Paranoá inicialmente por Andrade Ramos em 1958, devido às camadas de quartzitos puros aflorantes na região de Brasília, sendo incluídos no Grupo Bambuí, somente em 1995 Faria e Dardenne separaram a Formação Paranoá do Grupo Bambuí, caracterizando-o como uma sequência deposicional em ambiente marinho, que foi subdividida em doze fácies litológicas agrupadas em quatro grandes ciclos sedimentares, dentre as quais as Unidades Q3, R4 e PC ou PPC, que são encontradas na área de estudo (Figura 6).

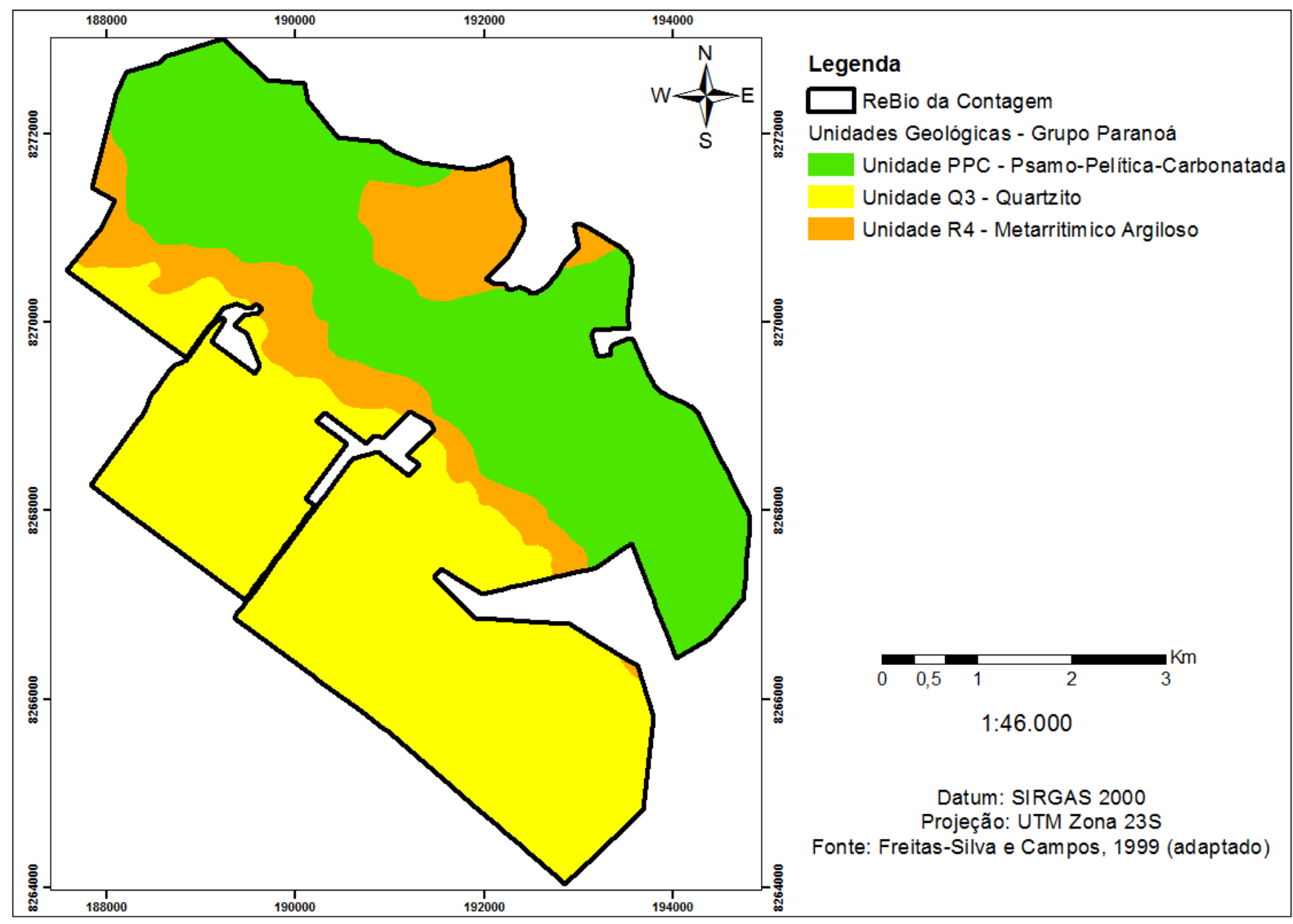

Figura 6. Unidades Geológicas da ReBio da Contagem.

A Unidade Q3 é composta por quartzitos finos a médios, de coloração branca ou cinza, silificados e com bastantes estratificações e fraturas. $\mathrm{O}$ fato de serem silificados contribui para que sofram menos alterações devido à ação dos agentes biológicos e abióticos (chuva, calor, 
vento) e para menor propensão ao intemperismo. São encontrados na área plana da Chapada da Contagem e sustentam seu relevo em cotas superiores a $1.200 \mathrm{~m}$. Os quartzitos apresentam essa característica de serem bastante maciços, mas se sofrem alterações formam solos arenosos, que são exporados pela construção civil (FREITAS-SILVA e CAMPOS, 1998; CAMPOS, 2006).

A Unidade R4 é composta pela alternância de materiais sílticos e argilosos, sendo assim denominada metarritmito argiloso. Também apresenta finos estratos de quartzitos cinza, amarelados, rosados ou avermelhados. Apresentam entre suas estruturas sedimentares estratos plano-paralelos, laminações cruzadas, truncadas por ondas e hummockys (irregulares e convexas), (FREITAS-SILVA e CAMPOS, 1998).

A Unidade PC (pelito-carbonata) ou PPC (psamo-pelito-carbonatada) é composta por rochas arenosas, argilosas, calcários e dolomitos. Sendo cerca de 85\% composta por metassiltitos argilosos, bastante laminados e de coloração cinza, até amarelado e rosado quando alterados. Ocupando $10 \%$ da sua composição está a parte carbonática, constituída por calcários, dolomitos e margas (calcita, dolomita e material detrítico), são dispostas em formas de lentes, podendo chegar a $200 \mathrm{~m}$ de espessura e de coloração acinzentada. Os $5 \%$ restantes correspondem às rochas arenosas, compostas de quartzitos finos a grossos de cor preta e grãos esféricos (CAMPOS, 2006).

\subsubsection{GEOMORFOLOGIA}

De acordo com Novaes Pinto (1994), a região do DF é dividida em 13 unidades geomorfológicas, agrupadas em 3 tipos de paisagem, típicos da região do Cerrado, sendo a maior parte da região da ReBio da Contagem é classificada como Região de Chapada, que apresenta topografia plana e plano-ondulada e desenvolve-se sobre quartzitos. A Chapada da Contagem é a unidade geomorfológica mais elevada do DF com cotas médias de 1200m. Uma menor parte é classificada como Região Dissecada de Vale e corresponde às depressões litológicas de resistências variadas, ocupadas pelos principais rios da região (Figura 7). 


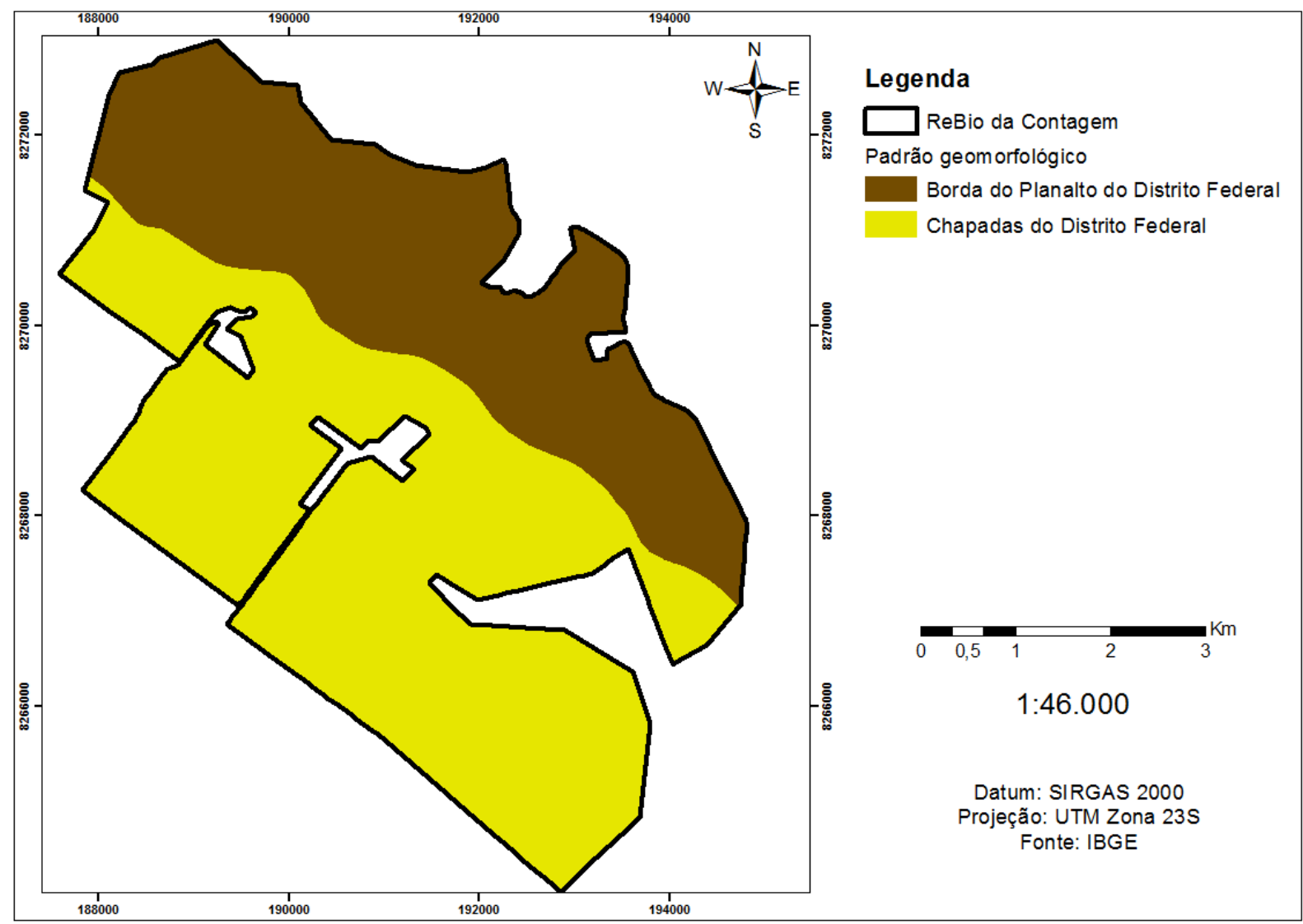

Figura 7. Padrão geomorfológico da ReBio da Contagem. A região de Chapadas do Distrito Federal corresponde ao aplainamento por pediplanação e a Borda do Planalto do Distrito Federal corresponde à dissecação.

A Reserva Biológica da Contagem situa-se no topo da Chapada da Contagem, um dos pontos mais altos do DF. Sua altitude varia de cerca de $1000 \mathrm{~m}$ à $1200 \mathrm{~m}$ de acordo com o BRASIL (2007), mas é possível observar na Figura 8 alguns trechos de 900m podendo chegar à 1300m. Tamanha variação de altitude gera uma declividade acentuada em seu terreno, podendo chegar à inclinações de mais de $60^{\circ}$ (Figura 9). Se a presença de inclinações mais abruptas por um lado reduzem a tendência à ocupação, por outro aumentam o fator de risco à susceptibilidade à erosão e lixiviação dos solos e contribuem para a grande sensibilidade e importância geológica da região.

A Reserva encontra-se numa das porções mais elevadas do Planalto Central. Correspondem ao último remanescente das superfícies de aplainamento formadas pelos ciclos de erosão Sulamericano, ocorridos entre o Terciário Inferior e Médio, e o ciclo Velhas, entre o Terciário Médio e Superior (KING, 1956; BARBOSA et al., 1969).

Mas, de acordo com o estudo da evolução geomorfológica da Codeplan (1984), as superfícies aplainadas presentes na ReBio da Contagem, ou pediplanos, foram geradas ainda no Cretáceo. São áreas de chapadas, chapadões e interflúvios tabulares e apresentam como 
características o clima seco, onde predominam os processos de desagregação de rochas, além de apresentarem altitudes entre 950 a $1400 \mathrm{~m}$, que devido a estas elevações constituem divisores dos rios São Bartolomeu e Preto (MARTINS e BAPTISTA, 1998).

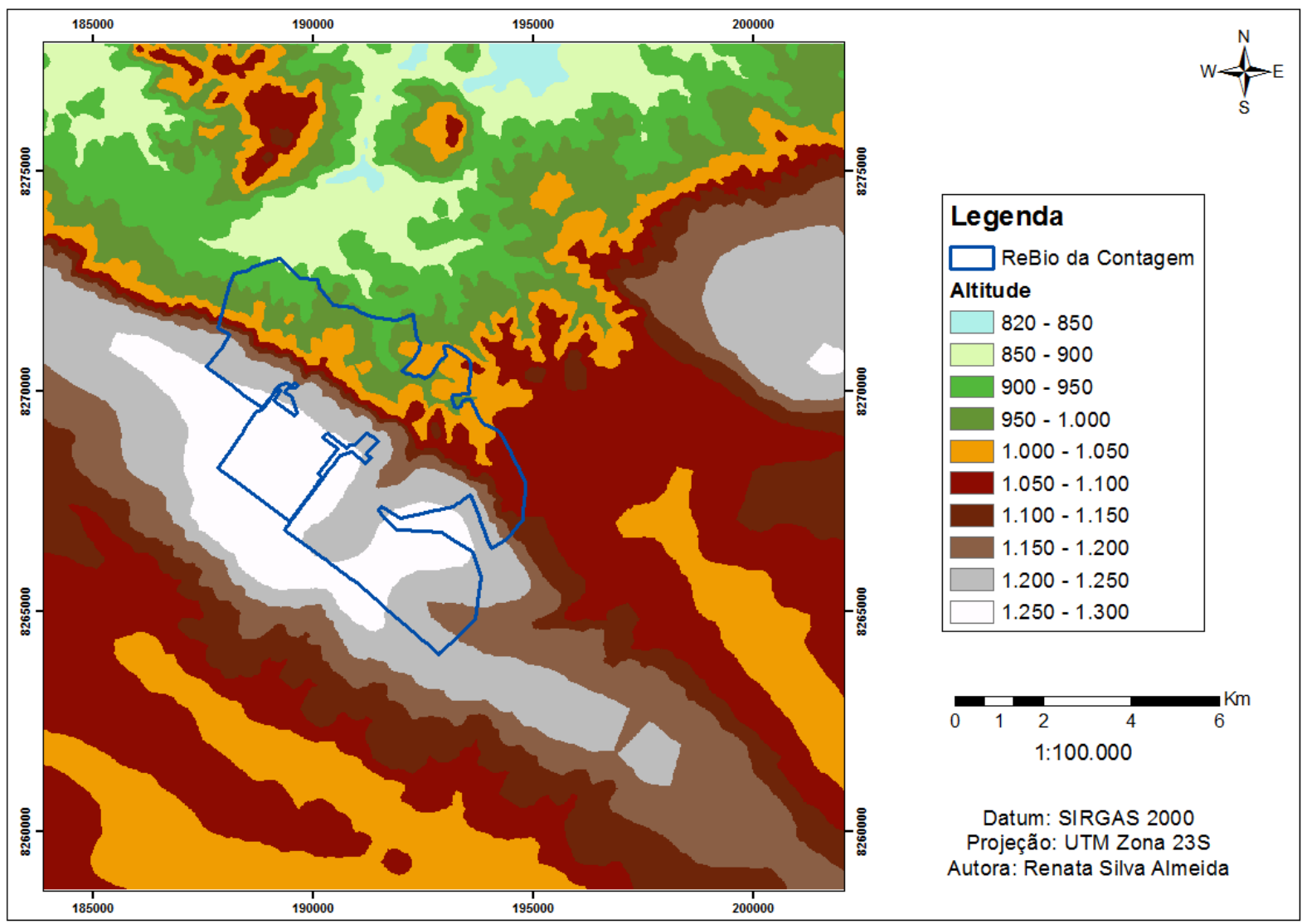

Figura 8. Mapa hipsométrico da Reserva Biológica da Contagem e do seu entorno.

Fonte dos dados: Terracap (2010). 


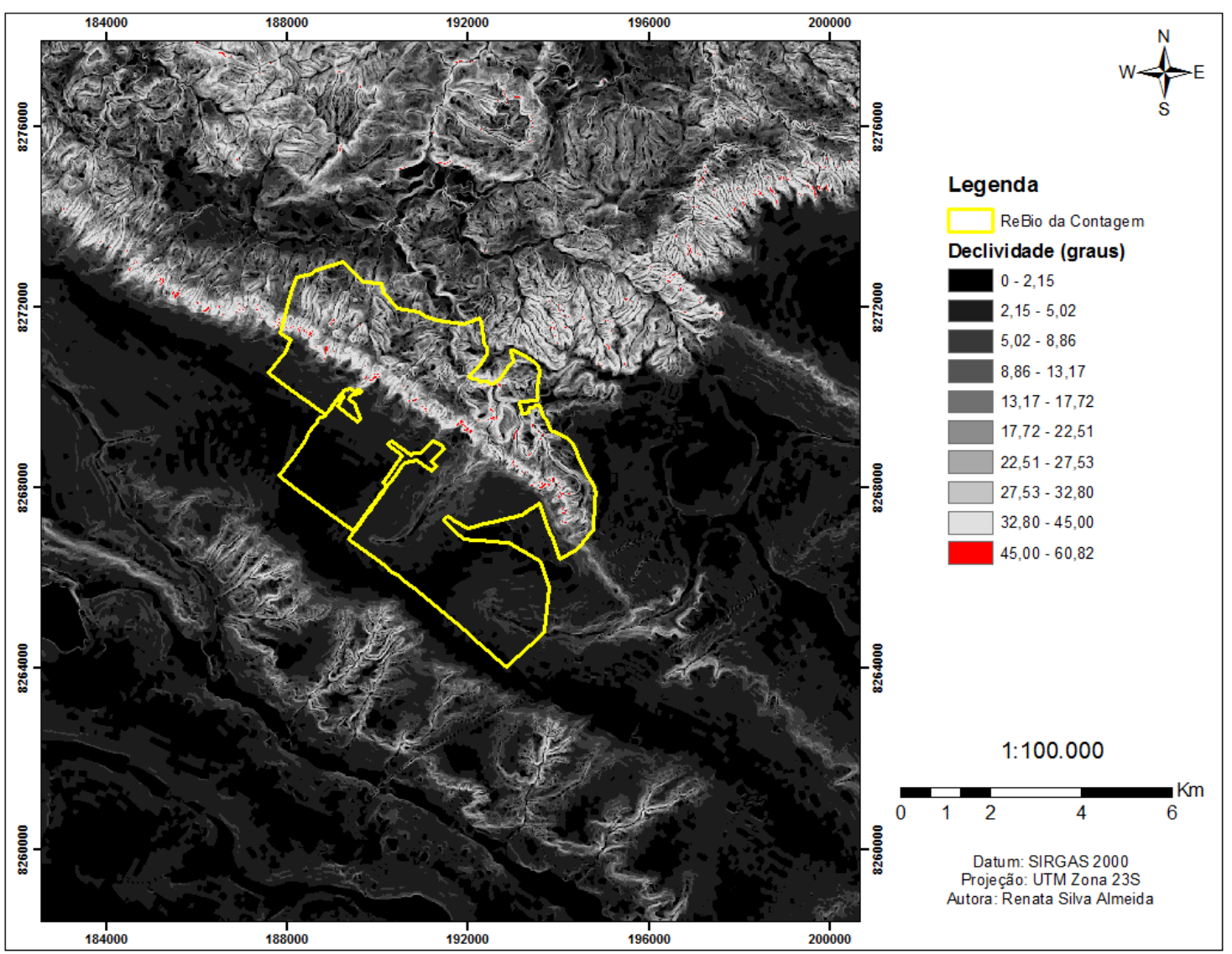

Figura 9. Mapa de declividade da Reserva Biológica da Contagem e seu entorno. Destaque para as áreas com declividade acima de $60^{\circ}$.

Fonte dos dados: Terracap (2010).

\subsubsection{PEDOLOGIA}

Os solos também possuem importância do ponto de vista ambiental, pois são um reflexo de aspectos ambientais, como clima, material de origem, organismos, relacionados com as formas de relevo que são decorrentes de processos evolutivos (REATTO et al., 2006).

$\mathrm{Na}$ área de estudo são encontrados os seguintes tipos de solo: Cambissolo, Espodossolo, Latossolo Vermelho, Latossolo Vermelho-Amarelo, Nitossolo, Plintossolo e Solos Hidromórficos Indiscriminados (Figura 10), que serão descritos a seguir, de acordo com os trabalhos da Embrapa (1998, 2004 e 2006). 


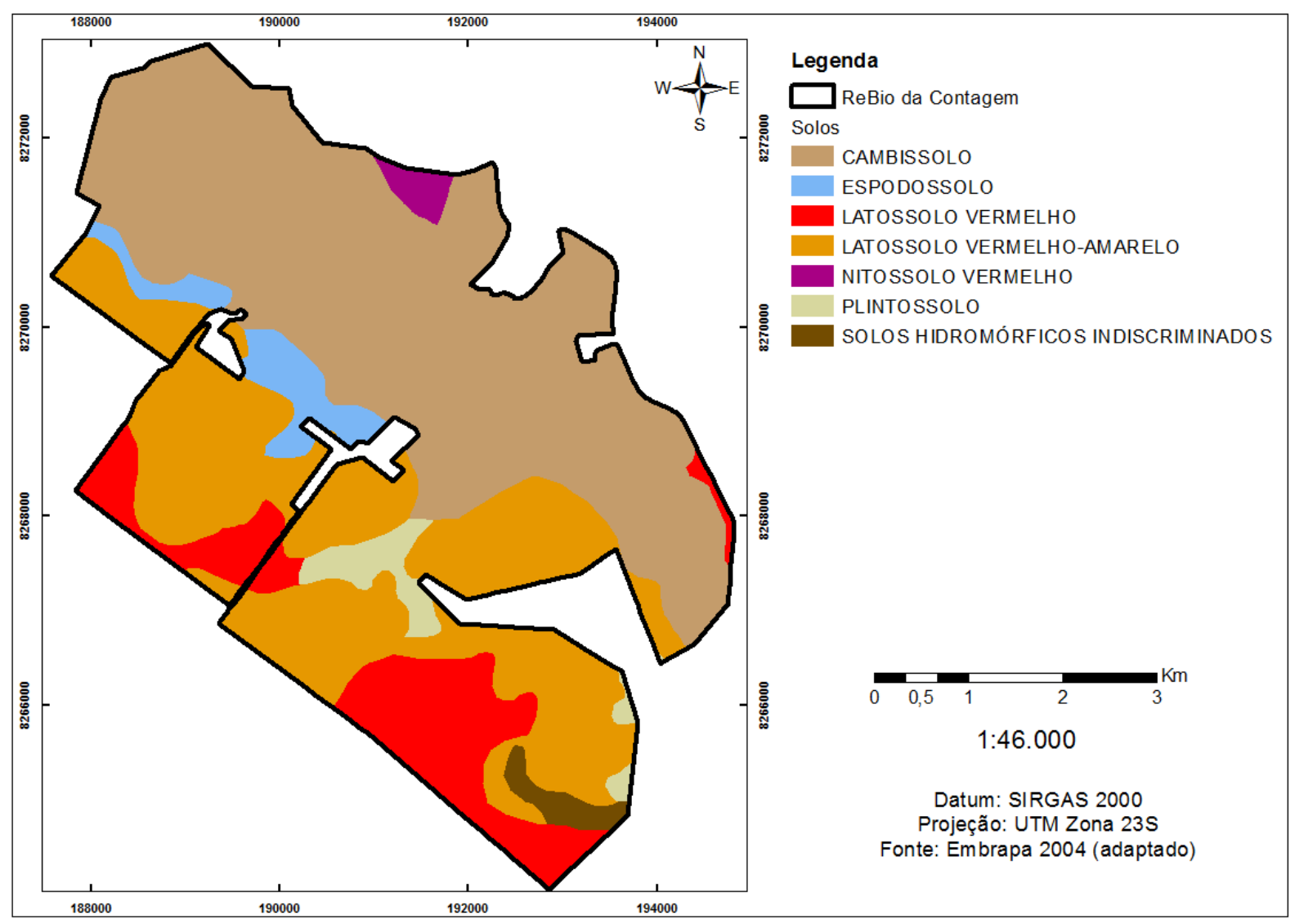

Figura 10. Mapa de solos da ReBio da Contagem.

Cambissolos são solos que apresentam minerais primários facilmente intemperizáveis, altos teores de silte, que indicam baixo grau de intemperização. Seu horizonte subsuperficial, B incipiente, é submetido à pouca alteração física e química. Apresentam coloração brunoamarelada no horizonte superficial e vermelho-amarelada no subsuperficial, são distróficos em função do material de origem e do clima local e variam de rasos a profundos (0,2 a $1 \mathrm{~m})$.

São associados à vegetação de cerrado típico, floresta, cerrado rupestre e ocorrem em relevos mais movimentados, ondulados e íngremes, sendo bem aplicados em áreas de preservação permanente.

Espodossolos também fazem parte do grupo de solos Hidromóficos Indiscriminados, são solos hidromórficos de textura bastante variável podendo apresentar consistência plástica e pegajosa quando muito argilosos. Podem ser ricos ou pobres em bases ou com altos teores de alumínio, devido à localização em áreas sujeitas a contribuições de material transportado de posições mais elevadas. Apresentam drenagens dos tipos: mal ou muito mal drenadas, onde ocorre espessa camada escura de matéria orgânica mal decomposta sobre uma camada acinzentada (gleizada), resultante de processos de redução do ferro. Possuem horizonte A bem 
desenvolvido e o espodossolo apresenta um horizonte B espódico subjacente a um horizonte A ou E.

Ocorrem em torno de drenagens, pequenos córregos, na base de lençóis freáticos, cabeceiras de rios e depressões sujeitas à inundações, em relevos planos a ondulados. São geralmente associados à vegetação de mata de galeria, vereda e campo limpo úmido e são extremamente importantes para conservação de águas e na preservação de Reservatórios hídricos da região.

Os Latossolos são solos altamente intemperizados e que concentram minerais secundários do grupo da caulinita, óxidos, hidróxidos e oxi-hidróxidos de $\mathrm{Fe}$ e $\mathrm{Al}$ como hematita, goethita, gibbsita e outros, com destaque para o quartzo que por apresentar forte resistência ao intemperismo, conserva-se como mineral primário residual no perfil de alteração. São solos minerais, não hidromórficos, profundos (normalmente $>2 \mathrm{~m}$ ), com horizonte $\mathrm{B}$ latossólico muito espesso (> $50 \mathrm{~cm}$ ), alta permeabilidade de água, distróficos, ácidos, com baixa a média capacidade de troca catiônica.

O Latossolo Vermelho tem a cor bruno-avermelhada escura predominante, ocorre nos topos das chapadas e geralmente associado à vegetação de cerrado típico e cerradão. $\mathrm{O}$ Latossolo Vermelho-Amarelo ocorre principalmente nas bordas das chapadas e em superfícies planas abaixo dos topos, sempre próximo ao Latossolo Vermelho, está geralmente associado à vegetação de cerrado típico, campo limpo e campo sujo e se diferencia do Latossolo Vermelho quanto à cor do horizonte B que é mais amarelada.

Nitossolos são solos derivados de rochas calcárias, eutróficos, com saturação por bases em torno de $80 \%$, bastante porosos e com boa drenagem. Apresentam estrutura bem desenvolvida no horizonte B nítico e coloração vermelho escuro com tendência arroxeada e textura argilosa, com reduzido gradiente textural entre o horizonte A e B. Ocorrem em relevos e porções média e inferior de encostas onduladas e fortemente onduladas, e geralmente estão associados à vegetação de mata seca semidecídua.

Os Plintossolos são solos minerais, hidromórficos, com grande limitação à percolação de água. São distróficos e com alto ou baixo teor de carbono orgânico no horizonte superficial e apresentam horizonte subsuperficial (plíntico) de coloração variegada, com manchas avermelhadas (plintitas).

São encontrados em situações de alagamento temporário, que geram um escoamento lento, em relevo plano e suave-ondulado, em áreas deprimidas e em encostas onde há 
importante movimentação lateral de água. São geralmente associados à vegetação de mata de galeria, vereda e campo limpo úmido.

\subsubsection{HIDROGRAFIA}

A hidrografia do Distrito Federal apresenta uma enorme variedade de mananciais, pequenos cursos d'água sendo a grande maioria destes com nascentes nos topos da Chapada Contagem-Rodeador (CCR), na qual a maior parte da área da ReBio da Contagem está contida e que tem grande favorabilidade à recarga de aquíferos (FORTES et al., 2007). É neste contexto que o DF também é conhecido como "berço das águas", por nele se localizarem nascentes de algumas das principais bacias hidrográficas do país.

A ReBio da Contagem encontra-se inserida entre as Bacias Hidrográficas do Maranhão (Região Hidrográfica Tocantins/Araguaia) e do São Bartolomeu (Região Hidrográfica Paraná), apresentando em sua área um trecho da divisão de duas das mais importantes bacias do país. Seus limites descrevem uma poligonal que engloba as cabeceiras do Ribeirão da Contagem e do Córrego Paranoazinho, respectivamente, e parte de suas microbacias, onde existem duas captações de água responsáveis pelo abastecimento público da cidade de Sobradinho (BRASIL, 2002). A região apresenta além destes outros pequenos córregos e nascentes que alimentam suas respectivas bacias. Somente uma pequena parcela da área da ReBio da Contagem encontra-se na Bacia do Lago Paranoá (Unidade Hidrográfica Santa Maria / Torto) (Figura 11). 


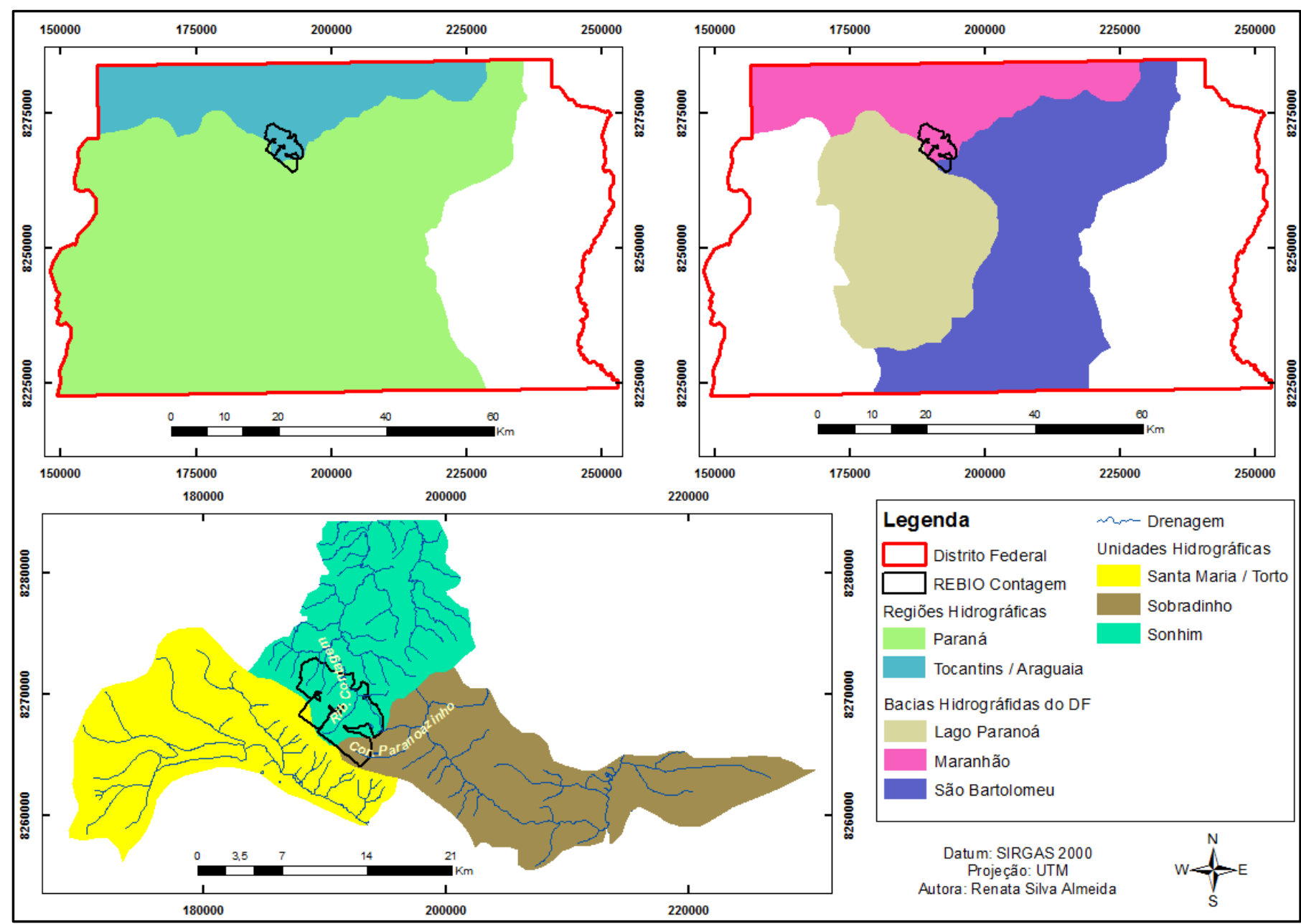

Figura 11. Mapa hidrográfico da ReBio da Contagem.

\subsubsection{HIDROGEOLOGIA}

O Distrito Federal, no contexto brasileiro, se localiza na Província Hidrogeológica do Escudo Central, que é extensamente dominada por aquíferos fraturados cobertos por mantos de intemperismo em suas rochas e solos, que apresentam características físicas e espessuras variáveis. O DF se diferencia em dois grandes grupos de aquíferos: Domínio Aquífero Fraturado e Domínio Aquífero Poroso, que serão descritos a seguir baseados em Campos e Freitas (1998). Devido à grande variação das unidades litoestratigráficas, os domínios apresentam subdivisões (Tabela 2). 
Tabela 2. Resumo da classificação dos Domínios, Sistemas/Subsistemas aquíferos do Distrito Federal com respectivas vazões médias.

\begin{tabular}{|c|c|}
\hline AQUÍFERO (Sistema/Subsistema) & MÉDIAS DAS VAZÕES (L/h) \\
\hline \multicolumn{2}{|c|}{ AQUÍFEROS DO DOMÍNIO POROSO } \\
\hline SISTEMAS $\mathbf{P}_{1}, \mathbf{P}_{2}, \mathbf{P}_{3}$ e $\mathbf{P}_{4}$ & $<800$ \\
\hline \multicolumn{2}{|c|}{ AQUÍFEROS DO DOMÍNIO FRATURADO } \\
\hline \multicolumn{2}{|c|}{ SISTEMA PARANOÁ } \\
\hline Subsistema S/A & 12.700 \\
\hline Subsistema A & 4.390 \\
\hline Subsistema $\mathbf{Q}_{\mathbf{3}} / \mathbf{R}_{\mathbf{3}}$ & 12.200 \\
\hline Subsistema $\mathbf{R}_{\mathbf{4}}$ & 6.150 \\
\hline Subsistema PPC & 9.100 \\
\hline \multicolumn{2}{|c|}{ SISTEMA CANASTRA } \\
\hline Subsistema $\mathbf{F}$ & 7.500 \\
\hline Subsistema $\mathbf{F} / \mathbf{Q} / \mathbf{M}$ & 33.000 \\
\hline SISTEMA BAMBUÍ & 5.210 \\
\hline SISTEMA ARAXÁ & 3.150 \\
\hline
\end{tabular}

Fonte: Campos e Freitas (1998).

O Domínio Poroso apresenta aquíferos onde a água ocupa os espaços entre os minerais que compõem as rochas, sendo no caso do DF representado pelo manto de alteração das rochas (solos). São compostos por solos que podem chegar a 80 metros de espessura, geralmente homogêneos, com sistema de águas subterrâneas rasas e aproveitados por poços rasos. São aquíferos susceptíveis à contaminação por agentes externos, sendo normalmente isolados em sistemas de abastecimento público.

Este domínio se divide em 4 sistemas de acordo com a espessura saturadas e condutividade hidráulica: P1, P2, P3 e P4, sendo encontrados na ReBio da Contagem os sistemas P1, P3 e P4 (Figura 12). Os sistemas P1 e P3 apresentam espessuras de mais de 5 metros e condutividade hidráulica alta e baixa, respectivamente. O sistema $\mathrm{P} 4$ apresenta espessura geralmente inferior a 1 metro e condutividade hidráulica baixa.

Neste domínio se originam os processos de recarga dos aquíferos (rasos e profundos) a partir da infiltração pluviométrica e colabora com a manutenção da perenidade de drenagens no período de recessão de chuvas. 
O Domínio Fraturado apresenta aquíferos onde a água ocupa espaços de descontinuidades em planos de fraturas, microfraturas, diáclases, juntas, zonas de cisalhamento e falhas. São aquíferos fortemente heterogêneos e anisotrópicos, compondo sistemas de águas subterrâneas profundas, são geralmente limitados a profundidades pouco superiores a 250 metros, sendo sua condutividade hidráulica controlada principalmente pela densidade das descontinuidades do corpo rochoso.

Os parâmetros hidrodinâmicos variam muito de acordo com o tipo de rocha e os aquíferos. São aproveitados em poços tubulares profundos e suas águas subterrâneas apresentam exposição à contaminação atenuada, uma vez que os aquíferos do Domínio Poroso que os sobrepõem funcionam como um filtro depurador natural, protegendo as águas mais profundas. Sua recarga se dá através do fluxo vertical e lateral de águas de infiltração a partir da precipitação pluviométrica, sendo a morfologia da paisagem um fator controlador importante das principais áreas de recarga regionais.

Na região da ReBio da Contagem são encontrados os sistemas aquíferos Paranoá e os subsistemas: $\mathrm{R}_{3} / \mathrm{Q}_{3}, \mathrm{R}_{4}$ e PPC, com médias de vazões de 12.200, 6.150 e 9.100 1/h, respectivamente (Figura 12).

Pelo fato do Distrito Federal estar situado em um alto regional sem a presença de grandes drenagens superficiais e sendo um divisor natural de três grandes bacias hidrográficas, das quais a ReBio da Contagem está presente em duas, as águas subterrâneas têm função estratégica na manutenção de vazões dos cursos superficiais e no abastecimento de núcleos rurais, urbanos e condomínios situados fora do Sistema Integrado de Abastecimento da Companhia de Saneamento de Brasília - CAESB, bem como em áreas onde sem sistemas alternativos de captação de pequenas drenagens (CAMPOS e FREITAS, 1998).

No trabalho de Fortes et al. (2007) são apresentados mapas de risco de rebaixamento de aquíferos na APA de Cafuringa, onde as regiões dos condomínios do Grande Colorado, a Vila Basevi e a porção inicial do Núcleo Rural do Lago Oeste são classificadas como áreas de alto e muito alto risco no rebaixamento de aquíferos no domínio fraturado, já na classificação de risco nos aquíferos no domínio poroso a Vila Basevi e regiões do Núcleo Rural do Lago Oeste apresentam risco alto e muito alto. 


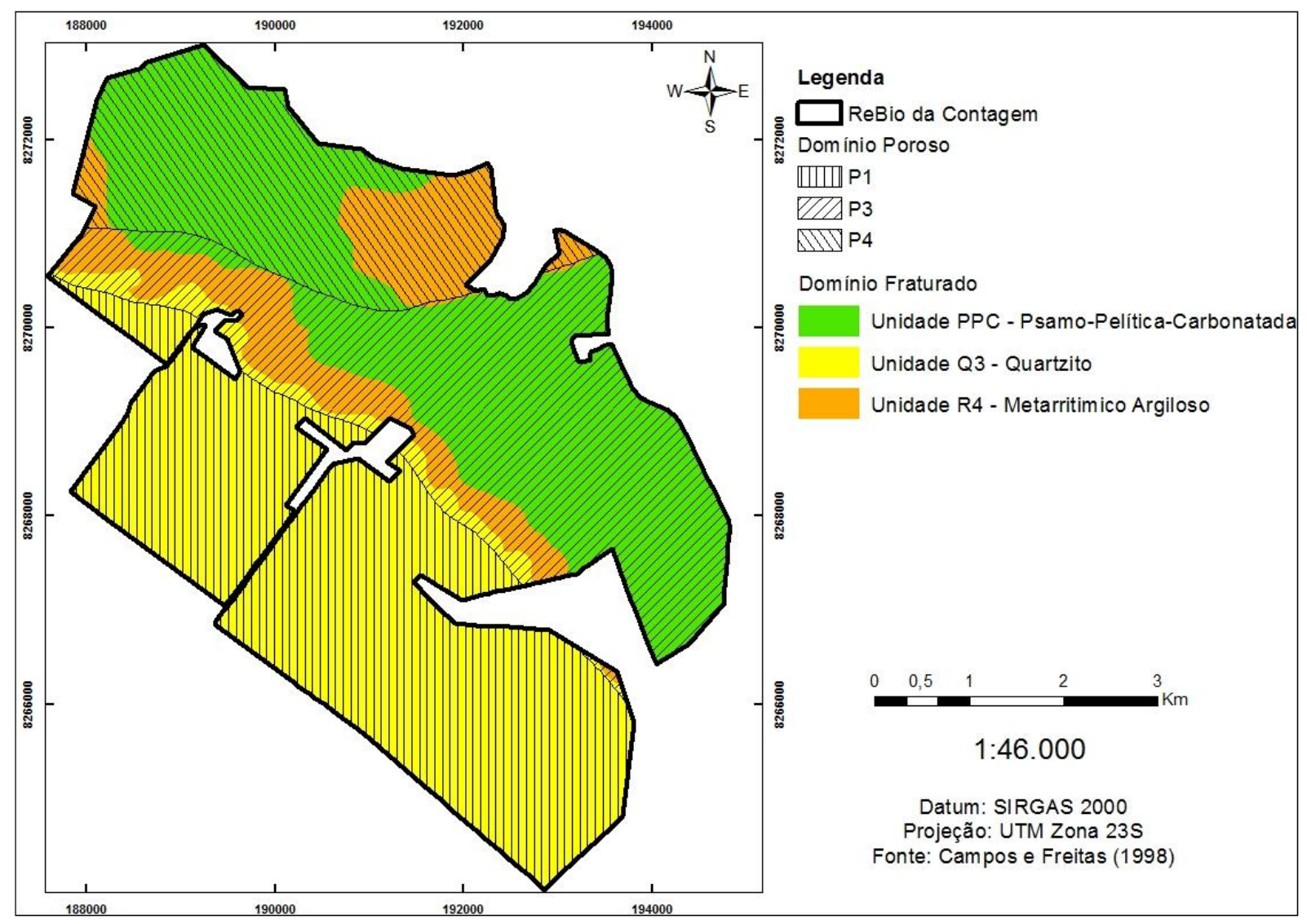

Figura 12. Mapa hidrogeológico da ReBio da Contagem. 


\section{METODOLOGIA}

\subsection{MATERIAIS}

Para a elaboração deste trabalho foram utilizados os softwares: ArcGis 10.1 nos processos de armazenamento, processamento, manipulação dos dados e informações geográficas e geração de mapas; Excel 2007 para auxílio nos processos de classificação de dados e geração de tabelas; e o software V-LATE (vector-based landscape analysis tools extension) versão 2.0 beta para ArcGis 10 .

O software V-LATE é uma extensão do ArcGis que trabalha com dados vetoriais executando cálculos baseados em conjuntos de dados poligonais, podendo ser utilizado na análise da estrutura da paisagem para configuração espacial de áreas (LANG e BLASCHKE, 2009). Este software apresenta boa aplicabilidade e resultados na análise de métricas da paisagem como nos trabalhos de Betancur (2015), Lima e Rocha (2011), Rudolpho et al. (2013), Lucas, Fonseca e Jesus (2013).

Os dados vetoriais utilizados neste trabalho e suas especificações constam abaixo na Tabela 3 e a escala de trabalho utilizada foi de 1:10.000.

Tabela 3. Dados vetoriais utilizados na elaboração do trabalho.

\begin{tabular}{l|c|c|c}
\multicolumn{1}{c|}{ Dado } & Datum & Fonte & Ano \\
$\begin{array}{l}\text { Unidades de Conservação } \\
\text { Federais }\end{array}$ & SIRGAS 2000 & ICMBIO & 2015 \\
\hline Mapa de uso do solo & SICAD & Terracap & 2010 \\
\hline Vegetação & SICAD & Terracap & 2010 \\
\hline Hidrografia & SICAD & Terracap & 2010 \\
\hline Geomorfologia & WGS 1984 & IBGE & 2013 \\
\hline MDT & SICAD & Terracap & 2010 \\
\hline APM & SICAD & Terracap & 2010 \\
\hline Pedologia & SAD 69 & Embrapa & - \\
\hline
\end{tabular}

Foram utilizadas ortofotos do ano de 2014, concedidas pela Companhia Imobiliária de Brasília (Terracap), com as seguintes configurações:

- Dado: mosaico

- Resolução espacial: 0,24m

- Datum: SIRGAS 2000

- Projeção: UTM 
- Número de Bandas: 3

Para registro fotográficos foi utilizada câmera digital, modelo Sony Cyber-shot DSC H70, 16.1 mega pixels. Para foi o registro de imagens aéreas utilizado drone, modelo Phantom 3 Advanced, 12.4 mega pixels.

De acordo com o Sistema Geodésico Brasileiro (SGB), que utiliza como sistema geodésico de referência oficial no Brasil o SIRGAS2000 (DALAZOANA, 2001), os dados deste trabalho foram reprojetados para: SIRGAS2000 UTM Zona 23 Sul.

\subsection{MÉTODOS}

Para identificação da área de estudo foi feita a extração do shape da ReBio da Contagem do mapa de Unidades de Conservação Federais, disponibilizado pelo ICMBIO. Através de um sistema de informações geográficas foi delimitado um raio de $3 \mathrm{~km}$ (buffer) em torno da unidade de conservação para análise dos efeitos de borda e para trabalhar com uma zona de amortecimento a fim de minimizar os impactos negativos sobre a unidade.

Neste trabalho optou-se pela demarcação de uma área ao redor da Reserva como objeto de estudo ao invés de trabalhar com a bacia de contribuição, pelo fato da mesma se encontrar localizada em um entroncamento de importante conectividade de três bacias, sendo de grande valor o detalhamento das cabeceiras de drenagem para a conservação do local. Outro motivo para a escolha se deve à Bacia do Paranoá não fazer parte da bacia de contribuição da ReBio da Contagem, porém esta abrange em seu território o PARNA Brasília que é uma área de extrema relevância para proporcionar conectividade de áreas e o estabelecimento de corredores ecológicos (Figuras 2 e 11).

A primeira etapa após a delimitação do buffer de $3 \mathrm{~km}$ na ReBio da Contagem foi a classificação do uso da região, para isto foram extraídas as classes de uso do solo e de vegetação provenientes dos respectivos mapas de classificação da Terracap, com algumas adaptações necessárias conforme as mudanças ocorridas no local de estudo, observadas através de interpretação da região por meio de ortofoto.

Para a modelagem dos procedimentos de análise foram desenvolvidas etapas conforme fluxograma (Figura 13). 


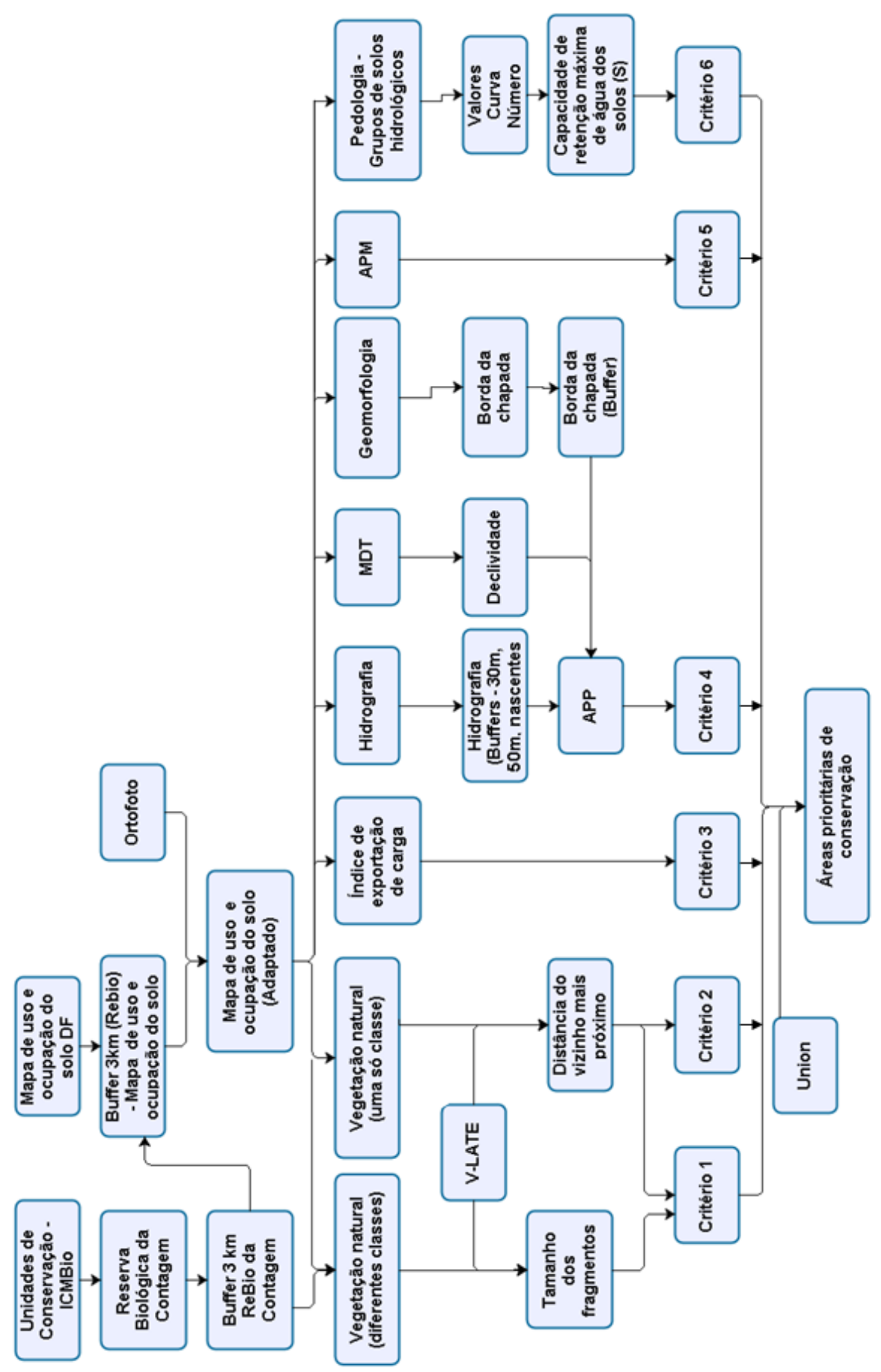

Figura 13. Fluxograma da modelagem de dados para definição das áreas prioritárias de proteção. 
Para propor estratégias de sustentabilidade, foi adotada a metodologia utilizada em Steinke, Queiroz e Saito (2008), que estabelece critérios para a classificação de áreas prioritárias de conservação. Cada critério possui uma ou mais categorias de análise, estas categorias são divididas em classes, de acordo com a nota recebida (varia de 0 a 10), referente à relevância de suas características para a conservação e sustentabilidade da área de estudo. Algumas notas são atribuídas de acordo com a ausência ou presença do objeto de análise em cada critério (nota 0 ou 10), outras são atribuídas de acordo com a distribuição e intervalos dos valores resultantes que compõem cada critério (nota de 0 a 10). Todos os critérios utilizados foram físicos, para melhor investigação da região sob a perspectiva do ambiente natural.

Para isto foi utilizada uma base de dados georreferenciados, que passaram por processos de modelagem espacial simples, baseada em planos de informação que foram aplicados em forma de mapas temáticos, estes foram sobrepostos e combinados de acordo com os 6 critérios, que serão descritos a seguir, gerando assim um mapa final de áreas prioritárias para a conservação. Para a elaboração do mapa final os critérios foram associados por meio do comando Union, no ArcGis, que permite a soma das notas da tabela de atributos.

Optou-se por utilizar notas ao invés de pesos para que nenhum dos critérios fosse valorizado em relação a outro, deste modo é possível contemplar o mapa final sobre duas diferentes abordagens, a da conservação de áreas mais preservadas e a da conservação de áreas com prioridade de gestão.

\section{Critério 1: Áreas que constituam mosaicos de fragmentos remanescentes da vegetação nativa, que possam constituir ou reforçar corredores ecológicos, para cada tipologia de fitofisionomia básica}

Este critério tem o objetivo de estabelecer conectividade entre os fragmentos de vegetação localizados dentro da área e também no buffer da Reserva, favorecendo a formação ou o reforço de corredores ecológicos, avaliando dessa maneira a importância dos mesmos. A hierarquização dos fragmentos foi feita baseada na classificação de duas categorias: tamanho dos fragmentos e proximidade entre fragmentos de mesma fitofisionomia.

Para obtenção do tamanho da área dos fragmentos e da distância do vizinho mais próximo foi utilizado o programa V-LATE, que trabalha com medidas da paisagem a fim de caracterizar o estado ecológico da paisagem. 
A categoria do tamanho do fragmento é muito utilizada para caracterizar a riqueza e abundância de espécies e a fragmentação da paisagem; e neste trabalho foi hierarquizada de acordo com os tamanhos das áreas dos fragmentos. Ela se baseia na porcentagem de áreas das classes individuais na paisagem. "A área total de uma classe é a soma de todas as áreas de manchas de uma determinada classe numa paisagem" (LANG e BLASCHKE, 2009, p. 256), e é calculada no V-LATE pela fórmula (MCGARIGAL e MARKS, 1995):

$$
C A=\sum_{j=1}^{n} a_{i j}\left(\frac{1}{10,000}\right)
$$

Onde:

CA: Área da classe (ha)

n: Número de fragmentos na paisagem de cada tipo de classe

$\mathrm{j}=1$ : Número de fragmentos

aij: Área $\left(\mathrm{m}^{2}\right)$ do fragmento ij

A outra categoria utilizada foi a proximidade entre fragmentos. A distância entre os fragmentos influencia a probabilidade das espécies se deslocarem e se espalharem (JESUS, 2013) e foi hierarquizada entre fragmentos de mesmo tipo fisionômico. Considerou-se para o presente trabalho as fitofisionomias baseadas na categorização da vegetação da Terracap, que têm representados os 3 tipos de formações do Cerrado, sendo a formação florestal representada principalmente pelas Matas de Galeria, a formação savânica principalmente pelo Cerrado típico e a formação campestre pelo Campo (limpo e sujo). A distância entre os fragmentos foi calculada para cada classe de vegetação.

A distância do vizinho mais próximo corresponde ao "mínimo da quantidade de distâncias de uma mancha de saída para todas as manchas de destino. Assim sendo, ela corresponde à distância à mancha mais próxima da mesma classe" (LANG e BLASCHKE, 2009, p. 291); onde é medida a distância euclidiana mais curta de uma mancha de saída para uma mancha de destino. Este cálculo é realizado por meio da equação (MCGARIGAL, 2015):

$E N N=h i j$

Onde:

ENN: distância do vizinho mais próximo 
hij: Distância (m) do fragmento ij para o fragmento vizinho mais próximo, do mesmo tipo (classe), com base na distância de borda a borda do fragmento.

A classificação final do critério 1 foi feita considerando a soma das notas das duas categorias.

Critério 2: Áreas que constituam mosaicos de fragmentos remanescentes de vegetação nativa, que possam constituir ou reforçar corredores ecológicos, integrando as diversas tipologias de fitofisionomia básica

Este critério se assemelha ao critério 1, porém este não depende do tipo fitofisionômico, o que importa é a formação ou reforço de corredores ecológicos, constituindo mosaicos integrados de todas fitofisionomias, através da conexão dos fragmentos de vegetação, que proporcionarão benefícios ambientais para a área de estudo.

A classificação foi feita baseada na proximidade entre fragmentos, que foi hierarquizada de acordo com a distância do vizinho mais próximo, entre fragmentos, independente do tipo fisionômico. A distância do vizinho mais próximo foi calculada através do programa V-LATE, para a vegetação como um todo, sem distinção de classes.

\section{Critério 3: Exportação de cargas poluidoras na região da ReBio da Contagem}

Neste critério foram analisadas as áreas que mais contribuem para a exportação de cargas poluidoras na área da ReBio da Contagem e ao seu redor no raio de $3 \mathrm{~km}$. Para isto, foi adotada a metodologia utilizada em Steinke et al. (2004), onde é calculada uma estimativa de geração de carga poluidora, baseada no modelo de correlação utilizado no Plano de Desenvolvimento e Proteção Ambiental da Bacia do Guarapiranga (SMA, 2003): Modelo de Correlação entre o Uso do Solo e a Qualidade da Água - MQUAL, utilizado pela Companhia Ambiental do Estado de São Paulo CETESB.

O modelo foi escolhido por ser um modelo com a função de explicitar as relações entre o uso, ocupação e manejo do solo na bacia, e a qualidade das águas para fins de abastecimento público, para melhor desempenho do sistema hídrico, analisando (SMA, 2010, p.98):

- da qualidade futura do manancial sob diversas hipóteses de ocupação da bacia, de implantação de sistemas de saneamento e ações de controle; 
- de novas políticas de uso do solo, com a identificação clara das contribuições específicas de cada categoria de uso do solo na qualidade da água, além de áreas prioritárias para preservação e recuperação;

- do licenciamento de grandes empreendimentos, com o uso de uma ferramenta adequada para avaliação de impactos sobre a qualidade das águas;

- de novas medidas de controle ambiental que possam ser propostas, a partir do conhecimento mais detalhado da bacia.

Este modelo é constituído de três módulos inter-relacionados: geração de cargas, simulação dos principais tributários e simulação do Reservatório, cada um deles representando os fenômenos de geração e autodepuração das cargas poluidoras nos três ambientes considerados: as superfícies do terreno, onde estão as fontes de cargas poluidoras; os rios principais e seus afluentes; e por fim o Reservatório. Para o trabalho utilizou-se apenas o parâmetro para geração de cargas, no qual basicamente as estimativas estão associadas ao uso e ocupação da terra.

Assim como em Steinke et al. (2004) as cargas poluidoras foram estimadas com base no coeficiente de exportação de cada parâmetro de qualidade da água. As estimativas são associadas ao tipo de cobertura do solo. Para este critério foram dispensados da análise os fragmentos referentes aos corpos d'água da área de estudo.

Foram realizadas simplificações que resultaram na equação básica a seguir:

$\mathrm{Ci}=\Sigma($ Ai x ci)

Onde:

$\mathrm{Ci}$ = carga média de cada parâmetro de qualidade de água ( $\mathrm{Kg} / \mathrm{dia})$;

$\mathrm{Ai}=$ área ocupada pelas diferentes categorias de cobertura do solo $\left(\mathrm{Km}^{2}\right)$;

ci $=$ coeficientes de exportação de cargas difusas de cada parâmetro ambiental para as diferentes categorias de cobertura do solo $\left(\mathrm{Kg} / \mathrm{Km}^{2} \mathrm{dia}\right)$;

As cargas poluidoras foram calculadas em termos de médias anuais e estimadas para cada parâmetro em $\mathrm{Kg} /$ dia conforme Tabela 4: 
Tabela 4. Valores referência para exportação de cargas de acordo com o tipo de Cobertura do Solo.

\begin{tabular}{|c|c|c|c|c|}
\hline Fonte & Unidade & $\begin{array}{c}\text { Fósforo } \\
\text { total }\end{array}$ & $\begin{array}{c}\text { Nitrogênio } \\
\text { total }\end{array}$ & $\begin{array}{c}\text { Sólidos } \\
\text { suspensos }\end{array}$ \\
\hline Atividade Agrícola & $\mathrm{kg} / \mathrm{km}^{2}$.dia & 0,346 & 2,950 & 230 \\
\hline Reflorestamento & $\mathrm{kg} / \mathrm{km}^{2}$.dia & 0,039 & 0,600 & 20 \\
\hline Mata / Capoeirão & $\mathrm{kg} / \mathrm{km}^{2}$.dia & 0,039 & 0,600 & 20 \\
\hline Capoeira / Campo & $\mathrm{kg} / \mathrm{km}^{2}$.dia & 0,028 & 0,500 & 30 \\
\hline Chácaras & $\mathrm{kg} / \mathrm{km}^{2}$.dia & 0,050 & 0,900 & 40 \\
\hline $\begin{array}{c}\text { Áreas Urbanas - Padrão } \\
\text { Superior }\end{array}$ & $\mathrm{kg} / \mathrm{km}^{2}$.dia & 0,034 & 1,274 & 50 \\
\hline $\begin{array}{c}\text { Áreas Urbanas - Padrão } \\
\text { Inferior }\end{array}$ & $\mathrm{kg} / \mathrm{km}^{2}$.dia & 0,135 & 2,548 & 100 \\
\hline $\begin{array}{c}\text { Áreas de Uso Industrial e } \\
\text { Comercial }\end{array}$ & $\mathrm{kg} / \mathrm{km}^{2}$.dia & 0,081 & 1,784 & 70 \\
\hline
\end{tabular}

Fonte: SMA (2003) com adaptações.

\section{Critério 4: Áreas de Preservação Permanente e suas adjacências}

As áreas de preservação permanentes - APP foram demarcadas conforme Lei 12651/12 que dispõe sobre:

- a largura mínima das faixas marginais dos cursos d'água natural, perene e intermitente, sendo:

- 30 metros a distância para cursos d'água com até 10 metros de largura;

- 50 metros de distância para os cursos d'água de 10 até 50 metros de largura;

- 100 metros de distância para os cursos d'água que tenham de 50 até 200 metros de largura

- a distância em torno de nascentes de no mínimo 50 metros;

- a distância em torno de lagos e lagoas naturais a largura mínima é de 100 metros em zonas rurais, exceto para corpos d'água com até 20 hectares de superfície, cuja faixa marginal será de 50 metros.

- as encostas ou partes destas com declividade superior a $45^{\circ}$ (graus);

- as bordas dos tabuleiros ou chapadas, até a linha de ruptura do relevo, em faixa nunca inferior a 100 (cem) metros em projeções horizontais.

A delimitação das áreas de APPs foi feita no ArcGis através de uma interpretação visual por meio de ortofoto, juntamente com a rede de drenagens e com a classe de corpos d'água e foram extraídas informações da largura dos cursos d'água e o tamanho da área dos corpos 
d'água da área de estudo, em seguida foram criados buffers ao redor das drenagens, corpo d'água e nascentes.

As nascentes foram estabelecidas no trabalho de acordo com os inícios de cursos d'água do mapa hidrográfico da Terracap, de escala 1:10.000, que apresenta tanto cursos d'água perenes como intermitentes. A Lei 12.651 define nascente como "afloramento natural do lençol freático que apresenta perenidade e dá início a um curso d'água" (BRASIL, 2012. Art.3º Par.XVII), e embora esta seja a mesma lei que estabelece os atuais padrões das APPs, neste trabalho foi utilizado o conceito de nascente da Resolução 303 do Conama "local onde aflora naturalmente, mesmo que de forma intermitente, a água subterrânea" (CONAMA, 2012. Art. $2^{\underline{o}}$ Par.II), pelo fato de também considerar os cursos d'água intermitentes, ampliando desta maneira as regiões de proteção de afloramento de água e por ser o conceito mais conservacionista.

Para as encostas foi utilizado o mapa de declividade do terreno (Figura 9) obtido a partir de um MDT (Modelo Digital de Terreno) da Terracap, onde foram marcadas como APPs os trechos que apresentaram declividade acima de $45^{\circ}$.

Para as bordas de chapada foi utilizado o shape de geomorfologia do IBGE onde a feição da borda de chapada foi extraída e ajustada manualmente de acordo com o mapa de declividade (Figura 9), e em seguida foi delimitado um buffer correspondente ao limite de 100 metros. Ao contrário das demais representações de APPs deste trabalho, em que os buffers são estabelecidos ao redor dos polígonos, circundando-os, neste caso o buffer foi marcado da borda do polígono para o seu interior, pois essa é a área que necessita ser abrangida por uma APP por conta de sua susceptibilidade.

\section{Critério 5: Áreas de Proteção de Mananciais}

As Áreas de Proteção de Mananciais (APM's) tem como objetivos a conservação, recuperação e manejo fontes das bacias hidrográficas que abastecem os pontos de captação de água da Companhia de Água e Esgotos de Brasília - CAESB (CAESB, 2015).

Como a proteção dos recursos hídricos envolve a qualidade de vários outros recursos e a conservação do meio natural, esta tarefa de proteção acaba se relacionando com práticas de educação ambiental, planos de manejo das bacias, recuperação de áreas degradadas dentro dos 
polígonos das áreas de contribuições das captações, além de instruir quanto às atividades de uso e ocupação do solo no seu interior (CAESB, 2015).

A ReBio da Contagem apresenta duas captações de água localizadas no Ribeirão Contagem e Córrego Paranoazinho. No presente trabalho foram demarcadas as áreas que pertencem ou não às APM's, por meio das áreas demarcadas como APM's de dados Terracap, como fator de ações prioritárias para conservação.

\section{Critério 6: Capacidade de retenção máxima de água dos solos}

Este critério identifica a capacidade de retenção máxima de água dos solos (S), na região da Reserva e no buffer de $3 \mathrm{~km}$ ao redor, sendo possível observar quais as áreas que apresentam maior susceptibilidade à percolação de água e, assim, maior contribuição para a recarga de aquíferos.

Para o cálculo de $\mathrm{S}$ foram utilizados valores do método de Curva Número $(\mathrm{CN})$ e do mapa de Grupo de solos Hidrológicos, obtidos dos trabalhos de Castro (2013), Menezes (2010) e Gonçalves et al. (2009), que apresentam estes valores referentes ao bioma Cerrado e região do DF.

O método da Curva-Número $(C N)$ foi desenvolvido pelo Serviço de Conservação de Solos (SCS), do Departamento de Agricultura dos Estados Unidos (USDA). Ele determina a quantidade de chuva que infiltra no solo ou no aquífero e a quantidade de chuva que escoa superficialmente numa determinada região em função do grupo de solos hidrológicos e do uso e ocupação do solo, (ZHAN \& HUANG, 2004). Os valores de CN estão relacionados com a capacidade de retenção máxima dos solos $(\mathrm{S})$ e os utilizados neste trabalho são apresentados na Tabela 5:

Tabela 5. Valores de CN adaptados de Lima (2009), Menezes (2010) e Castro (2013).

\begin{tabular}{l|c|c|c|c}
\hline \multirow{2}{*}{\multicolumn{1}{c|}{ Classe de uso do solo }} & \multicolumn{4}{|c}{ Grupo de solos } \\
\cline { 2 - 5 } & A & B & C & D \\
\hline Mata de Galeria & 20 & 40 & 49 & 52 \\
\hline Cerrado & 39 & 61 & 74 & 80 \\
\hline Campo & 49 & 69 & 79 & 84 \\
\hline Reflorestamento & 25 & 36 & 52 & 64 \\
\hline
\end{tabular}




\begin{tabular}{lllll}
\hline Cultura agrícola & 63 & 74 & 81 & 85 \\
\hline Solo Exposto & 59 & 74 & 82 & 86 \\
\hline Área urbana de baixa densidade & 64 & 75 & 83 & 87 \\
\hline Área urbana de média densidade & 68 & 79 & 86 & 89 \\
\hline Grama & 59 & 67 & 74 & 81 \\
\hline Estrada pavimentada & 72 & 82 & 87 & 89 \\
\hline Pastagem & 49 & 69 & 79 & 84 \\
\hline
\end{tabular}

O grupo de solos hidrológicos do DF são classificados em quatro grupos (SARTORI, 2004; GONÇALVES, 2009; CASTRO, 2013), e se diferenciam quanto à: transmissão da água pela camada de solo com a menor condutividade hidráulica saturada e a profundidade de qualquer camada; taxa de transmissão de água; textura; quantidade de matéria orgânica; estrutura e grau de inchamento quando saturados.

De acordo com classificação dos solos da SCS, os grupos se dividem em (SARTORI, 2004):

Grupo A: Os solos deste grupo apresentam baixo potencial de escoamento e alta taxa de infiltração uniforme quando estão completamente molhados. Representados principalmente por areias ou cascalhos profundos e excessivamente drenados. Apresentam elevada taxa de transmissão de água (taxa mínima de infiltração: > 7,62 mm/h).

Grupo B: Os solos deste grupo apresentam moderada taxa de infiltração quando completamente molhados. Representados principalmente por solos moderadamente profundos a profundos, razoável a bem drenados, com textura meio fina a levemente grossa. Apresentam moderada taxa de transmissão de água (taxa mínima de infiltração: 3,81-7,62 mm/h).

Grupo C: Os solos deste grupo têm baixa taxa de infiltração quando completamente molhados, dificuldade de movimento da água das camadas superiores para as inferiores e textura moderadamente fina. Apresentam baixa taxa de transmissão de água (taxa mínima de infiltração: 1,27-3,81 mm/h).

Grupo D: Os solos deste grupo apresentam alto potencial de escoamento e taxa de infiltração muito baixa quando completamente molhados, principalmente os solos argilosos com alto potencial de expansão. Representados por solos com uma grande permanência do lençol freático, solos com argila dura ou camadas de argila próxima da superfície e solos expansivos agindo como materiais impermeabilizantes próximos da superfície. Apresentam uma taxa muito baixa de transmissão de água (taxa mínima de infiltração: $0-1,27 \mathrm{~mm} / \mathrm{h}$ ). 
As áreas prioritárias de conservação são as que apresentam valores mais elevados de capacidade de retenção máxima de água dos solos (S), que foi calculado conforme equação abaixo (para precipitação em $\mathrm{mm}$ ):

$$
\mathrm{S}=(25400 / \mathrm{CN})-254
$$

Com a finalidade de esclarecer dúvidas sobre a ReBio da Contagem, saber as principais problemáticas e conflitos existentes na região, mediante informações obtidas diretamente do órgão ambiental responsável pela gestão da UC e observar o ponto de vista do mesmo, foi realizada uma entrevista ao servidor do ICMBio, Enrique Mieza Balbuena, que faz parte da equipe responsável pela Reserva e que respondeu algumas perguntas sobre a região (APÊNDICE A).

Foram registradas imagens da Reserva da Contagem, obtidas através de visitação à área de estudo. O acesso ao local foi autorizado pelo ICMBio, por meio do Sistema de Autorização e Informação em Biodiversidade (SISBIO), com autorização de n 54651-1. Foram registradas imagens fotográficas e filmagens aéreas, com prioridade para as regiões de conflito e impactos ambientais que ocorrem dentro da UC. 


\section{RESULTADOS E DISCUSSÃO}

Foi analisada uma área de mais de 14.000 ha, a qual inclui a Reserva Biológica da Contagem (3.426 ha) e mais um raio de $3 \mathrm{~km}$ ao seu redor. Deste total cerca de $68 \%$ correspondem a áreas de vegetação natural, 0,13\% são recursos hídricos, incluindo os de origem antrópica e cerca de $31 \%$ áreas de uso antrópico (Tabela 6) e (Figura 14).

Tabela 6. Dados das áreas naturais, antrópicas e de recursos hídricos da região da ReBio da Contagem.

\begin{tabular}{cccc}
\hline $\begin{array}{c}\text { Região da ReBio da Contagem } \\
\text { e buffer 3km }\end{array}$ & $\mathbf{N}^{\circ}$ de fragmentos & Hectares & $\%$ \\
\hline Área natural & 632 & $9.689,49$ & $68,28 \%$ \\
Área antropizada & 2.309 & $4.482,53$ & $31,59 \%$ \\
Recursos hídricos & 41 & 18,01 & $0,13 \%$ \\
\hline Total & $\mathbf{2 . 9 8 2}$ & $\mathbf{1 4 . 1 9 0 , 0 2}$ & $\mathbf{1 0 0 , 0 0 \%}$ \\
\hline
\end{tabular}




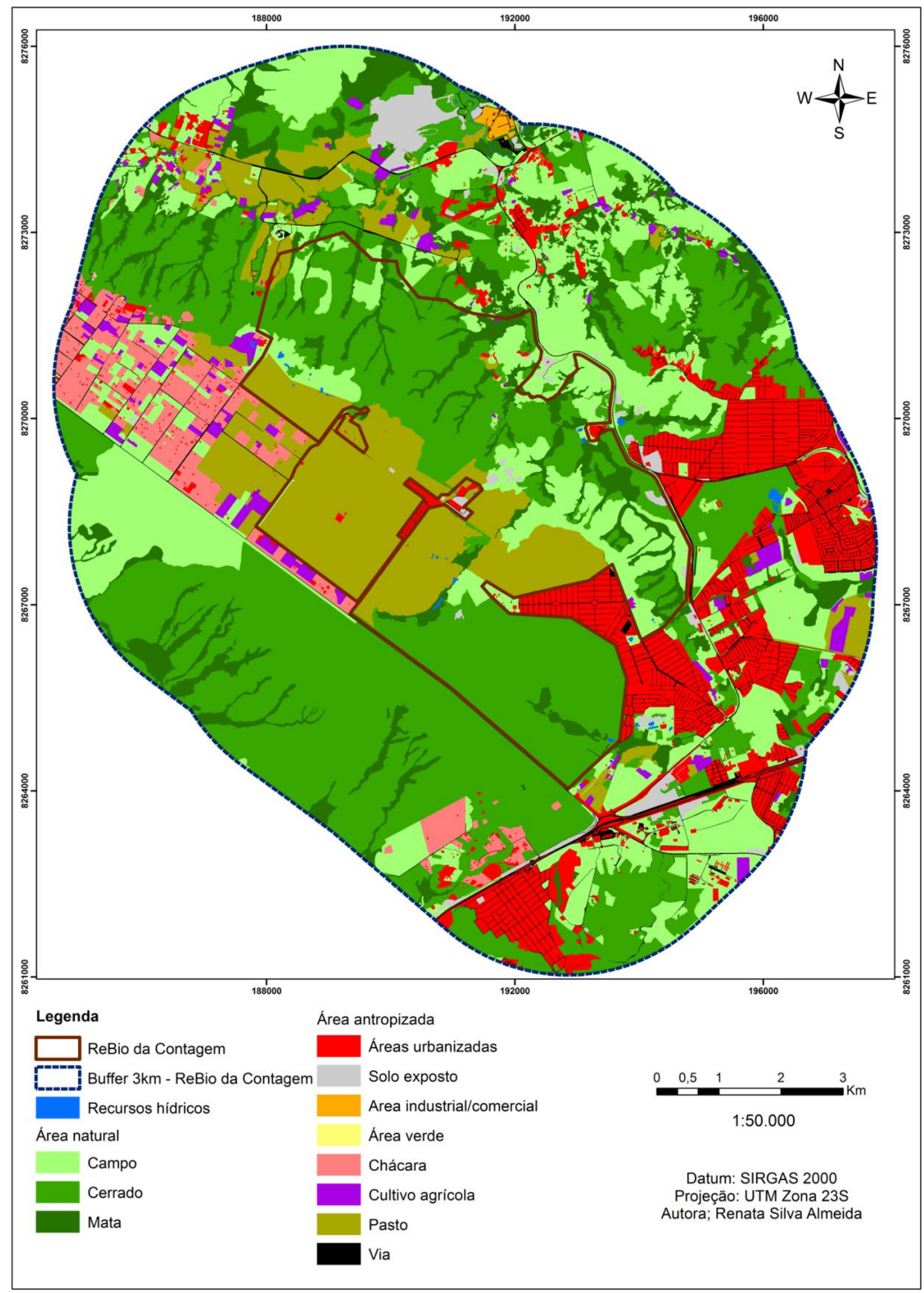

Figura 14. Mapa de caracterização de áreas naturais, antrópicas e de recursos hídricos da região da ReBio da Contagem.

Fonte dos dados: Terracap 2010; ICMBio 2015. 
Foram produzidos mapas exclusivos para cada critério de análise, de modo que cada um foi verificado de maneira independente em relação aos demais. Não foram utilizadas nos resultados destes mapas de identificação de áreas prioritárias, as áreas correspondentes aos fragmentos de recursos hídricos. Sem desmerecer o alto grau de importância destes para a conservação da biodiversidade e, embora os recursos hídricos tenham sido utilizados como critérios de prioridade, suas áreas não foram inclusas pelo fato das análises corresponderem à parte de uso do solo, isto geraria divergência nos resultados finais e na prioridade de conservação para estes fragmentos.

Critério 1: Áreas que constituam mosaicos de fragmentos remanescentes da vegetação nativa, que possam constituir ou reforçar corredores ecológicos, para cada tipologia de fitofisionomia básica.

Para o critério 1 foram geradas duas tabelas, referentes às categorias de análise. A primeira categoria relativa à classificação dos fragmentos de acordo com o tamanho de sua área, foi dividida e recebeu notas para cada classe conforme Tabela 7.

\begin{tabular}{c}
$\begin{array}{c}\text { Tabela 7. Categoria de avaliação: } \\
\text { Quanto à área do fragmento (ha) }\end{array}$ \\
\hline Classe
\end{tabular}

De acordo com a Tabela 8 é possível observar que, embora apresentem uma das menores quantidades de fragmentos (14), os fragmentos com maiores tamanhos de áreas representam a maior porcentagem na região de estudo: 58,13\%, o que significa um bom resultado, tendo em vista a importância de grandes áreas na manutenção das espécies de fauna e flora.

A presença de grandes áreas compactas favorece a conservação de espécies por apresentar um efeito de borda menos atuante, isso contribui para a sobrevivência de espécies, desde a atingir a idade adulta como também na sua reprodução, com maiores áreas para se propagarem e menos efeitos externos as afetando. 
Por outro lado, os fragmentos representados em maiores quantidades (202 e 177), são também os que correspondem às menores porcentagens da área abordada, isto pode significar um alto impacto relacionado ao efeito de borda, principalmente nestes fragmentos de até 1 ha que são atingidos por completo em relação a este efeito (HERRMANN et al., 2005), mas diante de uma análise geral da área, ele se torna pouco influente não chegando nem a $6 \%$ do total (Tabela 8).

Tabela 8. Classificação de acordo com os tamanhos das áreas dos fragmentos em hectares.

\begin{tabular}{ccccc}
\hline Categoria & Nota & $\mathbf{N}^{\circ}$ de fragmentos & Total (ha) por categoria & $\%$ \\
\hline acima de 100 ha & 10 & 14 & $5.632,72$ & $58,13 \%$ \\
\hline de 50 a 100 ha & 8 & 14 & 978,30 & $10,10 \%$ \\
\hline de 10 a 50 ha & 6 & 98 & $2.072,40$ & $21,39 \%$ \\
\hline de 5 a 10 ha & 4 & 65 & 460,88 & $4,76 \%$ \\
\hline de 1 a 5 ha & 2 & 202 & 484,87 & $5,00 \%$ \\
\hline até 1 ha & 1 & 177 & 60,33 & $0,62 \%$ \\
\hline & Total & $\mathbf{5 7 0}$ & $\mathbf{9 . 6 8 9 , 5 0}$ & $\mathbf{1 0 0 \%}$ \\
\hline
\end{tabular}

A segunda categoria de análise do critério 1 corresponde à distância do vizinho mais próximo, entre fragmentos de mesmo tipo fitosionômico. Os resultados foram divididos nas classes com distâncias do vizinho ais próximo, conforme Tabela 9.

Tabela 9. Categoria de avaliação:

Distância do vizinho mais próximo (para cada tipologia de fitofisionomia)

\begin{tabular}{cc}
\hline Categoria & Nota \\
\hline até $1 \mathrm{~m}$ & 10 \\
\hline de 1 a $10 \mathrm{~m}$ & 8 \\
\hline de 10 a $50 \mathrm{~m}$ & 6 \\
\hline de 50 a $100 \mathrm{~m}$ & 4 \\
\hline de 100 a $500 \mathrm{~m}$ & 2 \\
\hline acima de $500 \mathrm{~m}$ & 1 \\
\hline
\end{tabular}

Os resultados obtidos mostraram uma boa conectividade entre os fragmentos, com as maiores porcentagens de áreas conectadas em até $1 \mathrm{~m}$ de distância $(33,38 \%)$ e de 1 a $10 \mathrm{~m}$ $(38,17 \%)$. A particularidade relacionada ao tipo fitofisionômico (campo, cerrado, mata) torna o resultado obtido ainda melhor, pois demonstra que os remanescentes de vegetação nativa encontram-se em sua maior parte próximos, o que facilita a movimentação de espécies e troca genética, principalmente de espécies mais sensíveis a distúrbios ambientais e que habitam fitofisionomias específicas. 
A classe de maior distância entre os fragmentos foi também a que teve o menor número de fragmentos (7) e o menor tamanho total (120,85 ha), um bom resultado no sentido de conservação de espécies por terem influência mínima no total analisado $(1,25 \%)$ (Tabela 10).

Tabela 10. Classificação de acordo com a distância (m) do vizinho mais próximo, para cada tipologia de fitofisionomia.

\begin{tabular}{ccccc} 
Categoria & Nota & $\mathbf{N}^{\circ}$ de fragmentos & Total (ha) por categoria & $\%$ \\
\hline até $1 \mathrm{~m}$ & 10 & 24 & $3.234,28$ & $33,38 \%$ \\
\hline de 1 a $10 \mathrm{~m}$ & 8 & 203 & $3.698,75$ & $38,17 \%$ \\
\hline de 10 a $50 \mathrm{~m}$ & 6 & 184 & $1.567,18$ & $16,17 \%$ \\
\hline de 50 a $100 \mathrm{~m}$ & 4 & 60 & 287,95 & $2,97 \%$ \\
\hline de 100 a $500 \mathrm{~m}$ & 2 & 92 & 780,48 & $8,05 \%$ \\
\hline acima de $500 \mathrm{~m}$ & 1 & 7 & 120,85 & $1,25 \%$ \\
\hline & Total & $\mathbf{5 7 0}$ & $\mathbf{9 . 6 8 9 , 4 9}$ & $\mathbf{1 0 0 \%}$ \\
\hline
\end{tabular}

O resultado do critério 1 ficou dividido em áreas de baixíssima, baixa, média, alta e altíssima prioridade, conforme Tabela 11. Sendo a classe mais abundante $(53,51 \%)$ correspondente à categoria de Altíssima prioridade.

O resultado obtido é muito bom, pois as áreas mais importantes para conservação representam mais de $74 \%$ do total, isto demonstra grandes áreas de vegetação com alto grau de conexão e forte relação fitofisionômica, o que contribui para a possibilidade de se estabelecer ou reforçar corredores ecológicos na região e favorecendo a biodiversidade do local.

Tabela 11. Somatório das notas obtidas nas categorias: área dos fragmentos e distância do vizinho mais próximo, para cada tipologia de fitofisionomia.

\begin{tabular}{ccccc}
\hline \multicolumn{5}{c}{ Critério 1 } \\
\hline Categoria & Nota & $\mathbf{N}^{\circ}$ de fragmentos & Total (ha) por categoria & $\%$ \\
\hline Baixíssima prioridade & $1-4$ & 63 & 113,84 & $1,17 \%$ \\
\hline Baixa prioridade & $5-8$ & 209 & 688,99 & $7,11 \%$ \\
\hline Média prioridade & $9-12$ & 229 & $1.688,99$ & $17,43 \%$ \\
\hline Alta prioridade & $13-16$ & 58 & $2.012,95$ & $20,77 \%$ \\
\hline Altíssima prioridade & $17-20$ & 11 & $5.184,72$ & $53,51 \%$ \\
\hline & Total & $\mathbf{5 7 0}$ & $\mathbf{9 . 6 8 9 , 4 9}$ & $\mathbf{1 0 0 \%}$ \\
\hline
\end{tabular}

No mapa do critério 1 é possível observar a representação de cada categoria de prioridade separada de acordo com os tipos de fitofisionomia (Figura 15). 


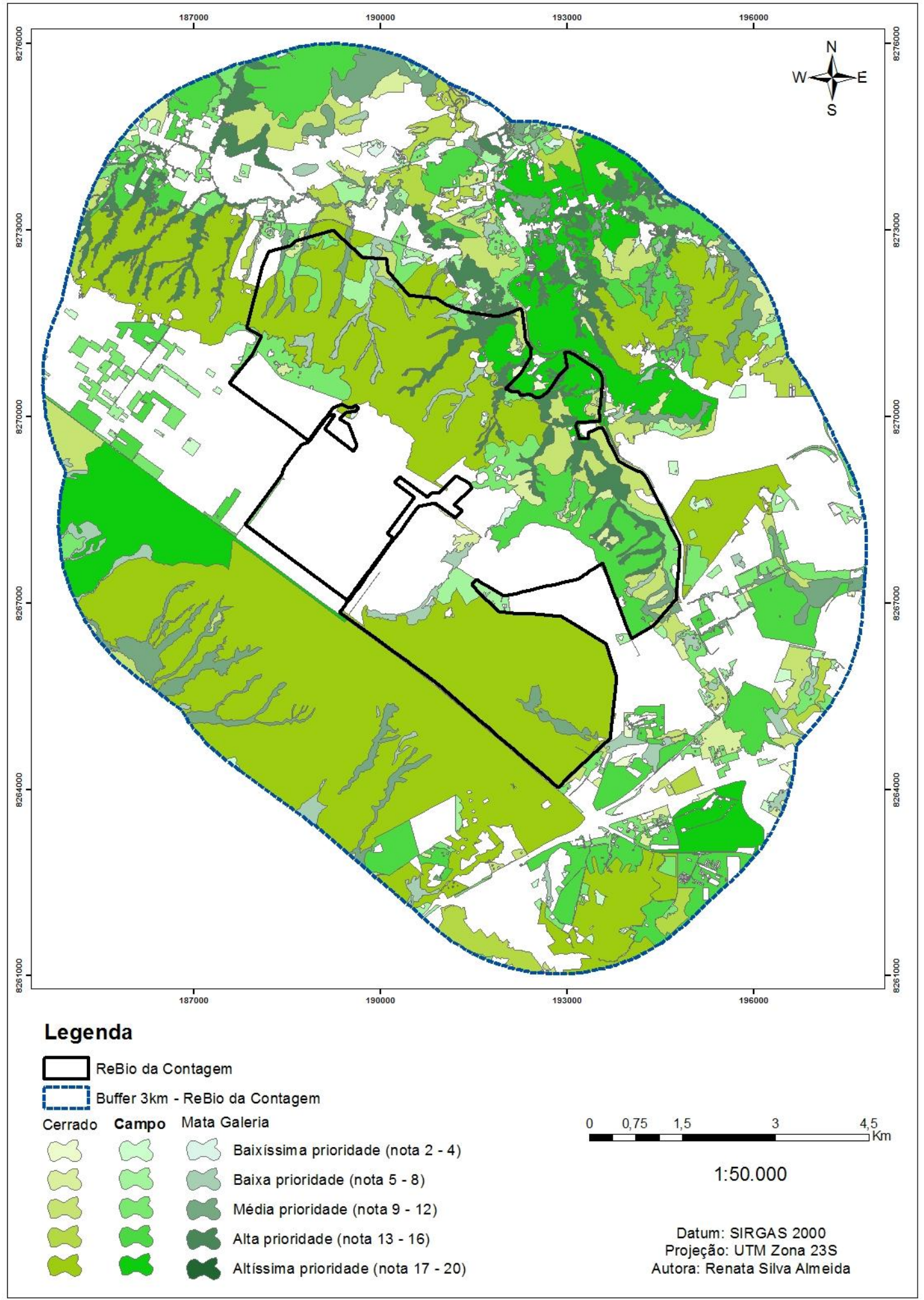

Figura 15. Mapeamento do critério 1: Áreas que constituam mosaicos de fragmentos remanescentes da vegetação nativa, que possam constituir ou reforçar corredores ecológicos, para cada tipologia de fitofisionomia básica (cerrado, campo e mata de galeria).

Fonte dos dados: Terracap 2010; ICMBio 2015. 
Critério 2: Áreas que constituam mosaicos de fragmentos remanescentes da vegetação nativa, que possam constituir ou reforçar corredores ecológicos, integrando as diversas tipologias de fitofisionomia básica.

$\mathrm{Na}$ análise do critério 2 os resultados referentes à distância do vizinho mais próximo, foram calculados entre fragmentos de vegetação de modo geral, independente do tipo fitosionômico. Os resultados foram divididos em classes (Tabela 12).

Tabela 12. Categoria de avaliação:

Distância do vizinho mais próximo (integrando as diversas tipologias de fitofisionomias)

\begin{tabular}{cc}
\hline Classe & Nota \\
\hline até $1 \mathrm{~m}$ & 10 \\
\hline de 1 a $10 \mathrm{~m}$ & 8 \\
\hline de 10 a $50 \mathrm{~m}$ & 6 \\
\hline de 50 a $100 \mathrm{~m}$ & 4 \\
\hline de 100 a $500 \mathrm{~m}$ & 2 \\
\hline acima de $500 \mathrm{~m}$ & 1 \\
\hline
\end{tabular}

Os resultados obtidos mostraram excelente conectividade entre os fragmentos, com 97,28\% de áreas conectadas em até $1 \mathrm{~m}$ de distância, ou seja, quase todos os fragmentos de vegetação natural encontram-se interligados ou bastante próximos uns dos outros. Não houve nenhum fragmento que apresentasse distância do vizinho mais próximo com mais de $500 \mathrm{~m}$ e a porcentagem de fragmentos com mais de $10 \mathrm{~m}$ de distância é muito baixa, não chegando nem a $1 \%$ do total (Tabela 13 ).

Tabela 13. Classificação de acordo com a distância (ha) do vizinho mais próximo, integrando as diversas tipologias de fitofisionomia.

\begin{tabular}{ccccc} 
Classe & Nota & $\mathbf{N}^{\circ}$ de fragmentos & Total (ha) por categoria & $\%$ \\
\hline até $1 \mathrm{~m}$ & 10 & 451 & $9.426,32$ & $97,28 \%$ \\
\hline de 1 a $10 \mathrm{~m}$ & 8 & 74 & 180,55 & $1,86 \%$ \\
\hline de 10 a $50 \mathrm{~m}$ & 6 & 28 & 48,19 & $0,50 \%$ \\
\hline de 50 a $100 \mathrm{~m}$ & 4 & 7 & 9,78 & $0,10 \%$ \\
\hline de 100 a $500 \mathrm{~m}$ & 2 & 10 & 24,65 & $0,25 \%$ \\
\hline acima de $500 \mathrm{~m}$ & 1 & 0 & 0,00 & $0,00 \%$ \\
\hline & Total & $\mathbf{5 7 0}$ & $\mathbf{9 . 6 8 9 , 4 9}$ & $\mathbf{1 0 0 , 0 0 \%}$ \\
\hline
\end{tabular}

O resultado do critério 2 ficou dividido em áreas de baixíssima, baixa, média, alta e altíssima prioridade, conforme Tabela 14. Sendo a classe mais abundante $(97,28 \%)$ 
correspondente à categoria de Altíssima prioridade. As categorias de baixíssima, baixa e média prioridade, se somadas não chegam a $1 \%$ da área total avaliada.

Este é um excelente resultado em termos de potencial ecológico para o estabelecimento de corredores de biodiversidade e para evitar a insularização da UC. Algumas espécies como, por exemplo, o Tatu-canastra (Priodontes maximus) e o Tamanduá-bandeira (Myrmecophaga tridactyla), que são ameaçadas de extinção e protegidas pela ReBio da Contagem (ICMBIO, 2015), precisam de grandes áreas para se locomoverem. Ambos apresentam uma área de vida de cerca de 1.000 ha, sendo que a do Tamanduá-bandeira pode chegar até 1.900 ha (SILVEIRA et al., 2009; MACHADO, DRUMMOND e PAGLIA, 2010), isto demanda grandes extensões de vegetação natural conectadas.

Tabela 14. Classificação de prioridade de acordo com a distância do vizinho mais próximo, integrando as diversas tipologias de fitofisionomias.

\begin{tabular}{ccccc}
\hline \multicolumn{7}{c}{ Critério 2 } & & \\
\hline Categoria & Nota & $\mathbf{N}^{\circ}$ de fragmentos & Total (ha) por categoria & $\%$ \\
\hline Baixíssima prioridade & $1-2$ & 10 & $\mathbf{2 4 , 6 5}$ & $0,25 \%$ \\
\hline Baixa prioridade & $3-4$ & 7 & 9,78 & $0,10 \%$ \\
\hline Média prioridade & $5-6$ & 28 & 48,19 & $0,50 \%$ \\
\hline Alta prioridade & $7-8$ & 74 & 180,55 & $1,86 \%$ \\
\hline Altíssima prioridade & $9-10$ & 451 & $9.426,32$ & $97,28 \%$ \\
\hline & Total & $\mathbf{5 7 0}$ & $\mathbf{9 . 6 8 9 , 4 9}$ & $\mathbf{1 0 0 , 0 0 \%}$ \\
\hline
\end{tabular}

No mapa do critério 2 é possível observar a representação de cada categoria de prioridade integrando os diversos tipos fitofisionômicos (Figura 16). 


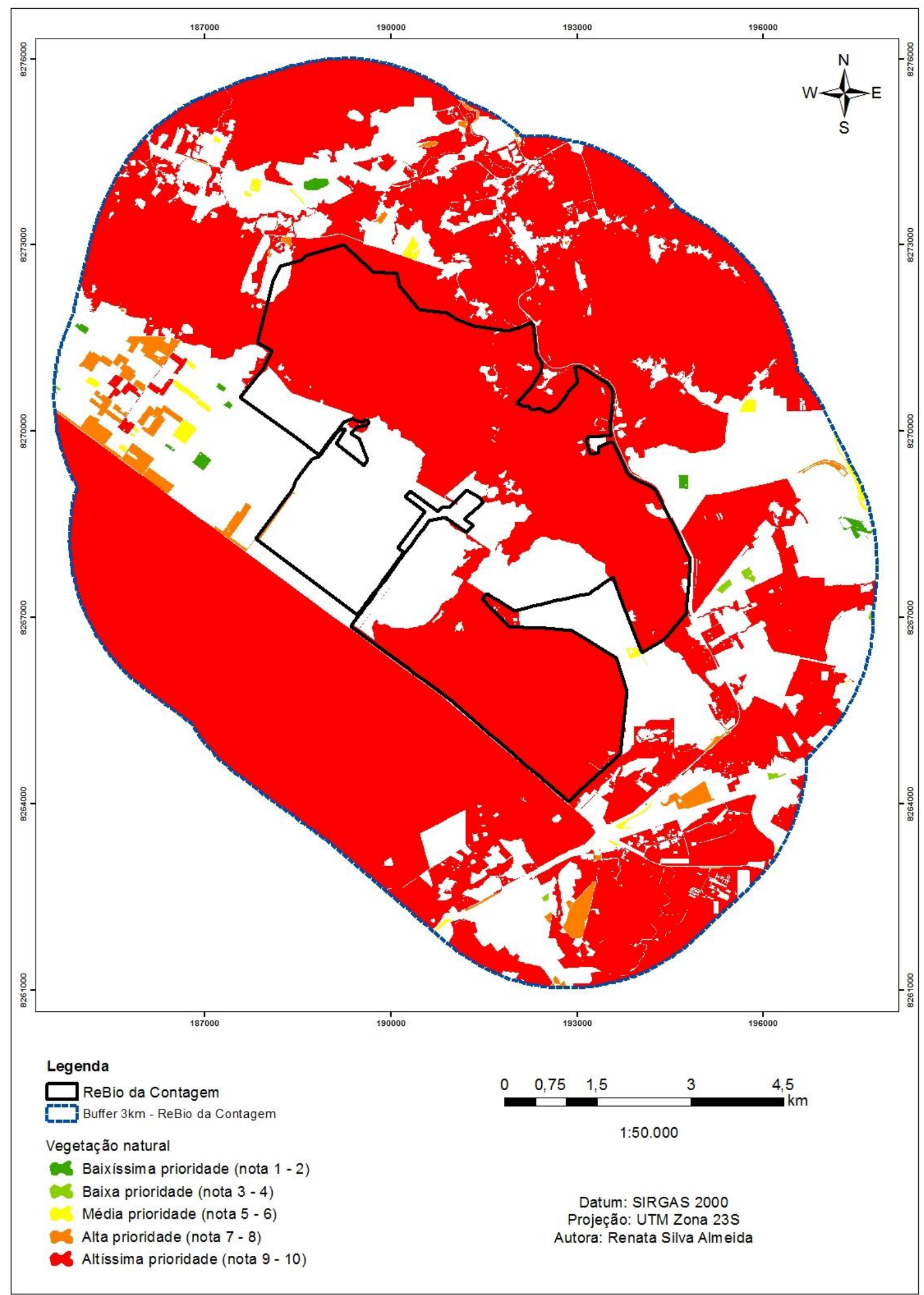

Figura 16. Mapeamento do critério 2: Áreas que constituam mosaicos de fragmentos remanescentes da vegetação nativa, que possam constituir ou reforçar corredores ecológicos, , integrando as diversas tipologias de fitofisionomias básicas (mata de galeria, campo e cerrado).

Fonte dos dados: Terracap 2010; ICMBio 2015. 


\section{Critério 3: Áreas com maior exportação de cargas poluidoras na região da ReBio}

\section{da Contagem.}

Este critério apresentou resultados baseados na estimativa de exportação de cargas poluidoras (Tabela 4), analisando de acordo com o uso do solo a quantidade de exportação que em média é gerada. Os resultados foram divididos em classes de baixíssima, baixa, média, alta e altíssima prioridade, conforme valores de exportação que variaram em menores de $100 \mathrm{~kg} / \mathrm{km}^{2} / \mathrm{ano}$, até acima de $10.000 \mathrm{~kg} / \mathrm{km}^{2} /$ ano (Tabela 15 ).

Tabela 15. Classificação da estimativa de exportação $\left(\mathrm{kg} / \mathrm{km}^{2} / \mathrm{ano}\right)$, baseada no somatório das cargas de fósforo, nitrogênio e sólidos em suspensão de cada fragmento.

\begin{tabular}{cccccc}
\hline \multicolumn{7}{c}{ Critério 3 } \\
\hline Classe & Nota & $\mathbf{N}^{\circ}$ de fragmentos & Hectares & $\%$ \\
\hline Baixíssima prioridade $<100 \mathrm{~kg} / \mathrm{km}^{2} /$ ano & 2 & 1.457 & 201,14 & $1,42 \%$ \\
\hline Baixa prioridade $100-999 \mathrm{~kg} / \mathrm{km}^{2} /$ ano & 4 & 1.151 & $2.111,28$ & $14,90 \%$ \\
\hline Média prioridade $1.000-4.999 \mathrm{~kg} / \mathrm{km}^{2} /$ ano & 6 & 270 & $3.126,43$ & $22,06 \%$ \\
\hline Alta prioridade $5.000-9.999 \mathrm{~kg} / \mathrm{km}^{2} /$ ano & 8 & 39 & $1.656,70$ & $11,69 \%$ \\
\hline Altíssima prioridade $>10.000 \mathrm{~kg} / \mathrm{km}^{2} /$ ano & 10 & 24 & $7.076,47$ & $49,93 \%$ \\
\hline & Total & $\mathbf{2 . 9 4 1}$ & $\mathbf{1 4 . 1 7 2 , 0 2}$ & $\mathbf{1 0 0 , 0 0 \%}$ \\
\hline
\end{tabular}

A Tabela 15 traz os resultados da estimativa de exportação de cada fragmento, porém como o tamanho de cada fragmento apresenta bastante interferência no resultado, a visualização das áreas no mapa de exportação de cargas foi normalizada pelo tamanho da área, sendo representado de acordo com a Figura 17.

Através do mapa de exportação de cargas é possível observar que os índices de exportação mais elevados aparecem nas áreas urbanizadas, áreas de cultura e industriais (Figura 14). Levando-se em consideração a grande proximidade dessas áreas com os cursos d'água presentes na região, isso reforça a necessidade de maiores cuidados para a proteção dos mananciais de água.

Porém, como a Reserva da Contagem encontra-se na parte mais elevada da chapada, ela não recebe exportação de cargas externas, os recursos hídricos tem sua cabeceira na Reserva, havendo por conta disso pouca pressão sobre a mesma do ponto de vista de fluxo de água superficial. Para compreender isso melhor é necessário observar o mapa de topografia, declividade e cursos d'água da região (Figuras 8, 9 e 11).

Embora conte com a topografia do relevo a seu favor e não receba cargas superficiais diretas e demais poluentes da maioria da vizinhança, a presença da Vila Basevi, que se 
encontra localizada bem ao centro da ReBio da Contagem e ao topo de várias nascentes, além das demais residências presentes na área da Reserva, contribuem com índices elevados de exportação de cargas e ainda apresentam uma problemática maior pelo fato de não apresentar rede de saneamento básico, isto prejudica diretamente o solo da região por meio de contaminação direta pelo escoamento de poluentes (Figura 3). Considerando-se que parte das cargas poluidoras passem por processos de infiltração no solo, a recarga dos aquíferos e cursos d'água da região também podem ser prejudicados. Ademais, essas cargas são exportadas para fora da chapada, alimentando outras bacias e influenciando a qualidade de recursos hídricos que vão além dos limites territoriais da Reserva. 


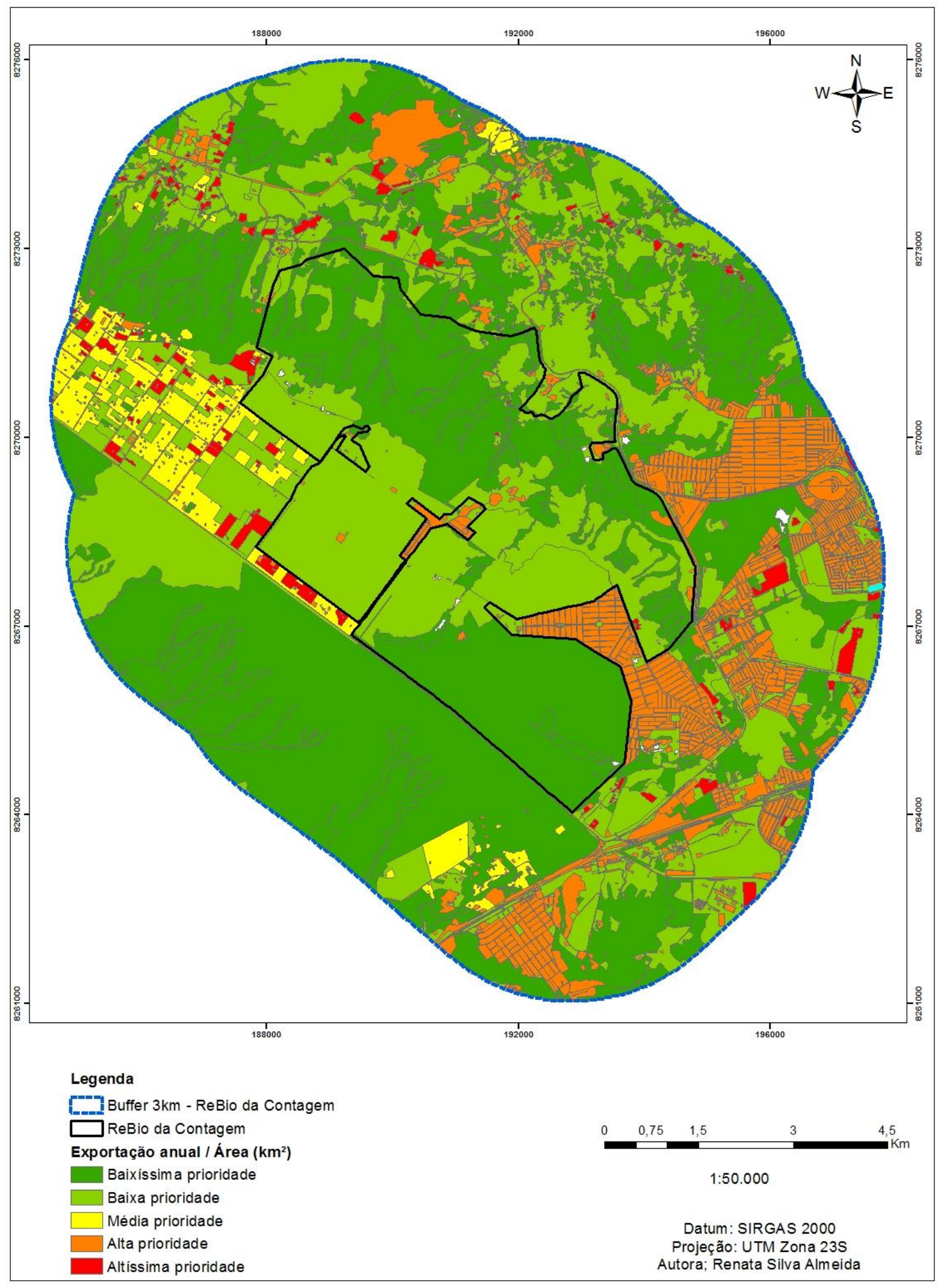

Figura 17. Mapeamento do critério 3: Áreas com maior exportação de cargas poluidoras ( somatório das cargas de nitrogênio, fósforo e sólidos em suspensão).

Fonte dos dados: Terracap 2010; ICMBio 2015. 


\section{Critério 4: Áreas de Preservação Permanente e suas adjacências.}

A região da Reserva não apresenta cursos d'água de grandes larguras, chegando nos trechos mais largos a uma distância de $10 \mathrm{~m}$ entre as margens, estabelecendo-se assim uma APP de 30 m para todas as drenagens. Somente dois corpos d'água apresentaram área maior que 1 ha, sendo um deles um tanque artificial, que não foi considerado para análise, o outro corpo d'água apresentou uma área de 4,40 ha e foi delimitada uma APP de $50 \mathrm{~m}$ ao seu redor.

Também foram demarcadas APPs de $50 \mathrm{~m}$ ao redor de todas as nascentes, na região de borda de chapada foram demarcadas APPs de $100 \mathrm{~m}$ e os trechos com declividade superior a $45^{\circ}$ (graus) foram definidos como áreas de APP.

Ao total foi demarcada uma área de 1.849,42 ha de APP de $30 \mathrm{~m}$ em cursos d'água, sendo que deste total 130,57 ha, o equivalente a $7 \%$, se encontram em áreas de uso antrópico. Um total de 7,37 ha foi demarcado como APP de $50 \mathrm{~m}$ ao redor do corpo d'água e deste valor somente 0,13 ha $(2 \%)$ corresponde a áreas de uso antrópico. Ao redor das nascentes foi gerada uma área de APP $50 \mathrm{~m}$ de 375,05 ha, sendo que 9\% (32,30 ha) deste total são representados por áreas antrópicas, já a área de APP de borda de chapada corresponde a 359,69 ha, e desses $15 \%\left(55,55\right.$ ha) são áreas de uso antrópico. As APPs de declividade maior que $45^{\circ}$ apresentaram uma área total de 19,13 ha, sendo praticamente toda ela representada por áreas de uso natural 99\% (18,90 ha) (Tabela 16).

Tabela 16. Especificação dos diferentes tipos de APPs na ReBio da Contagem e a proporção de áreas naturais e antropizadas nos mesmos.

\begin{tabular}{|c|c|c|c|c|c|}
\cline { 2 - 6 } \multicolumn{1}{c|}{} & \multicolumn{2}{c|}{ Uso natural } & \multicolumn{2}{c|}{ Uso antrópico } & \multicolumn{1}{c|}{} \\
\hline APPs & Hectares & $\%$ & Hectares & $\%$ & Total (ha) \\
\hline APP 30m (cursos d'água) & $1.718,86$ & $93 \%$ & 130,57 & $7 \%$ & $\mathbf{1 . 8 4 9 , 4 2}$ \\
\hline APP 50m (corpos d'água) & 7,24 & $98 \%$ & 0,13 & $2 \%$ & $\mathbf{7 , 3 7}$ \\
\hline APP 50m (nascentes) & 342,74 & $91 \%$ & 32,30 & $9 \%$ & $\mathbf{3 7 5 , 0 5}$ \\
\hline APP 100m (borda da chapada) & 304,14 & $85 \%$ & 55,55 & $15 \%$ & $\mathbf{3 5 9 , 6 9}$ \\
\hline APP declividade maior que 45 & 18,90 & $99 \%$ & 0,23 & $1 \%$ & $\mathbf{1 9 , 1 3}$ \\
\hline
\end{tabular}

O resultado do critério 4 foi dividido em áreas com a presença de APP, que receberam nota 10 e áreas sem a presença de APP, que receberam nota 0 . Dentro da área de estudo e em seu entorno de raio de $3 \mathrm{~km}$, correspondentes a áreas antropizadas e naturais (14.172,01 ha), apenas $16 \%$ são áreas de APPs (Tabela 17). 
Tabela 17. Classificação das áreas com e sem a presença de APP na ReBio da Contagem.

\begin{tabular}{|c|c|r|c|}
\hline \multicolumn{4}{|c|}{ Critério 4} \\
\hline APP & Nota & Hectares & $\%$ \\
\hline Áreas com APPs & 10 & $2.337,24$ & $16 \%$ \\
\hline Áreas sem APPs & 0 & $11.834,77$ & $84 \%$ \\
\hline & Total: & $14.172,01$ & $100 \%$ \\
\cline { 2 - 5 }
\end{tabular}

O valor correspondente ao total de hectares das áreas com a presença de APPs não é equivalente ao somatório dos valores de hectares de cada tipo de APP descriminado (o somatório delas seria de 2.610,66 ha), isso se deve ao fato de que algumas delimitações das APPs se sobrepõem a outras, por isso foram informadas as áreas representadas por cada tipo de APP e também o tamanho da área geral que é ocupada, independente do tipo de APP que abranja.

O uso e ocupação do solo impactam seriamente a rede de drenagem, pois quando a vegetação próxima à nascente e cursos d'água é suprimida, afeta a água que é percolada no solo e na recarga de aquíferos freáticos, alterando o comportamento do fluxo da água e também o desaparecimento de nascentes (PEREIRA et al., 2011).

Por isso é de suma importância a preservação dessas áreas para possibilitar o adensamento de fragmentos de remanescentes de vegetação nativa e consequentemente proteger os recursos hídricos da região, especialmente por se tratar de uma região de grande quantidade de nascentes e valor ecológico. Além da importância de conservação de áreas com grandes inclinações para evitar a erosão local.

No mapa do critério 4 é possível observar a representação das áreas de preservação permanente das regiões de nascentes, corpo d'água e cursos d'água da ReBio da Contagem e arredores (Figura 18). 


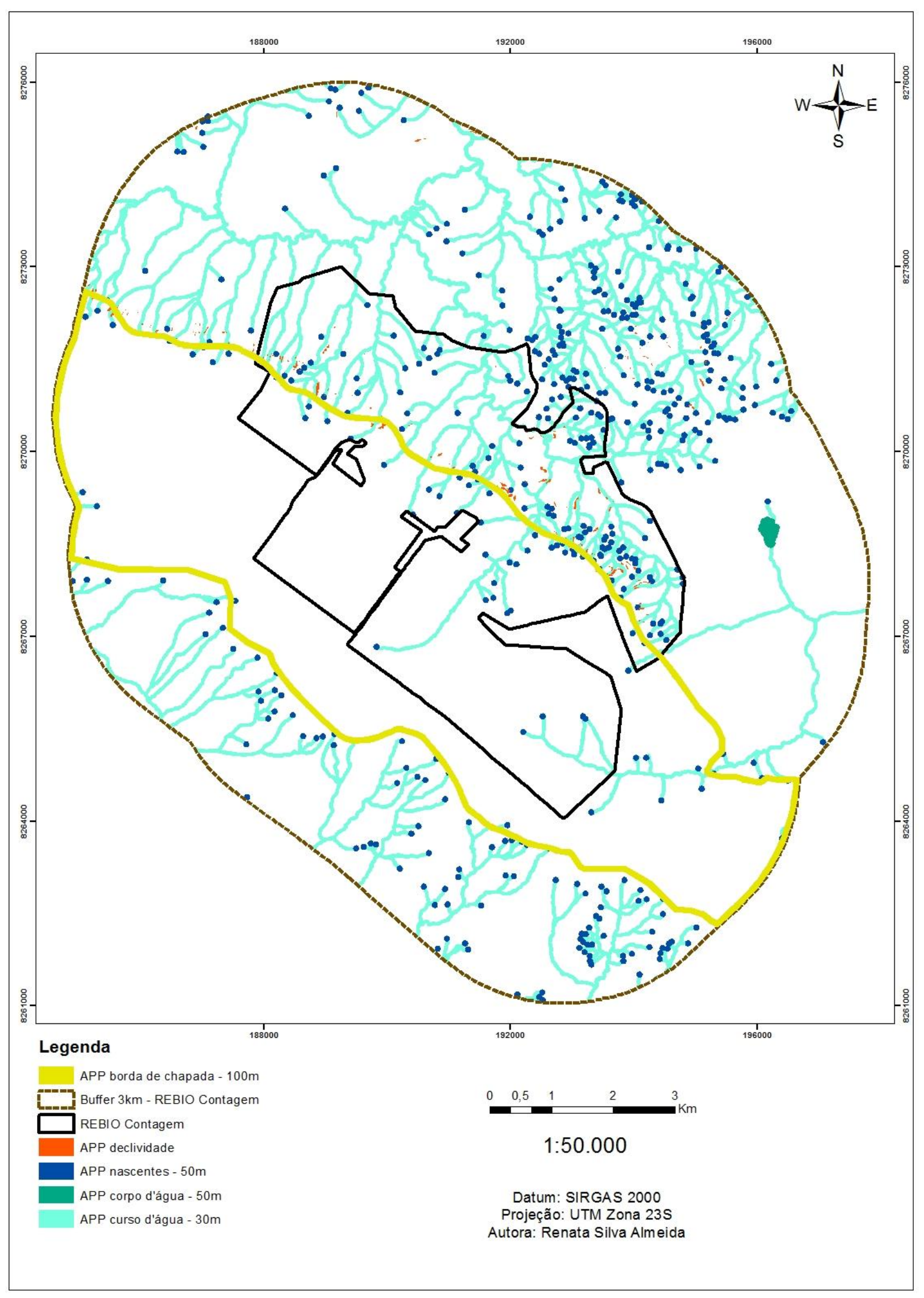

Figura 18. Mapeamento do critério 4: Áreas de Preservação Permanente - APPs e suas adjacências. Fonte dos dados: Terracap 2010; ICMBio 2015; IBGE 2013. 


\section{Critério 5: Áreas de Proteção de Mananciais}

O resultado do critério 5 foi dividido em áreas com a presença de APM, que receberam nota 10 e áreas sem a presença de APM, que receberam nota 0 . De toda a área da ReBio da Contagem e mais o seu buffer, correspondentes a áreas antropizadas e naturais (14.172,02 ha), 12\% (1.649,23 ha) pertencem à APMs, sendo que um pouco mais da metade dessa área (51\%) são áreas de uso antrópico (Tabelas 18 e 19).

Tabela 18. Classificação de acordo com a presença e ausência de APMs na ReBio da Contagem e a proporção de áreas naturais e antropizadas nas mesmas.

\begin{tabular}{c|c|c|c|c|r}
\cline { 2 - 5 } & \multicolumn{2}{|c|}{ Uso natural } & \multicolumn{2}{c|}{ Uso antrópico } & \multicolumn{1}{c}{} \\
\hline APM & Hectares & $\%$ & Hectares & $\%$ & Total (ha) \\
\hline com APM & 801,42 & $49 \%$ & 845,65 & $51 \%$ & $\mathbf{1 . 6 4 7 , 0 7}$ \\
sem APM & $8.892,75$ & $71 \%$ & $3.632,20$ & $29 \%$ & $\mathbf{1 2 . 5 2 4 , 9 5}$ \\
\hline
\end{tabular}

Tabela 19. Classificação das áreas pertencentes ou não às APMs na ReBio da Contagem.

\begin{tabular}{ccccc}
\hline \multicolumn{5}{c}{ Critério 5 } \\
\hline APM & Nota & $\mathbf{N}^{\circ}$ de áreas & Hectares & $\%$ \\
\hline Pertence & 10 & 316 & $1.647,07$ & $12 \%$ \\
\hline Não Pertence & 0 & 2.710 & $12.524,95$ & $88 \%$ \\
\hline & Total & $\mathbf{3 . 0 2 6}$ & $\mathbf{1 4 . 1 7 2 , 0 2}$ & $\mathbf{1 0 0 \%}$ \\
\hline
\end{tabular}

As áreas de proteção de mananciais são áreas importantes para garantir a qualidade de água para abastecimento, mais do que isso, para a proteção dos próprios recursos hídricos que dependem de vários fatores ambientais para apresentarem qualidade. Na região da ReBio da Contagem boa parte de área designada como APM encontra-se dentro da Unidade de Conservação e coberta por área de vegetação natural, porém a parte à Oeste representa uma área que vem passando por expansão de ocupação ao longo dos anos, principalmente de chácaras e regiões de cultivo (FORTES et al., 2003) (Figura 19).

Estas áreas de cultivo encontram-se entre umas das principais responsáveis por exportação de cargas poluidoras, que podem afetar as várias nascentes presentes pela região. O incentivo de medidas uso adequado do solo e protetivas para com os recursos hídricos, contribuem inclusive com os próprios pontos de captação de água, no sentido de gerar menos custos operacionais para as mesmas (STEINKE, QUEIROZ e SAITO, 2008). 


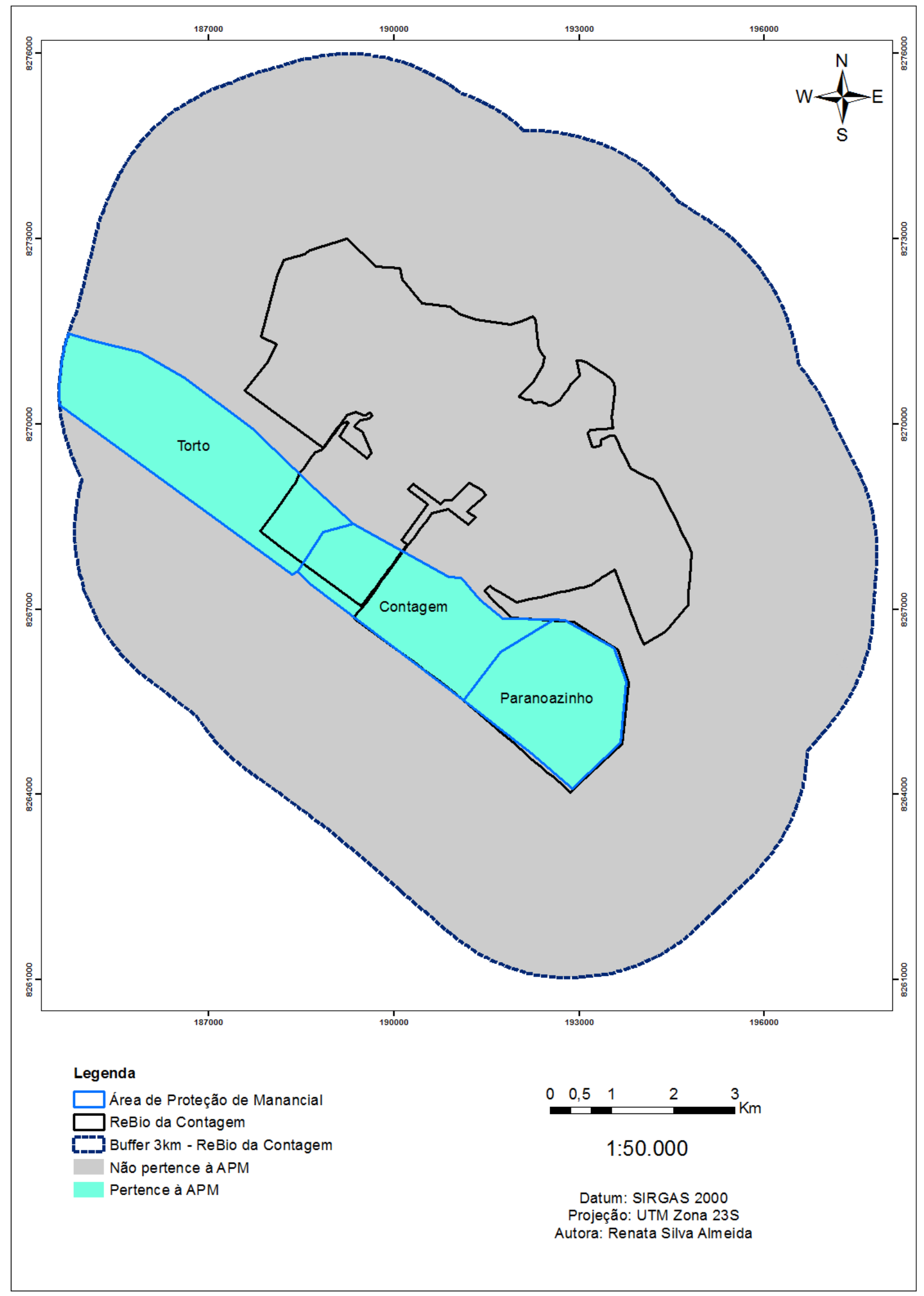

Figura 19. Mapeamento do critério 5: Áreas de Proteção de Mananciais na ReBio da Contagem.

Fonte dos dados: Terracap 2010; ICMBio 2015. 


\section{Critério 6: Capacidade de retenção máxima de água dos solos}

Os resultados de capacidade de retenção máxima de água dos solos foram divididos em 5 classes, onde os maiores valores correspondem às áreas com maior favorabilidade à infiltração de água e abastecimento dos aquíferos.

Observa-se na Tabela 20 que ocorre uma inversão dos valores relacionados às áreas com maiores valores para S. A maioria das áreas de uso natural (mais de 8.000 ha) encontram-se entre as classes de baixíssima e baixa prioridades de conservação, o que do ponto de vista de recarga hídrica é um resultado ruim, porém observando a Figura 20, os polígonos que apresentam Mata de Galeria se enquadram em prioridades mais altas de conservação, sendo este tipo fitofisionômico mais importante para a recarga dos recursos hídricos.

A maior parte das áreas de uso antrópico aparecem em locais de média e altíssima prioridade de conservação, sendo este um resultado extremamente preocupante, tendo em vista o crescimento urbano na região e o aumento de áreas impermeabilizadas, e por se tratar de locais com maior susceptibilidade de recarga de aquíferos, estes são locais mais sensíveis à intervenções. Embora estas áreas antrópicas incluídas na classe de altíssima prioridade se refiram em sua maioria a áreas verdes urbanas, não se pode excluir o nível de risco de que maiores pressões antrópicas possam atingir esses locais, colocando aumentando a vulnerabilidade de nascentes e drenagens na região.

Tabela 20. Critério 6 mostrando a capacidade de retenção máxima de água dos solos da ReBio da Contagem e em seu entorno.

\begin{tabular}{l|c|c|c|c|c|c}
\cline { 3 - 6 } \multicolumn{1}{c|}{ Classe } & Nso natural & \multicolumn{2}{c|}{ Uso antrópico } & \multicolumn{1}{c}{ Total } \\
\hline Baixíssima prioridade (valores S de 0,01 a 55,00) & 2 & $1.644,28$ & $73,67 \%$ & 587,81 & $26,33 \%$ & $\mathbf{2 . 2 3 2 , 0 9}$ \\
Baixa prioridade (valores S de 55,01 a 100,00) & 4 & $6.643,80$ & $94,86 \%$ & 360,22 & $5,14 \%$ & $\mathbf{7 . 0 0 4 , 0 2}$ \\
Média prioridade (valores S de 100,01 a 180,00) & 6 & 0,00 & $0,00 \%$ & $1.476,17$ & $100,00 \%$ & $\mathbf{1 . 4 7 6 , 1 7}$ \\
Alta prioridade (valores S de 180,01 a 350,00) & 8 & $1.265,92$ & $96,65 \%$ & 43,83 & $3,35 \%$ & $\mathbf{1 . 3 0 9 , 7 5}$ \\
Altíssima prioridade (valores S de 350,00 a 1.016,00) & 10 & 135,49 & $6,30 \%$ & $2.014,08$ & $93,70 \%$ & $\mathbf{2 . 1 4 9 , 5 7}$ \\
\hline & Total & $\mathbf{9 . 6 8 9 , 4 9}$ & $\mathbf{6 8 , 3 7 \%}$ & $\mathbf{4 . 4 8 2 , 1 1}$ & $\mathbf{3 1 , 6 3 \%}$ & $\mathbf{1 4 . 1 7 1 , 6 1}$ \\
\hline
\end{tabular}




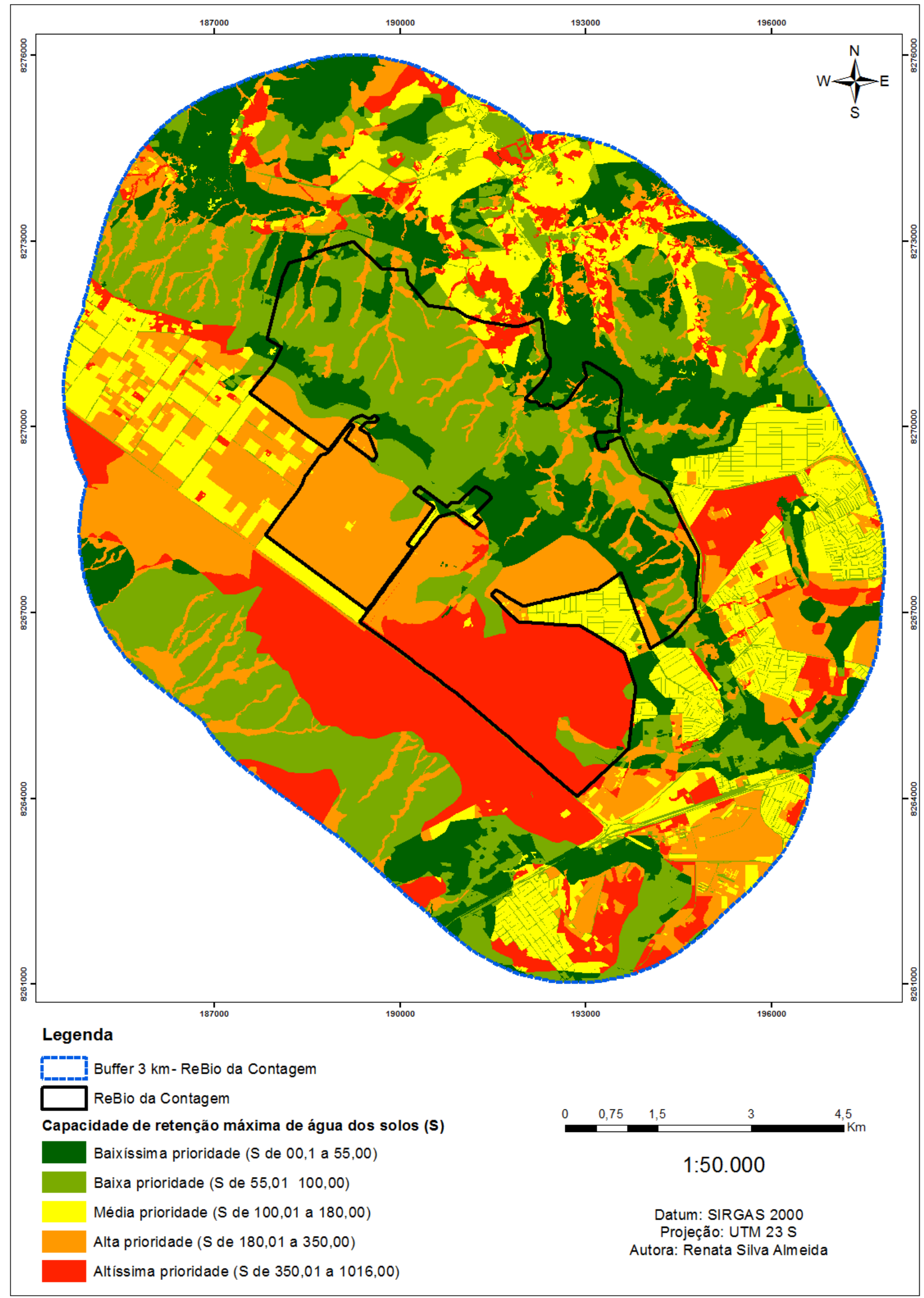

Figura 20. Mapeamento do critério 6: capacidade de retenção máxima de água dos solos.

Fonte dos dados: Terracap 2010; ICMBio 2015. 


\section{1 ÁREAS PRIORITÁRIAS DE CONSERVAÇÃO}

Os mapas gerados em cada um dos critérios acima foram sobrepostos e as áreas prioritárias de cada um deles tiveram suas notas somadas, gerando um mapa final que foi exposto sob duas diferentes abordagens: a de áreas prioritárias de conservação dos locais mais preservados e a dos locais mais deteriorados do ponto de vista ambiental.

$\mathrm{Na}$ abordagem da conservação dos locais mais preservados, as áreas que apresentaram baixíssima prioridade de conservação correspondem a $20,10 \%$ do total, onde praticamente todos os fragmentos contidos nesta classe são classificados como de uso antrópico $(99,92 \%)$. As áreas com baixa prioridade de conservação correspondem a 11,44\% do total, com maior parte dos fragmentos também discriminada como área de uso antrópico $(81,71 \%)$.

A partir da classificação de média prioridade de conservação os resultados mudam radicalmente, tanto para áreas de uso antrópico como para as de uso natural. Na classe de prioridade média, quase $90 \%$ das áreas se concentram no uso natural. Nas classes de prioridade de conservação alta e altíssima, que correspondem, respectivamente, a 37,76\% e 10,31\% do total, todas as suas áreas são de uso natural (Tabela 21).

Tabela 21. Classificação final de prioridade de conservação das áreas da ReBio da Contagem sob perspectiva da preservação.

\begin{tabular}{|c|c|c|c|c|c|c|c|}
\hline & \multirow{2}{*}{\multicolumn{2}{|c|}{ Uso natural }} & \multirow{2}{*}{\multicolumn{2}{|c|}{ Uso antrópico }} & \multirow[b]{3}{*}{ Total (ha) } & \multirow[b]{3}{*}{$\%$} \\
\hline & & & & & & & \\
\hline Prioridade de conservação & Nota & Hectares & $\%$ & Hectares & $\%$ & & \\
\hline Baixíssima & $2-14$ & 2,15 & $0,08 \%$ & $2.846,36$ & $99,92 \%$ & $2.848,51$ & $20,10 \%$ \\
\hline Baixa & $15-26$ & 296,40 & $18,29 \%$ & $1.324,28$ & $81,71 \%$ & $1.620,68$ & $11,44 \%$ \\
\hline Média & $27-38$ & $2.579,92$ & $89,25 \%$ & 310,87 & $10,75 \%$ & $2.890,79$ & $20,40 \%$ \\
\hline Alta & $39-50$ & $5.351,72$ & $100,00 \%$ & 0,00 & $0,00 \%$ & $5.351,72$ & $37,76 \%$ \\
\hline Altíssima & $51-68$ & $1.460,44$ & $100,00 \%$ & 0,00 & $0,00 \%$ & $1.460,44$ & $10,31 \%$ \\
\hline
\end{tabular}

Na Figura 21 é possível observar o mapa final das áreas prioritárias de conservação da Reserva Biológica da Contagem e sua zona de amortecimento. 


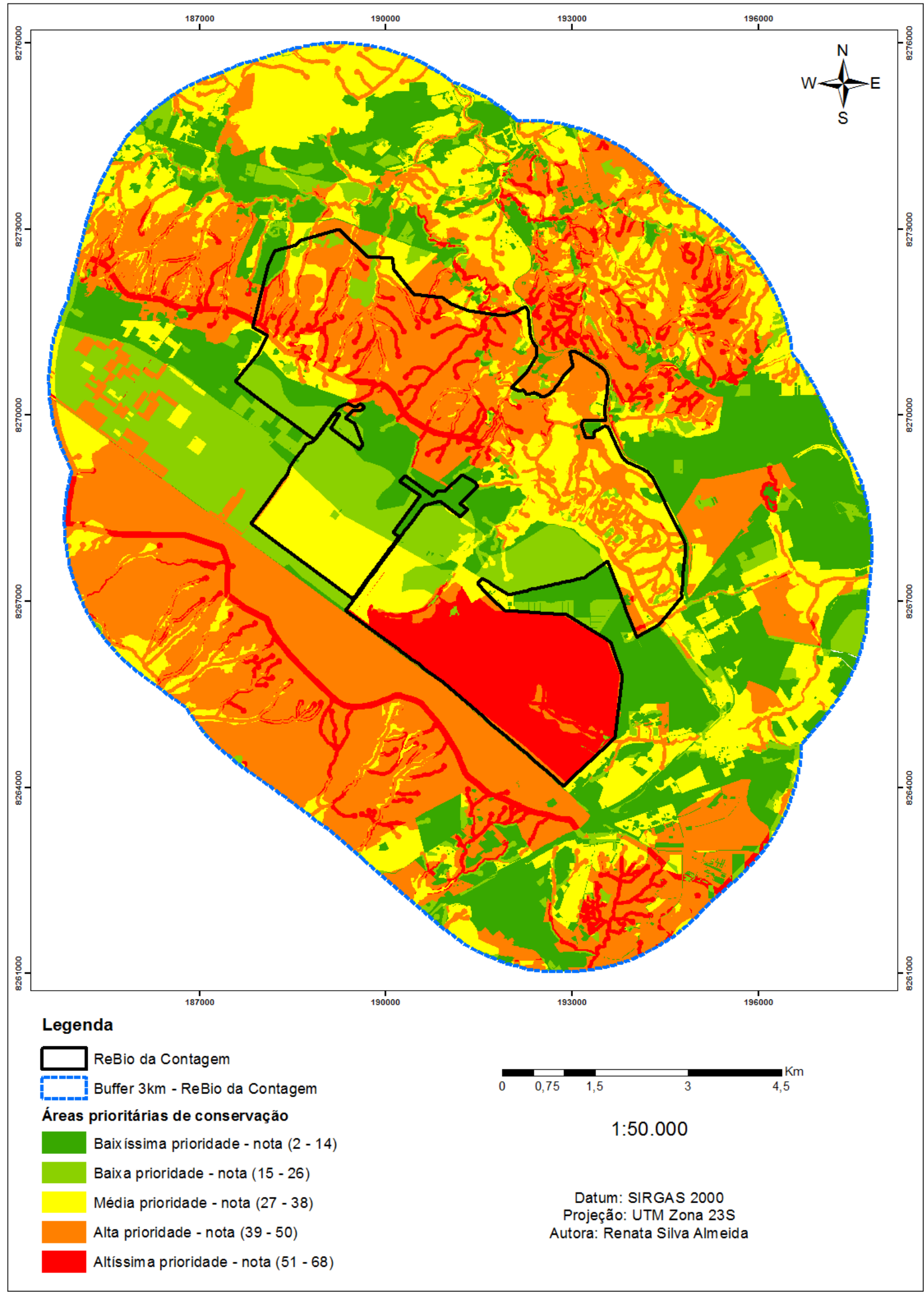

Figura 21. Mapa de áreas prioritárias de conservação sob a perspectiva da preservação ambiental.

Fonte dos dados: Terracap 2010; ICMBio 2015. 
Observando-se este mapa e a tabela de áreas prioritárias de conservação, nota-se que a maior parte dos espaços que necessitam de mais proteção são áreas de vegetação natural, que constituem grandes fragmentos de área verde sem ou com quase nenhuma intervenção humana, estas áreas, com certeza, são primordiais para a manutenção da biodiversidade, do equilíbrio ecológico e dos recursos naturais da região, e a maior parte delas já se encontram sob domínio de Unidades de Conservação de proteção integral, fazendo parte ou da ReBio da Contagem ou do PARNA Brasília (Figura 2).

As áreas que possuem maior declividade no terreno (Figura 9), também aparecem com prioridade média à altíssima de conservação. Essas são regiões de grande sensibilidade ambiental por apresentarem maior vulnerabilidade para ação do intemperismo e erosão (BRASIL, 2007), além disso, são regiões que apresentam maior fluxo de drenagens e intercalados com esta vegetação do tipo mata seca (APÊNDICE A), tipo fitofisionômico alvo de exploração tanto por sua madeira, como pela riqueza do solo onde é encontrada (RIBEIRO e WALTER, 2016), sendo necessárias maiores medidas preservativas.

Os locais de baixa e baixíssima prioridade aparecem em sua maioria nas áreas urbanizadas, áreas de solo exposto e industriais, porém há regiões entre elas que são de suma importância para a ReBio da Contagem, como para a própria Chapada, que é a área correspondente à região de topo de chapada, onde parte dela inclusive pertence à Reserva (Figura 8). São áreas de grandes altitudes e importância na recarga dos aquíferos por conta das chuvas, apresentam elevados índices pluviométricos (Figura 5) e manutenção de temperaturas mais amenas. Com o crescimento da ocupação na região do NRLO essas áreas apresentam tendências cada vez maiores de redução de seu potencial ecológico.

Observando o mapa é possível verificar que a apresentação da região de topo da chapada, bem como alguns outros pontos que não se referem a ocupações e áreas construídas, apresentaram valores abaixo dos esperados como áreas de prioridade de conservação. Isso é explicado pelo fato de que os critérios 1 e 2 tiveram grande influência no peso do diagnóstico apresentado e estes são critérios que abrangem somente áreas de vegetação natural em sua verificação. Sendo assim, alguns locais dentro da própria Reserva que são classificados em seu mapa de uso como áreas de pastagem, embora não estejam mais atuando como pasto e tenham mais valor ecológico, acabaram sendo classificadas como regiões de baixa ou baixíssima prioridade.

A Tabela 22 traz estes mesmos valores, porém invertidos para análise sob a perspectiva da gestão ambiental, onde as áreas com maior prioridade de atuação encontram-se 
classificadas como áreas de uso antrópico (99,92\% e 81,71\%), enquanto na classificação de baixa e baixíssimas prioridades são $100 \%$ áreas de uso natural.

Tabela 21. Classificação final de prioridade de conservação das áreas da ReBio da Contagem sob perspectiva da gestão.

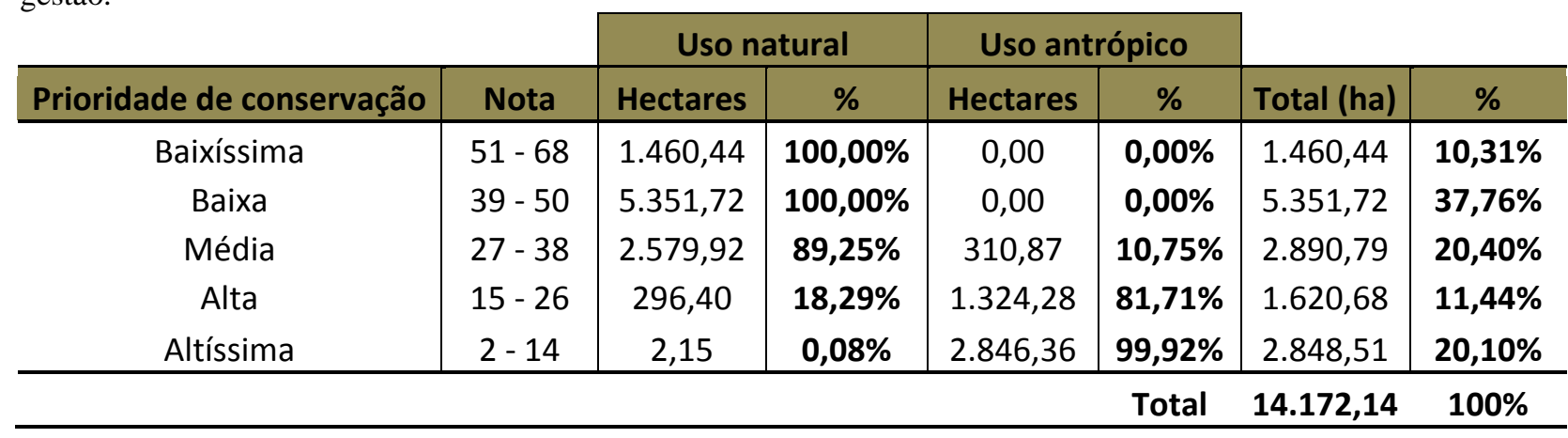

O mapa seguinte corresponde às áreas prioritárias para ações de gestão ambiental, onde aparecem como prioritárias as regiões com mais problemáticas ambientais (Figura 22). 


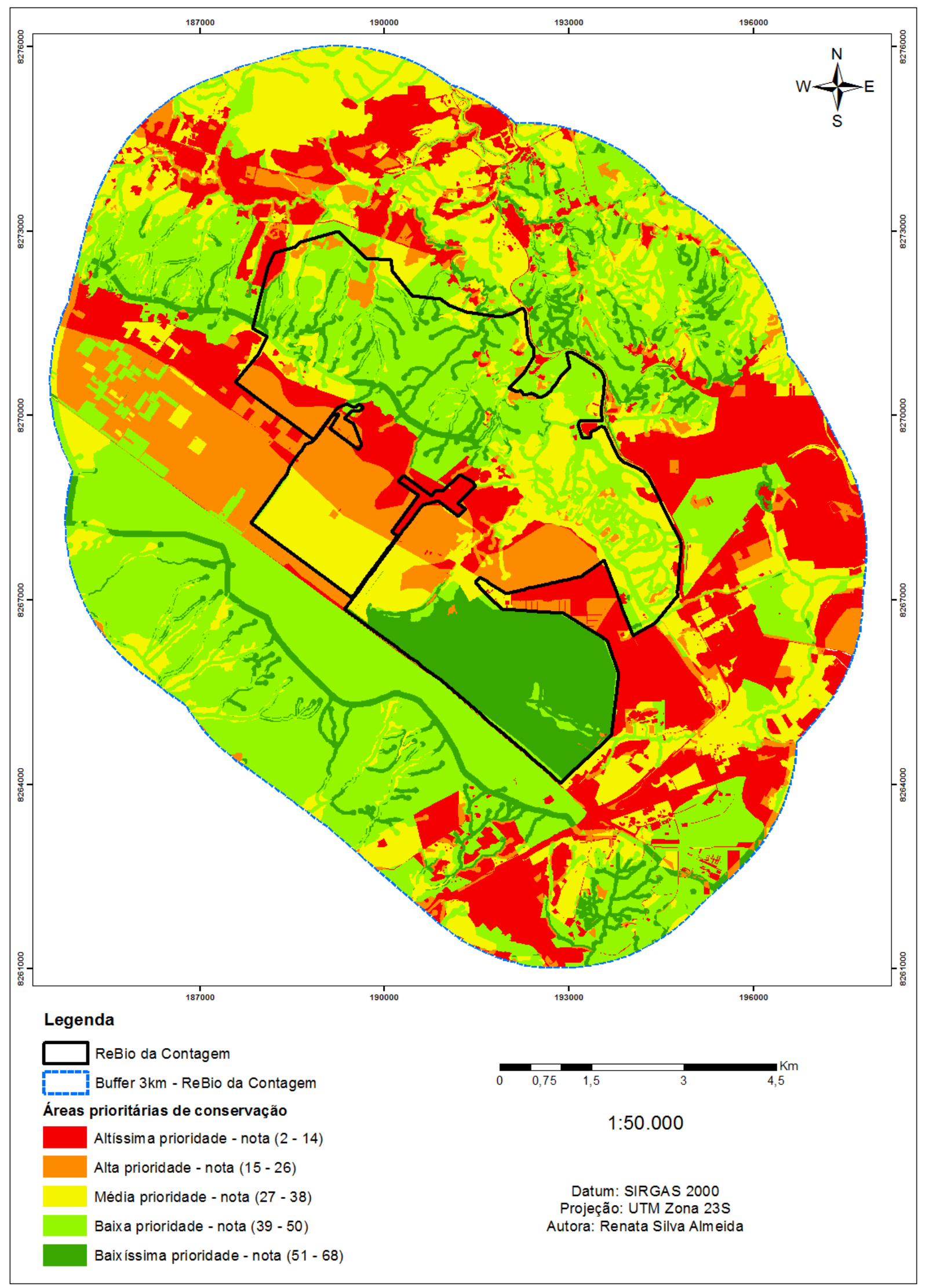

Figura 22. Mapa de áreas prioritárias de conservação sob a perspectiva da gestão ambiental.

Fonte dos dados: Terracap 2010; ICMBio 2015. 
As figuras 21 e 22 correspondem aos mesmos dados, porém visualizados de maneiras opostas. Os valores de prioridade foram invertidos para uma abordagem sob diferentes perspectivas de conservação para a promoção da sustentabilidade, pois para que esta proposta apresente resultados concretos é necessário além da proteção aos espaços mais conservados, medidas para reduzir prejuízos ambientais oriundos dos locais mais problemáticos.

As áreas que aparecem em destaque no mapa da Figura 22, são áreas com prioridade ação imediata e estas são em sua maioria áreas urbanizadas, industriais e com presença de solo exposto. São locais em que o trabalho de gestão ambiental precisa ocorrer com mais urgência e de modo mais expressivo.

É muito importante ter a atenção voltada principalmente para as áreas prioritárias que ocupam uma faixa extensa no topo da chapada, que preocupa pela crescente ocupação. Conforme entrevista (APÊNDICE A) o problema de aumento de áreas urbanizadas e parcelamento de lotes sobrecarregam a pressão sobre a Reserva e podem trazer consequências mais graves para todo o ecossistema que tem sua permanência sustentada pela presença e conservação da área de chapada.

\subsection{A RESERVA BIOLÓGICA DA CONTAGEM E AS DIMENSÕES DA SUSTENTABILIDADE}

Observando as dimensões abrangentes da sustentabilidade (social, econômica, política e ecológica) para a área de estudo, é possível verificar diversos fatores de peso negativo que geram consequências instáveis e limitantes (ODUM, 1988) para a biodiversidade da UC. Entre os fatores negativos é possível citar exemplos para todas as dimensões.

A área da Vila Basevi e as moradias presentes no interior da Reserva, que também se apresentaram como áreas de altíssima e alta prioridades, exercem forte influência de borda que é gerada para o interior da ReBio. Este fator interfere na parte da sustentabilidade ligada à dimensão social.

A população habitante em sua maioria não tem nem conhecimento de que a área ao redor de suas casas é uma Unidade de Conservação ou o que isto possa significar Shiraishi (2011). As moradias que se estendem também nos arredores, que junto com outros tipos de ocupações igualmente exercem pressão sobre a Reserva e colaboram para aumento dos 
problemas ambientais. A falta de acesso à educação e o baixo grau de instrução de parte dos habitantes nas proximidades da UC também dificultam a compreensão de como as ações do ser humano impactam diretamente sobre o meio ambiente (LINS, 2012).

$\mathrm{Na}$ dimensão econômica faltam recursos financeiros para melhoria da infraestrutura e instalações da própria UC (Apêndice A). Além disso, o próprio contexto no qual a ReBio da Contagem se encontra inserido também tem relação com essa dimensão econômica ligada à social. A má distribuição de renda no país acarreta em consequências como o crescimento desordenado das cidades e povoamento em regiões como estas ao redor da UC, que também são frutos de oportunidades de trabalho no local, da falta de recursos financeiros para populações de renda mais baixa para a construção de moradias em locais adequados ou regularizados ou com uma infraestrutura mínima de saneamento básico e até mesmo para deslocamento do trabalho para residência e vice-versa.

A dimensão política, que vem ganhando bastante embasamento com a formulação de leis, criação de órgãos governamentais e não governamentais de proteção ao meio ambiente e movimentos pró-ambientalistas, ainda conta com dificuldades no cumprimento de medidas já elaboradas para a conservação ambiental, além de sofrer com a corrupção que impera no Brasil provocando desvio de verbas destinadas para ações ambientais e com a autorização de condutas que geram resultados prejudiciais ao meio ambiente e à conservação da biodiversidade, além da vista grossa mediante suborno para a fiscalização de atividades prejudiciais ao meio ambiente.

A dimensão ecológica da sustentabilidade tem como meta a manutenção das condições ambientais existentes para que a humanidade possa subsistir pelo maior período de tempo possível, para isto é imprescindível a proteção e conservação da biodiversidade (HOROWITZ, 2003). Para a manutenção da biodiversidade na ReBio da Contagem é preciso eliminar os fatores contrários a sua riqueza biológica, mas também se faz necessário o estabelecimento de um plano de manejo para a área para averiguação de eventuais problemas, dificuldades e para propor melhorias e soluções.

Ainda na dimensão ecológica, englobando uma análise espacial e em comparação com a teoria de biogeografia de ilhas, é possível verificar certas características presentes na UC de estudo, inapropriadas para uma UC, como o tamanho da Reserva que é de apenas 3.000 ha, sendo que uma área ideal para comportar espécies variadas deveria ter ao menos 100.000 ha (PRIMACK e RODRIGUES, 2001); o formato da UC onde o ideal seria o circular para diminuir o efeito de borda e preservar o centro da UC, porém a ReBio da Contagem 
apresenta uma reentrância pela presença de área urbana justo em seu centro, o que acaba tornando este efeito potencializado; e o isolamento da Unidade de Conservação, mesmo estando esta localizada vizinha à outra UC de grande riqueza biológica, o Parque Nacional de Brasília (separadas por uma rodovia). 


\section{CONSIDERAÇÕES E RECOMENDAÇÕES FINAIS}

Com o propósito de proteção da ReBio da Contagem e de seu entorno e com o foco de atenção voltado principalmente para as áreas destacadas como mais importantes para a conservação, são propostas estratégias para a promoção da sustentabilidade.

Uma medida estratégica para promover a sustentabilidade da região é a implantação de corredores ecológicos a fim de favorecer a conexão de fragmentos de vegetação natural, para ampliação da área de vida de animais e aumentar o fluxo gênico das espécies (BRASIL, 2000a).

A proposta é criar corredores ecológicos tanto em ambientes de cerrado, englobando em alguns trechos vegetações mais ralas, como também em ambientes constituídos por faixas marginais de cursos d'água e mata de galeria e a região da Reserva da Contagem apresenta um grande potencial para esta medida estratégica, pois está rodeada de fragmentos de vegetação que permitem conexão com outras Unidades de Conservação como o PARNA Brasília e a ESECAE. É interessante também desenvolver condições favoráveis para a implantação desses corredores, pois há trechos em que são necessárias ampliações das áreas de árvores e grupos de arbustos para que o corredor tenha umas atuação mais eficiente (ME, 2003).

Outra maneira de conexão direta da ReBio da Contagem com o PARNA Brasília, seria a construção de passagens inferiores de fauna na estrada DF - 001, que corta as duas UCs, possibilitando dessa maneira o deslocamento de fauna, sem prejudicar o deslocamento humano e vice-versa, diminuindo dessa maneira as perdas de fauna por atropelamento. As passagens para fauna contribuem para o aumento da permeabilidade da paisagem, pois possibilita que os animais possam se locomover em diferentes cenários, aumentando sua dispersão e fluxo genético (CORLATTI et al., 2009). Este mecanismo de passagem aliado a outras medidas para o direcionamento correto da fauna para as passagens inferiores apresentam resultados muito positivos e eficientes, como nos trabalhos de Lodé (2000) e Abra (2012).

Não é possível falar em estratégias de sustentabilidade sem envolver os órgãos ambientais responsáveis pelas áreas abrangidas e a comunidade local. Pois, por mais que várias providências sejam tomadas para mitigar os impactos ambientais e sejam propostas medidas de restauração ecológica, sem o apoio e a ação das equipes ambientais e cidadãos que convivem diariamente com os problemas e necessidades locais, conhecem bem a região, 
lidam diretamente com situações típicas do local e são os principais responsáveis pelas alterações e pressões existentes, as propostas de cunho ambiental não surtirão o efeito desejado e não passarão de propostas.

Para o governo e órgãos responsáveis pela conservação ambiental da área da Reserva, são de grande importância a elaboração de estratégias a longo prazo nos segmentos político, operacional e educacional. Uma estratégia que pode apresentar resultados significantes para a Reserva é a de apoiar a criação de projetos de sustentabilidade e conservação da biodiversidade nas comunidades vizinhas à ReBio, como os que já vem ocorrendo (APÊNDICE A), porém com o diferencial de serem custeados por meio de compensações ambientais de empresas com atividades nas proximidades da Reserva, tal como com demais empresas instaladas no DF, que se enquadrem entre as que apresentam significativo impacto ambiental, como previsto na Resolução n 371 do CONAMA (CONAMA, 2006).

Ações em localidades que se encontram vizinhas às UCs apresentam melhores resultados devido à influência do seu campo de ação. Além desse incentivo de custear os projetos, os que apresentarem os melhores resultados, ou de grande relevância para a sustentabilidade UC deveriam receber uma premiação também em dinheiro, isso estimularia muito mais as pessoas da comunidade no envolvimento com as questões ambientais e também os auxiliaria na compreensão da importância de conservação do meio ambiente.

A parte de saneamento ambiental também não pode ficar de fora. É inviável propor estratégias sustentáveis quando grande parte das residências não apresentam condições sanitárias ideias para o meio ambiente. Seria necessária uma atuação junto ao governo para que as condições de saneamento nos locais legalmente destinados para moradias sejam reguladas.

A parte operacional está relacionada com as atividades desenvolvidas pelos órgãos responsáveis pela atuação direta na região da UC e envolve diretamente a parte de gestão ambiental. Para evitar maiores distúrbios aos recursos hídricos na região é necessário reforçar a atuação de fiscalização por meio das autoridades competentes nas áreas de APPs, tanto para evitar a construção de moradias e a exploração de recursos desses locais, como também para promover a restauração de áreas já degradadas. A Figura 23 ilustra o exemplo de situações de ocupação em área de APP, localizada no interior da Reserva da Contagem. 


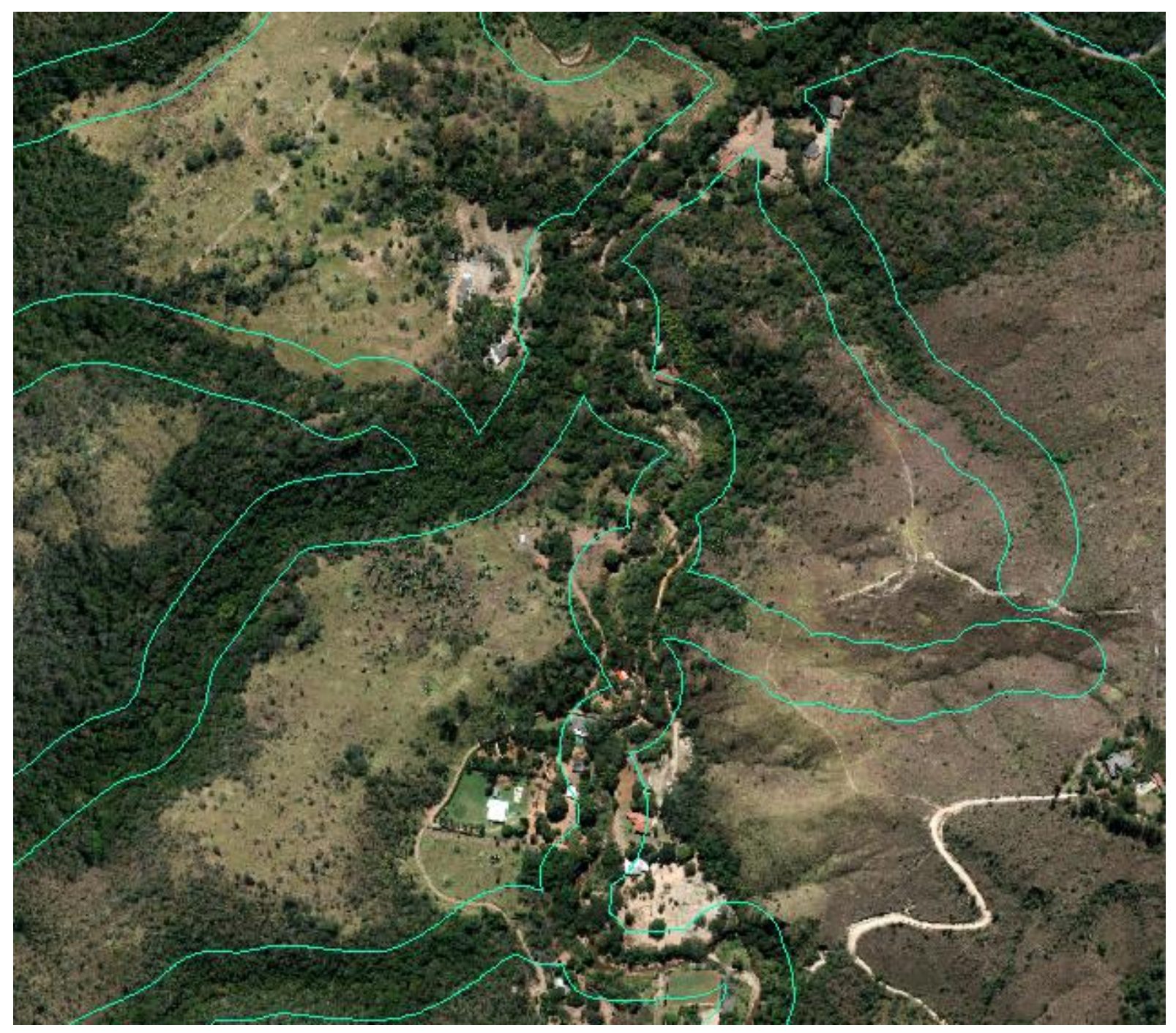

Figura 23. Área de APP demarcada pelos limites em azul, com a presença de várias moradias em seu interior. Escala de visualização 1: 6.000. Fonte: Terracap 2014.

É muito importante este trabalho de atuação no sentido de conter a aproximação de ocupações antrópicas para estas regiões, além de servir também para informar à população local os motivos para esta restrição, que muitas das vezes não estão cientes de tais legislações ambientais.

O acompanhamento do curso destas atividades, tal como das demais ações voltadas para sustentabilidade também fazem parte das ações estratégicas e que vão além do monitoramento, mas envolvem também uma série de atividades como as propostas por (CGRFA, 2013; ALFRED, 2014; ME, 2003; GTZ, 2006) que incluem o treinamento e formação de equipes, uma rede de trabalho com outros órgãos, entidades, empresas privadas, ONGs e demais grupos interessados pela sustentabilidade do local, uma comunicação 
estratégica, a gestão de conflitos, a ampliação e intensificação de atividades para melhoria do conhecimento e sensibilização do público. É importante também estimular a pesquisa na região a fim de levantar maiores informações sobre a situação atual e características da UC e as tendências do uso e ocupação do solo. Sempre que possível, procurando integrar os objetivos, econômicos, sociais e ambientais. Para isto a formulação de uma gestão ambiental eficiente é imprescindível.

Localmente, outra maneira de colaborar com a Reserva da Contagem seria definir uma zona de amortecimento, como a representada no buffer delimitado neste trabalho, mas com extensão menor que o raio de $3 \mathrm{~km}$, seria como uma integração entre a UC com áreas adjacentes, mas que envolva o local com critérios de sustentabilidade. Seria como uma área de contenção, para frear hábitos invasivos das populações vizinhas, como o que ocorre no Condomínio Rural Mansões do Colorado, onde existe uma porta na grade que separa o condomínio da ReBio da Contagem e que permite acesso ao moradores para as cachoeiras da Reserva e pequenas quedas d'água (Figura 24), como se a Reserva fizesse parte do quintal de suas casas.
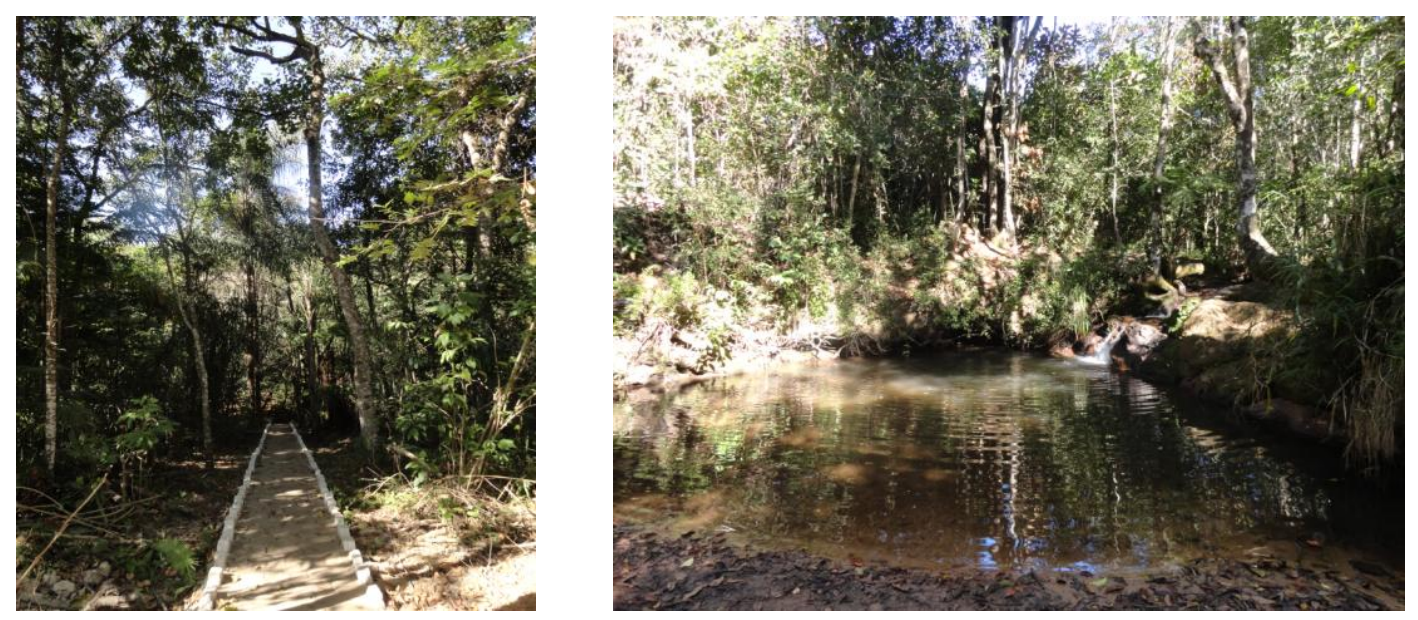

Figura 24. Trilha do Condomínio Rural Mansões do Colorado no interior da Reserva, que dá acesso a cursos d'água. (Almeida, 2016)

A delimitação dessa zona de amortecimento deve ter atuação conjunta com a população em prol da sustentabilidade, em que os residentes dessa área seriam considerados como "guardiões do meio ambiente" esse nome tem a proposta de ser utilizado como estímulo para que a população dessa região se sinta mais interessada em colaborar com a proteção do ambiente local. Para estar apta a isso a população receberia instruções sobre a importância da Reserva e em especial de sua moradia para colaborar com a conservação da biodiversidade. 
Uma boa maneira de se aplicar esta estratégia pode ser feita em áreas rurais, como nas moradias do NRLO adjacentes à ReBio da Contagem, por meio ações que visam intensificar a implementação de formas de agricultura que contribuam para conservação e uso sustentável da biodiversidade, abordando o ecossistema como os sistemas agroflorestais, que influenciam a diversidade de espécies na paisagem (ME, 2003; CGFRA, 2013).

Outra maneira é o incentivo do plantio de espécies nativas do cerrado em meio a esses sistemas e nos quintais de suas casas. Funciona como o propósito de Brandon (1997), de que a ideia é permitir o uso de recursos para que as pessoas valorizem os mesmos e assim ajudem em sua conservação; pois não haveria uma real moeda de troca para os moradores destas áreas, a compensação seria provinda pelo próprio ambiente.

A parte de educação talvez seja a mais importante de todas no contexto da Reserva da Contagem. Conforme GTZ "Uma estratégia eficaz requer uma abordagem centrada nas pessoas" (GTZ, 2006, p.15). A população precisa estar ciente da importância ecológica da região onde vivem e trabalham e de sua conservação, bem como conscientes de sua intervenção sobre o meio ambiente e prejuízos que podem causar ao mesmo e que estes refletem sobre suas vidas. de acordo com (ALFRED, 2014). O entendimento ou conhecimento da comunidade é uma das condições necessárias para o planejamento para o desenvolvimento sustentável.

Um trabalho de educação ambiental é de grande valia para salientar a necessidade da Unidade de Conservação no local e para que ações sustentáveis possam ser postas em prática. Para isso é preciso que haja mobilização social e significativa participação da comunidade, dos líderes de opinião e também das demais partes interessadas. A participação ampla ajuda a abrir o debate a novas ideias e fontes de informação, ela ajuda a expor questões que precisam ser abordadas, permite que problemas, necessidades e preferências sejam expressas, identifica as capacidades necessárias para enfrentar eles e desenvolver um consenso sobre a necessidade de ação que leva a uma melhor implementação, sem contar que a inclusão das pessoas em atividades locais e quando possível envolvê-las também em trabalhos na região, ganha apoio em todos os níveis e colabora para o desenvolvimento local (FEARNSIDE, 2011; CHIARAVALLOTI et al., 2015; GTZ, 2006).

Nesse aspecto também é interessante a proposta de levar a educação ambiental de forma lúdica para a comunidade, através de brincadeiras, jogos, teatro, arte, pois isso facilita o aprendizado, contempla todas as idades e todos os níveis de escolaridade, traz empatia para com as questões ambientais e pode ajudar a enfraquecer bloqueios e aversões da população, 
que tem dificuldade de compreender certas limitações de acesso impostas para a proteção do meio ambiente.

Outra maneira de também promover a educação de modo eficiente, como proposto em (ME, 2003) é a abordagem de conteúdos relativos ao meio ambiente, sua conservação e uso sustentável da biodiversidade nos currículos do sistema educacional, o que inclui nesta vertente, primeiramente, a capacitação de professores.

A metodologia aplicada respondeu de modo favorável ao proposto, porém, como alguns critérios eram exclusivos de áreas de uso natural, algumas regiões classificadas como uso antrópico apresentaram pouca prioridade de conservação por não conseguirem obter pontuação, mesmo as que são super importantes por sua localização e função ecológica. Isto leva à reflexão de que para obtenção de um resultado mais equivalente talvez seja interessante o estabelecimento de critérios também exclusivos para áreas antrópicas, para que cada polígono avaliado na área de estudo tenha as mesmas possibilidades de pontuação ( notas de 2 a 70), ou dividir a análise das áreas prioritárias de uso natural das de uso antrópico.

A metodologia aplicada apresentou a área de estudo com mudanças muito bruscas de prioridade de conservação, este pode ser um fator limitador na atuação das estratégias de sustentabilidade.

Para uma melhor eficiência do critério 3 e como sugestão para trabalhos futuros, poderiam ser realizadas coletas de água em diversos pontos da Reserva, que pela limitação de recursos não foram realizadas neste trabalho. Através dessas amostras coletadas em pontos específicos é possível verificar de fato o quanto as ocupações interferem sobre a UC.

Outra sugestão para continuidade deste trabalho seria o de mapeamento das áreas de vida de espécies-chave e espécies guarda-chuva que habitam a Reserva da Contagem, como fator de prioridade de conservação dessas áreas, tendo em vista a grande importância e equilíbrio ecológico que estas espécies representam. O levantamento de espécies encontradas na área da Reserva também contribui para o estabelecimento de locais prioritários.

A possibilidade de alteração do status da UC de Reserva Biológica para Parque Nacional, conforme Apêndice A, pode trazer benefícios para a própria gestão da UC, para que aumentem os recursos financeiros através do pagamento para acesso ao local, pois os recursos estando limitados acabam afetando em várias medidas de proteção ambiental. Esta mudança também pode melhorar a relação da comunidade com a UC, pois o contato com o meio ambiente, aliado à educação e sensibilização ambiental podem modificar a prática de comportamentos inadequados e impactantes. 
Todavia, rebaixar o grau de proteção de uma UC é uma alternativa negativa no sentido da proteção ambiental, pois o acesso frequente de pessoas sempre traz interferências a um meio ambiente equilibrado e somente alterar seu status não traz solução para o problema. A atuação do ICMBio e IBAMA vem trazendo bons e significantes resultados ao local desde a criação da Reserva, mas, enquanto houver dificuldades como falta de pessoal, falta de recursos financeiros, falta de fiscalização adequada, permanência de pessoas morando na área da UC, que devido à falta de orçamento dos cofres públicos para indenizá-las continuam com o direito de permanecerem no local, casas sem saneamento básico, população sem discernimento dos impactos de suas ações e presença, as condições do local permanecerão as mesmas.

A legislação brasileira opera de forma muito lenta e demanda muita burocracia, o que também prejudica a gestão ambiental local. Por isso é necessário se traçar estratégias de curto, médio e longo prazos para alcançar os objetivos e trabalhar com ações de sustentabilidade e prioridades de conservação de modo contínuo, eficaz e duradouro. Adequando-se o sistema de gestão ambiental da área e tendo essas questões como premissas, o resultado de se obter uma UC protegida e sustentável será muito mais exequível. 


\section{REFERÊNCIAS BIBLIOGRÁFICAS:}

ABES - ASSOCIAÇÃO BRASILEIRA DE ENGENHARIA SANITÁRIA E AMBIENTAL SEÇÃO SÃO PAULO. Impactos das alterações no Código Florestal. São Paulo, SP. 2012.

ABNT. ABNT NBR ISO 14001:2004 - Sistemas da gestão ambiental - Requisitos com orientações para uso 27 p. Disponível em: < http://pt.slideshare.net/mjmcreatore/nbr-iso14001-2004-gesto-ambiental-requisitos> Acesso em: 07 out. 2015

ABRA, F.D. Monitoramento e avaliação das passagens inferiores de fauna presentes na rodovia SP-225 no município de Brotas, SP. Dissertação (Mestrado) - Departamento de Ecologia, Instituto de Biociências, Universidade de São Paulo. 2012.

ALBUQUERQUE, L.G. Criação da Unidade de Conservação. In: FONSECA, Fernando Oliveira. Águas Emendadas. Brasília : Secretaria de Desenvolvimento Urbano e Meio Ambiente, Brasília, 2008.

ALFRED, E. National strategy for sustainable development and post 2015 development planning in Tanzania. Stellenbosch University, Republic of South Africa, October, 2014.

ALMEIDA, R.S. Fotografias da Reserva Biológica da Contagem e áreas limítrofes. Sobradinho, DF. 2016. 5 fotografias.

AMORIM, A.S.R. 2009. Sustentabilidade: entre a utopia, a prática e a estratégia empresarial. UDESC, SC. 2009, 155 f.

AMORIM, R.R.; OLIVEIRA, R.C. As unidades de paisagem como uma categoria de análise geográfica: o exemplo do município de São Vicente-SP. Sociedade \& Natureza, Uberlândia, 20 (2): 177-198, DEZ. 2008.

ANA - Agência Nacional de Águas. Panorama da qualidade das águas superficiais no Brasil / Agência Nacional de Águas, Superintendência de Planejamento de Recursos Hídricos. Brasília, 2005.

ANDRADE, F.G.B. Efeitos da pressão antrópica e urbanizadora sobre as Áreas de Preservação Permanente das Lagoas Costeiras - o caso da lagoa dos Quadros, costa norte do Estado do Rio Grande do Sul/Brasil. Trabalho de Especialização. Instituto de Biociências. Universidade Federal do Rio Grande do Sul. UFRGS. Porto Alegre. 2012.

ANDRADE RAMOS, J. R. Reconhecimento Geológico no Território do Rio Branco. Rio de Janeiro:DGM, 1956. p. 58-62. (Relatório Anual) AR

ANGELINI, R. Ecossistemas e Modelagem ecológica. In: Marcelo L M Pompeo. (Org.). Perspectivas da Limnologia no Brasil. 1 edição. São Luís (MA): Gráfica e Editora Uniào, 1999, v. 1, p. 1-19.

ANSOFF, H. I. Estratégia empresarial. São Paulo, SP: Mc Graw-Hill do Brasil. 1977. 203 p. 
BAPTISTA, G.M.M. Caracterização climatológica do Distrito Federal. In: Inventário hidrogeológico e dos recursos hídricos superficiais do Distrito Federal. Brasília: IEMA/SEMATEC/UnB, 1998. Vol. 1, p. 187 - 209.

BAPTISTA, G.M.M. Caracterização climatológica da APA de Cafuringa. In: APA de Cafuringa: a última fronteira natural do DF. Brasília, SEMARH. 2006. p .35 - 40.

BARBIERI, J. C. Gestão ambiental empresarial: conceitos, modelos e instrumentos. $2^{\text {a }}$ edição. São Paulo: Editora Saraiva, 2007.

BARBOSA O.; BATISTA M.B.; DYER R.C.; BRAUN O.P.G.; COTTA J.C. 1969. Projeto Brasília-Goiás: Geologia e inventário de recursos minerais (s.1), DNPM/PROSPEC, 2v. 1969.

BERRY, J.K. GIS Modeling and analysis. In: Manual of Geographic Information Systems. Edição Marguerite Madden. American Society for Photogrammetry, Bethesda, Maryland, USA, 2009.

BERTRAND, G. Paisagem e geografia física global. Esboço metodológico. Revista RA`E GA, Curitiba, n. 8, p. 141-152, 2004. Editora UFPR

BETANCUR, M.O. Análise da silvicultura na bacia hidrográfica do rio Jaguarão (BrasilUruguai): diagnóstico para a gestão geoambiental em bacia transfronteiriça. Dissertação de Mestrado - UnB-IH-GEA, Distrito Federal 2015.

BRAGA, V.D. 2010. O papel dos espaços protegidos privados para a conservação da biodiversidade. Centro de Desenvolvimento Sustentável. Universidade de Brasília. Brasília, DF. 2010

BRANDON, K. Policy and practical considerations in land-use strategies for biodiversity conservation. In: Last Stand: Protected Areas and the Defense of Tropical Biodiversity. Cap. 5. Oxford University Press, 1997.

BRANDON, K.; FONSECA, G.A.B.; RYLANDS, A.B. SILVA, J.M.C. Brazilian Conservation Challenges and Opportunities. Conservation Biology, 19 595-600 Volume 19, No. 3, June 2005

BRASIL. Lei No 6.902/1981. 1981. Disponível em: <http://www.planalto.gov.br/ccivil_03/Leis/L6902.htm> Acesso em: 21 out. 2015.

BRASIL. Lei No 6.938/1981. 1981a. Disponível em: <http://www.planalto.gov.br/ccivil_03/leis/L6938.htm> Acesso em: 19 abr. 2016.

BRASIL. Decreto $\mathbf{n}^{\circ} \mathbf{8 9 . 3 3 6 / 1 9 8 4}$ 1984. Disponível em: <http://www.planalto.gov.br/ccivil_03/decreto/1980-1989/D89336.htm> Acesso em: 19 abr. 2016. 
BRASIL. Decreto $\mathbf{n}^{\circ}$ 91.145/1985. 1985. Disponível em: < http://www2.camara.leg.br/legin/fed/decret/1980-1987/decreto-91145-15-marco-1985441412-publicacaooriginal-1-pe.html> Acesso em: 20 mai. 2016.

BRASIL. CONSTITUIÇÃO DA REPÚBLICA FEDERATIVA DO BRASIL DE 1988. 1988. Disponível em: <http://www.planalto.gov.br/ccivil_03/Constituicao/Constituicao.htm> Acesso em: 22 out. 2015.

BRASIL. Lei $\quad \mathbf{n}^{\mathbf{7}} \quad \mathbf{7 3 3 5} / \mathbf{1 9 8 9} .1989 . \quad$ Disponível em: <http://www.planalto.gov.br/ccivil_03/Leis/L7735.htm> Acesso em: 22 out. 2015.

BRASIL. Decreto $\mathbf{n}^{\mathbf{9}} \mathbf{9 8 . 9 1 4 / 1 9 9 0}$ 1990. Disponível em: <http://www.planalto.gov.br/ccivil_03/decreto/1990-1994/D98914.htm> Acesso em: 16 out. 2015

BRASIL. Lei $\mathbf{n}^{\mathbf{7}} \quad \mathbf{7 4 2 / 1 9 9 4}$ 1994. Disponível em: <http://www.tc.df.gov.br/SINJ/Arquivo.ashx?id_norma_consolidado=48701> Acesso em: 22 out. 2015.

BRASIL. MINISTÉRIO DO MEIO AMBIENTE. 1997/2002. RESERVA BIOLÓGICA DE UNA: Plano de Manejo. Brasília: IBAMA, 1997/2002. 241 p. (Encarte, 2). Disponível em: $<$ http://www.icmbio.gov.br/portal/images/stories/imgs-unidadescoservacao/ReBio\%20Una.pdf> Acesso em 05 nov. 2015.

BRASIL. Lei $\quad \mathbf{n}^{\mathbf{0}} \mathbf{9 . 6 0 5 / 1 9 9 8}$ 1998. $\quad$ Disponível em: < http://www.planalto.gov.br/ccivil_03/leis/L9605.htm> Acesso em: 10 jun. 2016.

BRASIL. MINISTÉRIO DO MEIO AMBIENTE. A Convenção sobre a Diversidade Biológica - CDB. Brasília: MMA, 2000. 30 p.

BRASIL. Lei $\mathbf{n}^{\mathbf{9}} \mathbf{9 . 9 8 5 / 2 0 0 0}$ (SNUC). 2000a Disponível em: <http://www.planalto.gov.br/ccivil_03/LEIS/L9985.htm> Acesso em: 24 out. 2015.

BRASIL. Decreto de 13 de dezembro de 2002. 2002. Disponível em: <http://www.planalto.gov.br/ccivil_03/DNN/2002/Dnn9779.htm> . Acesso em Nov/2014

BRASIL. MINISTÉRIO DO MEIO AMBIENTE. Gestão Ambiental no Brasil: compromisso com o Desenvolvimento Sustentável. 2002a.

BRASIL. MINISTÉRIO DO MEIO AMBIENTE. Última certificação dos dados pelo Órgão Gestor: $2007 . \quad$ Disponível em: <http://sistemas.mma.gov.br/cnuc/index.php?ido=relatorioparametrizado.exibeRelatorio\&rela torioPadrao $=$ true\&idUc=192> . Acesso em Nov/2014.

BRASIL. Lei complementar $\mathbf{n}^{\mathbf{0}} \mathbf{8 2 7 / 1 0}$ (SDUC). 2010. Disponível em: <http://www.fazenda.df.gov.br/aplicacoes/legislacao/legislacao/TelaSaidaDocumento.cfm?txt Numero $=827 \&$ txtAno $=2010 \&$ txtTipo $=4 \&$ txtParte $=.>$ Acesso em: 26 out. 2015 
BRASIL. Lei $\mathbf{n}^{\mathbf{1}}$ 12651/2012. 2012. Disponível em: <http://www.planalto.gov.br/ccivil_03/_ato2011-2014/2012/lei/112651.htm>. Acesso em: Nov/2014

BRASIL. MINISTÉRIO DO MEIO AMBIENTE. Disponível em: http://www.mma.gov.br/biomas/caatinga/reserva-da-biosfera Acesso em 22 out. 2015.

BRITO, M.C.W. Unidades de Conservação: intenções e resultados. $2^{\mathrm{a}}$ ed. São Paulo: Annablume: Fapesp, 2003.

BRITO, M.C.W. 2004. Apontamentos sobre a biologia da conservação. In: Terras Indígenas e Unidades de Conservação da natureza : o desafio das sobreposições / organização Fany Ricardo. - São Paulo: Instituto Socioambiental, 2004.

BURSZTYN, M. A. A. Gestão ambiental: instrumentos e práticas. Brasília: IBAMA, 1994.

BURSZTYN, M.; ARAÚJO, C.H. Da utopia à exclusão: vivendo nas ruas em Brasília. Rio de Janeiro: Garamond; Brasília: Codeplan, 1997.

CAESB. 2015. Disponível em: < http://www.caesb.df.gov.br/protecao-de-mananciais.html> Acesso em: 24 out. 2015.

CÂMARA, G.; CASANOVA, M.A.; HERMELY, A.S.; MAGALHÃES, G.C.; MEDEIROS, C.M.B. Anatorima de Sistemas de Informação Geográfica. 193 p. 1996. Disponível em: <http://mtc-m12.sid.inpe.br/col/sid.inpe.br/sergio/2004/10.07.13.36/doc/anatomia.pdf> Acesso em: 15 nov. 2015.

CÂMARA, G.; DAVIS, C. Introdução. In: Introdução à Ciência da Geoinformação. Org. CÂMARA, G.; DAVIS, C.; MONTEIRO, A.M.V. INPE. São José dos Campos, SP. 2001.

CAMPOS, J.E.G. Geologia da APA de Cafuringa. In: APA de Cafuringa: a última fronteira natural do DF. Brasília, SEMARH. 2006. p. $41-47$.

CAMPOS, J.E.G.; FREITAS-SILVA, F.H. Hidrogeologia do Distrito Federal In: Inventário hidrogeológico e dos recursos hídricos superficiais do Distrito Federal. Brasília: IEMA/SEMATEC/UnB, 1998. Parte I. Vol II.

CAMPOS, L.M.S. SGADA - Sistema de Gestão e Avaliação de Desempenho Ambiental: uma proposta de implementação. Tese (Doutorado em Engenharia de Produção) PPGEP/UFSC - Universidade de Santa Catarina,Florianópolis, SC. 2001.

CARDOSO, M.P.D.; MARCUZZO, F.F.N.; BARROS, J.R. Classificação climática de Köppen-Geiger para o estado de Goiás e o Distrito Federal. ACTA Geográfica, Boa Vista, v.8, n.16, jan./mar. de 2014. pp.40-55

CASTRO, D.M.M. Gestão ambiental, aspectos técnico-científicos e político-institucionais. Dissertação de mestrado, Universidade Federal do Rio de Janeiro, RJ. 1995.

CASTRO, K.B. Avaliação do modelo SWAT na simulação da vazão em bacia agrícola do cerrado intensamente monitorada. Instituto de Geociências, UnB. 2013. 
CARVALHO, S.S. Áreas Livres para Ocupação Urbana no Município de Salvador Uma Aplicação de Tecnologias de Geoprocessamento em Análise Espacial Urbana. Dissertação (Mestrado) - Faculdade de Arquitetura - Universidade Federal da Bahia, Salvador, 2002. 90 p. il.

CGRFA - COMMISSION ON GENETIC RESOURCES FOR FOOD AND AGRICULTURE. Draft strategic priorities for action for the conservation, sustainable use and development of forest genetic resources. Rome, 15-19 April 2013. Disponível em: < http://www.fao.org/docrep/meeting/027/mf838e.pdf> Acesso em: 25 jun 2016.

CHIARAVALlOTI, R.M.; DELELIS, C.; TOFOLI, C.; PADUA, C.V.; RIBEIRO, K.T.; MENEZES, G.A. Federal protected areas management strategies in Brazil: sustainable financing, staffing, and local development. Natureza \& Conservação - Brazilian Journal of Nature Conservation. 13 (2015) p. 30-34.

CHRISTOFOLETTI, A. Modelagem de sistemas ambientais. São Paulo, Editora Edgard Blucher LTDA. 1999.

CNUC/MMA. 2015. Disponível em: < http://www.mma.gov.br/areas-protegidas/cadastronacional-de-ucs> Acesso em 22 out. 2015.

CNUC/MMA. 2015a. Disponível em: http://www.mma.gov.br/images/arquivo/80112/CNUC_Categoria_Fevereiro_2015.pdf> Acesso em: 25 out. 2015.

CODEPLAN - Companhia de Planejamento do Distrito Federal. Atlas do Distrito Federal. $1^{\text {a }}$ edição. GDF, Brasília - DF. 1984.

CODEPLAN - Companhia de Planejamento do Distrito Federal. Pesquisa distrital por amostra de domicílios - Sobradinho - PDAD 2011. Disponível em: <http://www.codeplan.df.gov.br/images/CODEPLAN/PDF/Pesquisas\%20Socioecon\%C3\%B 4micas/PDAD/2011/PDAD\%20Sobradinho.pdf>. Acesso em Nov/2014

CONAMA. 1986. RESOLUÇÃO $\mathbf{N}^{\mathbf{0}}$ 001. Disponível em: < http://www.mma.gov.br/port/conama/res/res86/res0186.htmll> Acesso em 08 jun. 2016.

CONAMA. 1997. RESOLUÇÃO $\mathbf{N}^{\mathbf{0}}$ 237. Disponível em: <http://www.mma.gov.br/port/conama/res/res97/res23797.html> Acesso em 08 jun. 2016.

CONAMA. 2006. RESOLUÇÃO $\mathbf{N}^{\mathbf{2}}$ 237. Disponível em: <http://www.mma.gov.br/port/conama/legiabre.cfm?codlegi=493> Acesso em 05 jul. 2016.

CONAMA. 2012. RESOLUÇÃO $\mathbf{N}^{\mathbf{0}}$ 303. Disponível em: <http://www.mma.gov.br/port/conama/res/res02/res30302.html> Acesso em 08 mai. 2015.

CORLATTI, L.; HACKLANDER, K.; FREY-ROOS, F. Ability of wildlife overpasses to provide connectivity and prevent genetic isolation. Conservation Biology, s/n: 1-9 
CORRÊA, R.S.; BAPTISTA, G.M.M.. Áreas degradadas pela mineração. In: APA de Cafuringa: a última fronteira natural do DF. Brasília, SEMARH. 2006. Seção VIII, p .326 $-327$.

CRUZ, I.; CAMPOS, V. B. G. Sistemas de Informações Geográficas aplicados á análise espacial em transportes, meio ambiente e ocupação do solo. Rio de Transportes III. Rio de Janeiro, Brasil 2005.

DALAZOANA, R. Implicações na cartografia com a evolução do sistema geodésico brasileiro e futura adoção do SIRGAS. Dissertação de Mestrado. UFP, Curitiba, 2001.

DIEGUES, A.C.S. (Coord.). Conflitos entre populações humanas e Unidades de Conservação e Mata Atlântica. São Paulo: USP - NUPAUB, 1995. p. 205-283.

DRUMMOND, J. A.; FRANCO, J. L. A.; OLIVEIRA, D. Uma análise sobre a história e a situação das Unidades de Conservação no Brasil. In: GANEM, R. S. (org.). Conservação da biodiversidade: legislação e políticas públicas. Brasília, DF: Câmara dos Deputados, Edições Câmara, 2011. p.341-385.

DUNCAN, M. A. G. Gestão territorial, visões e significados. Disponível em : <http://www.academia.edu/2052742/Gest\%C3\%A3o_Territorial_Vis\%C3\%B5es_e_significa dos>. Acessado em 10 ago.2015.

EMBRAPA. Centro Nacional de Pesquisa de Solos (Rio de Janeiro, RJ). Sistema brasileiro de classificação de solos. 2. ed. - Rio de Janeiro : EMBRAPA-SPI, 2006

EMBRAPA (1978) Levantamento de reconhecimento dos solos do Distrito Federal, Boletim Técnico, no. 53, SNLCS, Rio de Janeiro, 455 p.

EMBRAPA. Mapa pedológico digital - SIG atualizado do Distrito Federal escala 1:100.000 e uma síntese do texto explicativo / Reatto, Adriana, et al., - Planaltina : Embrapa Cerrados, 2004.31 p.- (Documentos / Embrapa Cerrados, ISSN 1517-5111; n. 120)

FARIA, A. ; DARDENNE, M. A. Estratigrafia do Grupo Paranoá na região de Alto Paraíso de Goiás - São João D’Aliança - GO. In: SIMPÓSIO DE GEOLOGIA DO CENTROOESTE, 5, 1995, Goiânia. Boletim informativo. Goiânia: SBG - N.C.O., 1995. p. 75-77.

FEARNSIDE, P.M. Strategies for social and environmental conservation in conservation units. pp. 233-239. In: Miguel PinedoVasquez, Christine Padoch, Mauro Luis Ruffino \& Eduardo Brondizio (eds.) The Amazonian Várzea: The Decade Past and the Decade Ahead. Springer, New York, USA. 466 pp. 2011.

FERREIRA, S.J.F.; MIRANDA, S.A.F.; MARQUES FILHO, A.O.; SILVA, C.C. Efeito da pressão antrópica sobre igarapés na Reserva Florestal Adolpho Ducke, área de floresta na Amazônia Central. Acta Amazônica vol:42 iss:4 pg:533. 2012

FIDALGO, E.C.C. Critérios para a análise de métodos e indicadores ambientais usados na etapa de diagnóstico de planejamentos ambientais. Tese (doutorado) - Universidade Estadual de Campinas, Faculdade de Engenharia Agrícola Campinas, SP: [s.n.], 2003. 
FILHO, A.P.; CUARESMA, C.C.; RODRIGUES, T.R.I. Ação antrópica como agente transformador da organização espacial em bacias hidrográficas. Diez años de cambios en el Mundo, en la Geografía y en las Ciencias Sociales, 1999-2008. Actas del X Coloquio Internacional de Geocrítica, Universidade de Barcelona, 26-30 de maio de 2008. Disponível em: http://www.ub.es/geocrit/-xcol/277.htm. Acesso em: 10 jul. 2016.

FMCS - FÓRUM MUNDIAL DE COMUNICAÇÃO SOCIAL. LEDUR, Clarice (Coord). $\mathbf{5}^{\mathbf{0}}$ fórum mundial de comunicação social: ações de sustentabilidade ambiental. Porto Alegre: Associação Latino-Americana de Agências de Publicidade, 2008. 168 p.

FONSECA, R.L. Indicações para aplicação de um SIG simplificado para auxiliar a gestão em Unidades de Conservação no Brasil. 2012. 101 f., il. Dissertação (Mestrado em Geografia)_-Universidade de Brasília, Brasília, 2012.

FORTES, P.T.F.O.; JOFFILY, C.M.L.C.; OLIVEIRA, M.L.; BAXE, O.S.S.; ALMEIDA, W.M. Geoprocessamento aplicado ao planejamento e gestão ambiental na região do Núcleo Rural Lago Oeste, Sobradinho, Distrito Federal: resultados preliminares. In: SIMPÓSIO BRASILEIRO DE SENSORIAMENTO REMOTO, XI., 2003, Belo Horizonte. Anais... Belo Horizonte: INPE, 2003. p. 1795 - 1802.

FORTES, P.T.F.O.; OLIVEIRA, G.I.M.; CREPANI, E.; MEDEIROS, J.S. Geoprocessamento aplicado ao planejamento e gestão ambiental na Área de Proteção Ambiental de Cafuringa, Distrito Federal Parte 2: processamento de dados espaciais. In: SIMPÓSIO BRASILEIRO DE SENSORIAMENTO REMOTO, XIII., 2007, Florianópolis. Anais... Florianópolis: INPE, 2007. p. 2613-2620.

FRANCISCO, C.E.S.; COELHO, R.M.; TORRES, R.B., ADAMI, S.F. Espacialização de análise multicriterial em SIG: prioridades para recuperação de Áreas de Preservação Permanente. In: SIMPÓSIO BRASILEIRO DE SENSORIAMENTO REMOTO, XIII., 2007, Florianópolis. Anais... Florianópolis: INPE, 2007. p. 2643-2650.

FRANCO, J.L.A. The concept of biodiversity and the history of conservation biology: from wilderness preservation to biodiversity conservation. História vol. 32 no. 2 Franca jul/dez. 2013.

FREITAS-SILVA, F.H.; CAMPOS, J.E.G.; GEOLOGIA DO DISTRITO FEDERAL. In: Inventário hidrogeológico e dos recursos hídricos superficiais do Distrito Federal. Brasília: IEMA/SEMATEC/UnB, 1998. Vol 1. Cap 1

GANEM, R. S. 2007. Políticas de conservação da biodiversidade e conectividade entre remanescentes de Cerrado. CDS, Universidade de Brasília. Brasília, 2007. Disponível em <http://repositorio.unb.br/bitstream/10482/4825/1/2007_Roseli\%20Senna.pdf> Acesso em: $07 / 09 / 2015$

GELDMANN, J.; JOPPA, L.N.; BURGUESS, N.D. Mapping Change in Human Pressure Globally on Land and within Protected Areas. Conservation biology, vol:28 iss:6 pg:1604 1616. 2014 
GDF- Governo do Distrito Federal. Decreto no 18.585, de setembro de 1997. Disponível em: $\langle$ http://www.adasa.df.gov.br/images/stories/anexos/cidadao/legislacao/decreto18585.pdf $>$.

Acesso em: Nov/2014

GILBERT, M. J. ISO 14001 / BS 7750: Sistema de Gerenciamento Ambiental. São Paulo: IMAM, 1995.

GODARD, O. A gestão integrada dos recursos naturais e do meio ambiente: conceitos, instituições e desafios de legitimação. In : VIEIRA, Paulo Freire e WEBER, Jacques (orgs). Gestão de recursos naturais renováveis e desenvolvimento: novos desafios para a pesquisa ambiental. $3^{\text {a }}$ edição. São Paulo: Cortez, 2002. pp. 201-266.

GONÇALVES, T.D.; ROIG, H.L.; CAMPOS, J.E.G. Sistema de informação geográfica como ferramenta de apoio à outorga dos recursos hídricos subterrâneos no Distrito Federal. Revista Brasileira de Geociências. volume 39 (1), março de 2009.

GRUBA, M.C.; DUTRA, I.S.; STOCK, M.R.M. Acciones estratégicas de sostenibilidad socioeconómica y ambiental: estudio del eslabón productor del sector de la carne. GeAS Revista de Gestão Ambiental e Sustentabilidade. São Paulo, vol 2, n² 2, p. 24-49. Jul/Dez 2013.

GTZ. Strategic Communication for Sustainable development: A Conceptual Overview', Deutsche Gesellschaft für Technische Zusammenarbeit (GTZ), Eschborn, Germany. 2006.

HERRMANN B.C., RODRIGUES E., LIMA A. 2005. A paisagem como condicionadora de bordas de fragmentos florestais. Revista FLORESTA, Curitiba, PR, v.35, n. 1, jan.abr. 2005.

HOROWITZ, C. Sustentabilidade da biodiversidade em Unidades de Conservação de proteção integral: Parque Nacional de Brasília. 329 p. Centro de Desenvolvimento Sustentável. Universidade de Brasília, 2003.

IBRAM - Instituto do Meio Ambiente e dos Recursos Hídricos. Guia de Unidades de Conservação do Distrito Federal. - Brasília, DF, 2014.

IBRAM - Instituto do Meio Ambiente e dos Recursos Hídricos. Mapa ambiental. Brasília, 2014. 1 mapa, color. Escala 1:125.000

IBRAM. 2015. Disponível em: < http://www.ibram.df.gov.br/> Acesso em: 24 out. 2015.

ICMBIO - Instituto Chico Mendes de Conservação da Biodiversidade. Disponível em: < http://www.icmbio.gov.br/portal/unidadesdeconservacao/biomas-

brasileiros/cerrado/unidades-de-conservacao-cerrado/2101-ReBio-dacontagem?highlight=WyJyZXNlcnZhIiwiYmlvbFx1MDBmM2dpY2EiLCJjb250YWdlbSIsIn Jlc2VydmEgYmlvbFx1MDBmM2dpY2EiLCJyZXNlcnZhIGJpb2xcdTAwZjNnaWNhIGNvb nRhZ2VtliwiYmlvbFx1MDBmM2dpY2EgY29udGFnZW0iXQ==> , Acesso em: 10 mai. 2015.

ITABORAHY N. Z. A Geografia, o conceito do território e os processos de territorialização das comunidades quilombolas: Primeiras Aproximações. In: ENCONTRO NACIONAL DOS GEÓGRAFOS BRASILEIROS, XVI., 2010, Porto Alegre. Anais... Porto Alegre: Associação 
dos Geógrafos Brasileiros - $A G B, 2010 . \quad$ Disponível em: $<$ http://www.ufjf.br/nugea/files/2010/09/A-Geografia-o-conceito-do-territ\%C3\%B3rio-e-osprocessos-de-territorializa $\% \mathrm{C} 3 \% \mathrm{~A} 7 \% \mathrm{C} 3 \% \mathrm{~A} 30$-das-comunidades-quilombolas.pdf $>$ Acessado em: 10/08/2015

JACOBI, P. Educação ambiental, cidadania e sustentabilidade. Cadernos de Pesquisa, n. 118, março/ 2003

JESUS, E.N. Avaliação dos fragmentos florestais da bacia hidrográfica do rio Poxim (Sergipe - Brasil) para fins de restauração ecológica. Dissertação (Mestrado em Agroecossistemas) - Universidade Federal de Sergipe, 2013. São Cristóvão, 2013.

JBB - Jardim Botânico de Brasília. Cartas de Serviços ao Cidadão. Brasília, DF. 2015. Disponível em: < http://www.brasilia.df.gov.br/wp-conteudo/uploads/2015/10/CARTA-DESERVI\%C3\%87OS-AO-CIDAD\%C3\%83O-JBB-2.pdf >. Acesso em: 10 jun. 2016.

JBRJ - Jardim Botânico do Rio de Janeiro. Disponível em: http://jbrj.gov.br/jardim/historia. Acesso em: 18 out. 2015.

KING, L.C. A Geomorfologia do Brasil Oriental. Revista Brasileira de Geografia, IBGE, Rio de Janeiro, 18(2), p.147-266, 1956.

LANG, S.; BLASCHKE, T. Análise da paisagem com SIG. São Paulo: Oficina de Textos, 2009.

LANNA, A.E. A inserção da gestão das águas na gestão ambiental. In: Interfaces da gestão de recursos hídricos: desafios da Lei de Águas de 1997 / Héctor Raúl Muñoz, organizador. 2. ed. Brasília: Secretaria de Recursos Hídricos, 2000.

LAURANCE W.F., CAMARGO J.L.C., LUIZÃO R.C.C., LAURANCE S.G., PIMM S.L., BRUNA E.M., STOUFFER P.C., WILLIAMSON G.B., BENÍTEZ-MALVIDO J., VASCONCELOS H.L., HOUTAN K.S.V., ZARTMAN C.E., BOYLE S.A., DIDHAM R.K., ANDRADE A., LOVEJOY T.E. The fate of Amazonian forest fragments: A 32-year investigation. Biological Conservation 144 (2011) 56-67

LIMA, J. D. C. V. Análise da ferramenta arcCN runoff na simulação de infiltração e escoamento superficial de água na microbacia hidrográfica do rio capetinga Distrito Federal. 2009. Monografia de Especialização, Instituto de Geociências, Universidade de Brasília. Brasília. 50p.

LIMA, R.B. O Princípio da Participação em Gestão Ambiental: A fronteira entre gerir e gestar. In: IV Encontro da Sociedade Brasileira de Economia Ecológica, 2001, Belém. VI Encontro da Sociedade Brasileira de Economia Ecológica, 2001.

LIMA, R.N.S.; ROCHA, C.H.B. Técnicas de sensoriamento remoto e métricas de ecologia da paisagem aplicadas na análise da fragmentação florestal no município de Juiz de Fora - MG em 1987 e 2008. In: SIMPÓSIO BRASILEIRO DE SENSORIAMENTO REMOTO, XV., 2011, Curitiba. Anais... Curitiba: INPE 2011, p.2067. 
LINS, M.M.B. Mobilização comunitária visando à gestão participativa e à resolução de problemas ambientais: estudo de caso na Vila Basevi/DF. 2012. 100f. Dissertação (Mestrado) - Programa de Pós-Graduação da Faculdade de Educação da Universidade de Brasília, Brasília, 2012.

LODÉ, T. 2000. Effect of a motorway on mortality and isolation of wildlife populations. AMBIO: A Journal of the Human Environment May 2000 : Vol. 29, Issue 3, pg(s) 163 166

LOPES, G. O.; RIBEIRO, C. F. D. A.; SILVA, W. B. Mapeamento das fitofisionomias de cerrado da Reserva Biológica da Contagem, DF, por meio de sensoriamento remoto. In: SIMPÓSIO BRASILEIRO DE SENSORIAMENTO REMOTO, XIV., 2009, Natal. Anais... Natal: INPE, 2009. p. 2801-2807. 2009.

LUCAS, D.F.; FONSECA, B.M.; JESUS, J.R.P. Análise espacial dos fragmentos florestais em de São Gonçalo do Rio Abaixo - MG. In: SIMPÓSIO BRASILEIRO DE SENSORIAMENTO REMOTO, XVI., 2013, Foz do Iguaçu. Anais... Foz do Iguaçu: INPE, 2013. p. 2921-2927.

MACARTHUR, R.H.; WILSON, E.O. The theory of Island Biogeography. Princeton University Press. USA. 1967. ISBN: 0-691-08836-5

MACHADO, A.; DRUMMOND, G.M.; PAGLIA, A.P. (Ed.). Livro vermelho da fauna brasileira ameaçada de extinção.Brasília: Ministério do Meio Ambiente, 2010. 2 v. (Biodiversidade ; 19). ISBN 9788577381029.

MACHADO, R.B., M.B. RAMOS NETO, P.G.P. PEREIRA, E.F. CALDAS, D.A. GONÇALVES, N.S. SANTOS, K. TABOR E M. STEININGER. 2004. Estimativas de perda da área do Cerrado brasileiro. Relatório técnico não publicado. Conservação Internacional, Brasília, DF.

MACIEL, M.A. 2011. Unidades de Conservação: breve histórico e relevância para a efetividade do direito ao meio ambiente ecologicamente equilibrado. 2011. Disponível em http://www.ambito-

juridico.com.br/site/index.php?n_link=revista_artigos_leitura\&artigo_id=9870> Acesso em 21 out. 2015

MANCINI, G.A. Avaliação dos custos da urbanização dispersa no Distrito Federal. Faculdade de Arquitetura e Urbanismo. Universidade de Brasília. 2008.

MARTINS, E.S., BAPTISTA, G.M.M. Compartimentação geomorfológica e sistemas morfodinâmicos do Distrito Federal. In: Inventário hidrogeológico e dos recursos hídricos superficiais do Distrito Federal. Brasília: IEMA/SEMATEC/UnB, 1998. Vol. 1, p. 89-137.

MCGARIGAL, K. Fragstats Help. In: Fragstats: Spatial Pattern Analysis Program for Categorical Maps. 2015. Disponível em: < http://www.umass.edu/landeco/research/fragstats/documents/fragstats.help.4.2.pdf> Acesso em: 25 Ago. 2016. 
MCGARIGAL, K.; MARKS, B. Fragstats: spatial pattern analysis program for quantifying landscape structure. Dolores, Colorado. Versão 2. 1995. Disponível em: < http://www.umass.edu/landeco/pubs/mcgarigal.marks.1995.pdf> Acesso em: 25 ago. 2016.

ME - Ministry of Environment . A National Strategy for the Conservation and Sustainable Use of Biological Diversity - Together with an Action Programme. (Document approved by the Council of Ministers on February 25th 2003), Warsaw. 2003. Disponível em: < https://www.cbd.int/doc/world/pl/pl-nbsap-v2-en.pdf> Acesso em: 30 jun. 2016.

MEDEIROS, R. Evolução das tipologias e categorias de áreas protegidas no Brasil. Ambiente e Sociedade vol.9 no.1 Jan/June 2006.

MENDES, J. M. G. 2009. Dimensões da sustentabilidade . Revista das Faculdades Santa Cruz, v. 7, n. 2, julho/dezembro 2009

MENEZES, P. H. B. J. 2010. Avaliação do efeito das ações antrópicas no processo de escoamento superficial e assoreamento na bacia do lago Paranoá. 2010. Dissertação de Mestrado, Instituto de Geociências, Universidade de Brasília. 117p

MILANO, M.S. "Unidades de Conservação - Técnica, Lei e Ética para a Conservação da Biodiversidade". In: BENJAMIN, A.H. (Coord.) Direito Ambiental das Áreas Protegidas: o regime jurídico das Unidades de Conservação. Rio de Janeiro: Editora Forense Universitária, 2001.

MINTZBERG, H.; AHLSTRAND, B.; \& LAMPEL, J. Safári de estratégia: um roteiro pela selva do planejamento estratégico. Porto Alegre, RS: Bookman. 2000.

MINTZBERG, H.; LAMPEL, J.; QUINN, J.B.; GHOSHAL, S. O processo da estratégia: conceitos, contextos e casos selecionados. Porto Alegre: $4^{\mathrm{a}}$ edição. Brookman, 2006. 496 p.

MIRANDA, E. E. Água na natureza, na vida e no coração dos homens. São Paulo: Campinas, 2004.

MITTERMEIER, R.; FONSECA, G.A.B.; RYLANDS, A.B. \& BRANDON, K. 2005. A brief history of biodiversity conservation in Brazil. Conservation Biology, pg 601-607. Volume 19, No. 3, Junho 2005.

MMA/IBAMA/PNUD - Relatório técnico de monitoramento do desmatamento no bioma Cerrado, 2002 a 2008: Dados Revisados ACORDO DE COOPERAÇÃO TÉCNICA MMA/IBAMA/PNUD. CENTRO DE SENSORIAMENTO REMOTO - CSR/IBAMA. NOVEMBRO DE 2009.

MMA/SBF. Fragmentação de Ecossistemas: Causas, efeitos sobre a biodiversidade e recomendações de políticas públicas / Denise Marçal Rambaldi, Daniela América Suárez de Oliveira (orgs.) Brasília: MMA/SBF, 2003. 510 p.

MYERS N., MITTERMEIER R.A., MITTERMEIER C.G., FONSECA, G.A.B., KENT J. 2000. Biodiversity hotspots for conservation priorities. NATURE, VOL 403, 24 Fevereiro 2000. 
NASCIMENTO, L.C. Efetividade da criação da Reserva Biológica da Contagem (Sobradinho, Distrito Federal). UniCEUB/ICPD. Brasília, DF. 2014.

NASCIMENTO, M.I.; POGGIANI, F.; DURIGAN, G.; IEMMA, A.F.; SILVA FILHO, D.F. Eficácia de barreira de eucaliptos na contenção do efeito de borda em fragmento de floresta subtropical no estado de São Paulo, Brasil. Scientia Forestalis. Piracicaba, v. 38, n. 86, p. 191-203, jun. 2010

NETO, A. S.; CAMPOS L. M. S.; SHIGUNOV T. Fundamentos da Gestão Ambiental. Rio de Janeiro: Editora Ciência Moderna LTDA, 2009. ISBN: 978-85-7393-801-2

NETTO, P.B. Sustentabilidade ameaçada. In: APA de Cafuringa: a última fronteira natural do DF. Brasília, SEMARH. 2006. Seção VIII, p .319 - 325.

NETTO, P.B.; CARDOSO, E.S. Preservação e conservação ambiental. In: APA de Cafuringa: a última fronteira natural do DF. Brasília, SEMARH. 2006. Seção X, p .368 376.

NB BIODIVERSITY WORKING GROUP - NEW BRUNSWICK BIODIVERSITY WORKING GROUP. Biodiversity Strategy: Conserving biodiversity and using biological resources in a sustainable manner. Canada. Jun, 2009.

NICOLELlA, G.; MARQUES, J.F.; SKORUPA, L.A. Sistema de gestão ambiental: aspectos teóricos e análise de um conjunto de empresas da região de Campinas, SP. Jaguariúna: Embrapa Meio Ambiente, 2004. 42 p. (Embrapa Meio Ambiente. Documentos, 39).

NOVAES PINTO, M. Cerrado: caracterização, ocupação e perspectivas. 2. ed. Brasília : Editora Universidade de Brasília, 1994. P. 285 - 320.

ODUM, E. Ecologia. Editora Guanabara, RJ. 1988.

OLIVEIRA, D. Avaliação de Efetividade de Gestão de Unidades de Conservação: O Mosaico do Apuí - Amazonas/AM, 118 p., (UnB - CDS, Mestre, Política e Gestão Ambiental, 2012).

OLIVETTI, D., MINCATO, R. L., AYER, J. E. B., SILVA, M. L. N., CURI, N. Spatial and temporal modeling of water erosion in dystrophic red latosol (oxisol) used for farming and cattle raising activities in a sub-basin in the south of Minas Gerais. Ciência e Agrotecnologia $39,58-67$.

PEREIRA, P.H.V.; PEREIRA, S.Y.; YOSHINAGA, A.; PEREIRA, P.R.B. Nascentes: análise e discussão dos conceitos existentes. Fórum Ambiental da Alta Paulista. Org. ANAP Associação Amigos da Natureza da Alta Paulista. Vol. 2, n. 2, 2011.

PEREIRA, R. O. O papel dos Ilustrados da Comarca de Ilhéus na Regulamentação dos Reais Cortes de Madeira: 1784 - 1799. In: ENCONTRO ESTADUAL DE HISTÓRIA, III., 2006, Caetité. Anais... Caetité: UNEB, 2006. 
PNUMA - Programa das Nações Unidas para o Meio Ambiente. Disponível em: http://nacoesunidas.org/agencia/pnuma/ Acesso em: 22 out. 2015.

PRIMACK, R.B.; RODRIGUES, E. Biologia da conservação. [São Paulo]: Planta, 2001. vii, $327 \mathrm{p}$.

PROBIO (Projeto de Conservação e Utilização Sustentável da Diversidade Biológica Brasileira) do Ministério do Meio Ambiente. Mapeamento de cobertura vegetal do bioma Cerrado. Relatório final. 2009. Disponível em: $<$ http://mapas.mma.gov.br/geodados/brasil/vegetacao/vegetacao2002/cerrado/documentos/rel atorio_final.pdf $>$. Acesso em: Nov/2014.

RANDS, M.R.W.; ADAMS, W.M.; BENNUN, L.; BUTCHART, S.H.M.; CLEMENTS, A.; COOMES, D.; ENTWISTLE, A.; HODGE, I.; KAPOS, V.; SCHARLEMANN, J.P.W.; SUTHERLAND, W.J.; VIRA, B.. 2010. Biodiversity Conservation - Challenges Beyond2010. Science, vol. 329 sep/2010

RAFFESTIN, C. Por uma Geografia do Poder. São Paulo: Ática, 1993

RAMIREZ, M. R. Sistemas Gerenciadores de Bancos de Dados para Geoprocessamento. Dissertação de Mestrado. Rio de Janeiro: COPPE/UFRJ, 1994.

REATTO, A.; MARTINS, E.S.; FARIAS, M.F.R.; SILVA, A.V. Reconhecimento de alta intensidade dos solos da APA de Cafuringa. In: APA de Cafuringa: a última fronteira natural do DF. Brasília, SEMARH. 2006. p. 59 - 65.

RIBEIRO, J.F. \& WALTER, B.M.T. 2008. As principais fitofisionomias do bioma Cerrado. Pp. 153-212. In: S.M. Sano; S.P. Almeida \& J.F. Ribeiro, (eds.). Cerrado: ambiente e flora. Embrapa Cerrados, Planaltina. p.151 -212.

RIBEIRO, J.F.; WALTER, B.M.T. EMBRAPA. Vegetação florestal: Mata Seca. Disponível em:

<http://www.agencia.cnptia.embrapa.br/Agencia16/AG01/arvore/AG01_67_911200585234.h tml>. Acesso em 05 jul. 2016.

RICKLEFS, R.E. A Economia da Natureza - 6 ${ }^{\text {a }}$ Ed. 2010. Editora Guanabara Koogan, Rio de Janeiro, RJ. Brasil. 2010. ISBN 9788527716772

RIO20. Disponível em: <http://www.rio20.gov.br/> Acesso em: 02 nov.2015

RODRIGUES, D.D. 2011. A construção da sustentabilidade e os desafios à conservação da biodiversidade: Unidades de Conservação e gestão de recursos naturais em Londrina PR. Universidade Estadual de Londrina. Londrina - PR, 2011.

RODRIGUES, E. 2002. Biologia da Conservação: a Ciência da crise - Semana Ciências Agrárias, Londrina, v. 23, n. 2, p. 261-272, jul/dez. 2002

ROSS, J. L. S. Geomorfologia: ambiente e planejamento. São Paulo. Contexto, 1991. 
RUDOLPHO, L.S.; BRAGHIROLLI, G.; REFOSCO, J.C.; SANTIAGO, A.G.; SABOYA, R.T. Aplicação de técnicas de geoprocessamento e métricas da paisagem na análise temporal da cobertura florestal da Bacia do Ribeirão Fortaleza em Blumenau/SC. In: SIMPÓSIO BRASILEIRO DE SENSORIAMENTO REMOTO, XVI., 2013, Foz do Iguaçu, Anais... Foz do Iguaçu: INPE, 2013. p. 1742-1749.

RUHOFF, Anderson L. Gerenciamento de recursos hídricos em bacias hidrográficas: Modelagem ambiental com a simulação de cenários preservacionistas. Santa Maria, UFSM, 2004.

RUNTE, Alfred. National parks: the American experience. Nebraska: Nebraska Univ. Press, 1997. $3^{\text {a }}$ edição. Diponível em: http://www.nps.gov/parkhistory/online_books/runte1/index.htm Acesso em: 26 out. 2015.

SANTANA, O.A.; ANJOS, H.O.; CARDOSO. E.; TANAJURA, E.V.; BERLINCK, C.N.; SANTOS, F.H.; GURGEL-GONÇALVES, R.; ENCINAS, J.I. Bacia do Maranhão: Diagnóstico das Áreas Preservadas utilizando técnicas de geoprocessamento. In: SIMPÓSIO BRASILEIRO DE SENSORIAMENTO REMOTO, XII., 2005, Goiânia. Anais... Goiânia: INPE, 2005. p. 1977-1987.

SANTOS, A.M.; REIS, R.D.; ANDRADE, N.L.R.; ROSA, A.L.D.; SOUZA, J.G.R. Sensoriamento Remoto orbital e SIG aplicados a análise espacial de áreas degradadas na cidade de Ji-Paraná, Rondônia. In: SIMPÓSIO BRASILEIRO DE SENSORIAMENTO REMOTO, XV., 2011, Curitiba. Anais... Curitiba: INPE, 2011. p.0667.

SANTOS, M.A.; SCHETTINO, S.C.; BASTOS, I.A.H. Educação ambiental em Unidades de Conservação: o caso da área de proteção Morro do Urubu. Ambivalências - Revista do Grupo de Pesquisa "Processos Identitários e Poder" - GEPPIP V. 01, n. 1, jan-jun/2013.

SANTOS, R.F. Planejamento ambiental: teoria e prática. São Paulo: Oficina de Textos, 2004.

SARTORI, A. 2004. Avaliação da classificação hidrológica do solo para determinação do excesso de chuva do método do serviço de conservação do solo dos Estados Unidos. Dissertação de Mestrado, Instituto de Engenharia Civil, Universidade de Campinas. 159p

SEBRAE - Serviço de Apoio às Micro e Pequenas Empresas do Distrito Federal / MMA Ministério do Meio Ambiente. Metodologia para Implementação de Sistema de Gestão Ambiental em Unidades de Conservação SGA-UC, 2007. Brasília - DF.

SEPKOSKI JUNIOR, J.J. Mass extinctions, concept of - Encyclopedia of Biodiversity, Vol 4. 2001.

SHIRAISHI J.C. Conflitos ambientais em Unidades de Conservação: percepções sobre a Reserva Biológica da Contagem, DF. 2011. Dissertação (Mestrado em Desenvolvimento Sustentável) Centro de Desenvolvimento Sustentável. Universidade de Brasília, Brasília, 2011. 
SILVA, I.O.R. \& FRANCISCHETT, M.N. 2012. A relação sociedade-natureza e alguns aspectos sobre planejamento e gestão ambiental no Brasil. Revista GeoGraphos $n^{\circ} 24.24$ de febrero de 2012. DOI: 10.14198/GEOGRA2012.3.24

SILVEIRA, L.; JÁCOMO, A.T.A.; FURTADO, M.M.; TORRES, N.M.; SOLLMANN, R.; VYNNE, C. Ecology of the Giant Armadillo (Priodontes maximus) in the Grasslands of Central Brazil. Edentata, 8-10: 25-34. 2009.

SISNAMA/MMA - Disponível em: http://www.mma.gov.br/governanca-ambiental/sistemanacional-do-meio-ambiente Acesso em: 22 out. 2015.

SMA - Secretaria de Estado de Meio Ambiente. Calibração do sistema relacional de correlação do manejo do território e da qualidade ambiental para o Reservatório Billings - Relatório Parcial RT-2. São Paulo, SMA, 2003.

SMA - Secretaria de Estado de Meio Ambiente. Elaboração do Plano de Desenvolvimento e Proteção Ambiental da Bacia Hidrográfica do Reservatório Billings - Relatório Final. São Paulo, Maio 2010.

SOBRAL, L.T. Filmagens aéreas da Reserva Biológica da Contagem e áreas limítrofes. Sobradinho, DF. 2016. 1 vídeo.

SOBRAL, L.T. Fotografias aéreas da Reserva Biológica da Contagem e áreas limítrofes. Sobradinho, DF. 2016a. 3 fotografias.

SOUZA, F. M. N.; SILVA, C. E.; AGUIAR, L. A.; ALMEIDA, J. R. Análise de riscos como instrumento para sistemas de gestão ambiental. Revista Ibero-Americana de Ciências Ambientais, Aquidabã, v.3, n.1, p.17-41, 2012.

STEINKE, V.A.; ARAÚJO. S.C.S.; STEINKE, E.T.; SAITO, C.H. Estimativa de exportação de cargas poluidoras em bacia hidrográfica por geoprocessamento. In: SAITO, Carlos Hiroo (org.). Desenvolvimento tecnológico e metodológico para mediação entre usuários e comitês de bacia hidrográfica. Brasília, Universidade de Brasília, 2004. p. 25-40.

STEINKE, V.A.; QUEIROZ, C.P.; SAITO, C.H. Estratégias de Sustentabilidade. In: FONSECA, Fernando Oliveira. Águas Emendadas. Brasília : Secretaria de Desenvolvimento Urbano e Meio Ambiente, Brasília, 2008.

TERRACAP. $2016 . \quad$ Disponível em: <http://www.terracap.df.gov.br/sistemasInternet/consultaOcupacao/uc/manterConsultaOcupac ao/index.php> Acesso em: 20 mai. 2016.

TONG, S.T.Y; CHEN, W. Modeling the relationship between land use and surface water quality. Journal of Environmental Management (2002) 66, 377-393.

TUNDISI, J.G. E MATSUMURA-TUNDISI, T. 2008. Biodiversity in the Neotropics_ecological, economic and social values. Instituto Internacional de Ecologia IIE, São Carlos - SP, 2008. 
VALERI, S. V.; SENÔ, M. A. A. F. A importância dos corredores ecológicos para a fauna e a sustentabilidade de remanescentes florestais. In: Congresso Internacional de Direito Ambiental. São Paulo. v. 1, p. 699-709, 2004.

VELASCO, D.; GARCÍA-LLORENTE, M.; ALONSO, B.; DOLERA, A.; PALOMO,I.; INIESTA-ARANDIA, I.; MARTÍN-LÓPEZ, B. Biodiversity conservation research challenges in the 21st century_a review of publishing trends in 2000 and 2011. Environmental Science \& Policy 54 (2015) 90-96. 2015.

VIANA M.V.; PINHEIRO, L.A.F.V. Conservação da biodiversidade em fragmentos florestais. ESALQ/USP. SÉRIE TÉCNICA IPEF v. 12, n. 32, p. 25-42, dez. 1998

VIEIRA JÚNIOR, W. C. J. Invasores ameaçam destruir sítios arqueológicos descobertos na Reserva Biológica da Contagem. 2009. Disponível pela ABN - Agência Brasileira de Notícias, em: <http://www.abn.com.br/noticias_anteriores1.php?id=47835>. Acesso em: 20 maio. 2016.

VILELA- MORALES, E. A. ; VALOIS, A. C. C. Recursos Genéticos vegetais autóctones e seus usos no desenvolvimento sustentável. Cadernos de Ciência \& Tecnologia, Brasília. v. 17 n. 2. 2000. p. 11-12

VON SPERLING, M. Introdução à qualidade das águas e ao tratamento de esgotos. $2^{\mathrm{a}}$ edição. Belo Horizonte: Departamento de Engenharia Santária e Ambiental; Universidade Federal de Minas Gerais. 1996.

ZACCARELLI, S. B. Estratégia e sucesso nas empresas. São Paulo, SP: Saraiva. $2^{a}$ edição. 2012

ZHAN, X. \& HUANG, M.L. 2004. ArcCN-Runoff: an ArcGIS tool for generating curve number and runoff maps. Environmental Modelling \& Software 19 (10) 875-879. 


\section{APÊNDICE}

APÊNDICE A - Perguntas direcionadas ao servidor do ICMBio, da equipe de trabalho da Reserva Biológica da Contagem, Enrique Mienza Balbuena.

\section{Quais os principais conflitos e situações preocupantes na área da Reserva e o que tem sido feito para resolvê-los?}

Uma grande dificuldade que a UC enfrenta é a presença de pessoas no interior da Reserva. Na parte mais ao sudoeste dela existe um galpão dos Correios abandonado, onde funcionou a primeira central de distribuição dos Correios do Distrito Federal e atualmente existem três famílias morando lá, que são de funcionários dos Correios. Essas famílias já deveriam ter saído, já foi feita a solicitação para os Correios pra que mandassem a área para o ICMBio, mas ainda está num impasse. Porém, não estamos cobrando, porque bem ou mal com essas famílias presentes no local também é uma forma de coibir um pouco situações como incêndios, queimadas e presença de mais pessoas frequentando a Reserva, que mesmo com a presença dessas famílias ainda acontecem no lugar.

Pelo fato da Reserva não ser muito bem cercada as pessoas conseguem entrar nela muito facilmente. Elas usam as estradas e trilhas para se deslocarem do Lago Oeste até a Vila Basevi, onde têm acesso a serviços, mercados e escola. São passagens de servidão que são bem complicadas de serem fechadas porque a comunidade usa bastante.

Na parte leste existe outra situação de acesso à Reserva por conta das cachoeiras do Ribeirão Contagem, que são frequentadas desde quando a população começou a se instalar em Brasília com a transferência da capital para o centro do país. Desde 2002 com a criação da Reserva os frequentadores estão proibidos de ir, por conta da categoria de Reserva Biológica, que pela legislação não permite visitação como recreação, só com atividades de educação ambiental ou pesquisas. Contudo, as cachoeiras ainda continuam sendo frequentadas ilegalmente, o que gera uma situação bastante ruim e um dos aspectos pelos quais estamos tentando mudar a categoria da Unidade de Conservação.

Aliás, a criação da Reserva tem uma relação muito forte com as captações de água do córrego Paranoazinho e do Ribeirão da Contagem, que são super importantes. Essa foi uma das implicações para sua criação e a outra foi a de que Grande Colorado estava crescendo demais e a área da Reserva já estava sendo preparada para ampliar a ocupação. Além disso, 
ainda temos a presença da Vila Basevi e do Lago Oeste, a preocupação maior era que tudo virasse uma ocupação só.

Se essa área urbana chegar no Lago Oeste a situação ficará extremamente preocupante, porque hoje ela é considerada área rural e ela está no mínimo parcelamento possível para tal, que é 2 hectares, se passar disso ela não consegue mais se regularizar como área rural e já existem alguns lotes nessa situação, que já estão se subdividindo, mas o maior problema é que a impermeabilização dessa área vai trazer sérias consequências para os aquíferos e essa é uma grande área de recarga, no topo da Chapada, na área mais plana, é um perigo gigantesco que isso aconteça.

Outras preocupações do ICMBio, aí já relacionando o PARNA Brasília, o Lago Oeste e o restante das áreas vizinhas, são os corredores de fauna. Entre o parque e a Reserva a estrada já é um grande empecilho. E se o Lago Oeste se adensar, aí as consequências serão piores.

Nós não temos como ficar impedindo que o pessoal entre na Reserva, então nós avaliamos se a categoria de Reserva Biológica é a mais adequada para a área ou não e junto a outros trabalhos de outros grupos, chegamos a conclusão de que não vale a pena manter a UC como Reserva Biológica. Foram avaliados vários critérios e a melhor categoria para a área é a de Parque Nacional.

2. Os moradores do Grande Colorado fizeram uma vez um abaixo-assinado pedindo uma área de 194 hectares que pertence à Reserva da Contagem para a criação de um parque ecológico (Nascimento, 2014). Qual a posição de vocês sobre a ideia de destinar uma parte da Reserva como parque ecológico ao invés de modificar seu status para Parque Nacional?

Isso seria mais complicado, o melhor seria recategorizar por completo, porque quando você recategoriza como Parque, você já dá essa oportunidade para as pessoas frequentarem o local e não seria como se fosse num parque ecológico, em que frequentariam o local com cachorros, que é isso o que os moradores podem ter interesse. Quando você diminui demais a categoria de conservação, que seria para transformar em parque urbano, você está diminuindo o poder de proteção dessas áreas. 


\section{Mas em compensação seria só uma parte da Reserva que viraria parque urbano, o restante continuaria como Reserva Biológica, que protege mais por ser o status de UC mais restritivo de todos.}

É uma possibilidade a se pensar, não se pode simplesmente dizer que não, eu acho que tem que ser avaliado, mas é que por trabalhar na área de conservação nós acabamos enxergando melhor essa forma de recategorização de uma vez, principalmente por conta da legislação, porque pra legalizar é preciso fazer um projeto de lei para desafetar a Reserva e criar como parque, pois você já está diminuindo o grau de proteção saindo de uma mais restritiva para uma menos restritiva e para isso acontecer é só através de lei no Congresso. É muita burocracia todo esse processo, aí para fazer isso e ainda passar uma parte para o GDF fazer um parque específico torna a demanda mais complicada, então pode ser mais fácil o processo de recategorizar tudo do que ficar fazendo pequenos cortes na área.

\section{Existem ocupações particulares no interior da Reserva?}

Ainda existem cerca de 40 famílias dentro da Reserva e mais 13 casas da Vila Basevi que estão dentro do território da UC e essas casas teriam que ser indenizadas.

A área da União é somente a parte superior da Reserva (região da chapada), a parte inferior é área particular, então as pessoas teriam que ser indenizadas quanto às benfeitorias e também às propriedades.

Também existem trechos do Clube do Empresário que estão dentro da unidade, não funciona mais nada no local, mas também precisariam ser indenizados.

Nesse processo de recategorização foi comentado tudo isso. Nós imaginamos que o melhor seja ampliar a área da Basevi para não precisar tirar essas pessoas dali e englobar a área do Clube do Empresário, porque de qualquer forma teríamos que indenizar a área toda, não tem como indenizar só um trecho, indeniza-se toda a propriedade, então já englobava a área toda.

Há um processo de regularização para a Chácara Carolina, outra ocupação no interior da unidade, e já tínhamos dinheiro para pagar, mas houve contestação dos proprietários, que não aceitaram os valores que foram oferecidos. A especulação imobiliária em Brasília é muito grande e eles colocam os valores venais muito baixos, então quando os moradores precisam 
ser indenizados por conta de reintegração de posse, vão receber pelo valor venal e não pelo valor de mercado, assim os proprietários contestam, tornando a situação bastante complicada.

Como as ocupações são anteriores à criação da unidade, elas podem permanecer lá até serem indenizadas, o problema é ter dinheiro para indenizar. A Basevi é um caso a parte porque está fora da unidade, a única coisa que podemos falar a respeito dela é no licenciamento do empreendimento, ou seja, a regularização da Vila Basevi.

\section{E quantos aos impactos ambientais gerados pela Vila Basevi?}

A Vila Basevi é bastante impactante para a Reserva, inclusive já foram feitos vários autos de infração por causa dos problemas no local, como o das fossas extravasando, que lançam dejetos para dentro da unidade. Além disso, muitos focos de incêndio tem início em áreas adjacentes a Vila. Outro problema é a questão do lixo, em que os moradores jogam seus lixos e entulhos pela janela. E a área que recebe esses lixos é a Reserva, tal a proximidade com a Basevi.

\section{A área da Vila Basevi pertence à União?}

A Vila Basevi está na área da União e não foi regularizada ainda, foi repassada pro GDF, mas ainda está em processo de regularização.

Este é até outro embrolho, porque nós somos $100 \%$ a favor de regularizar a Basevi, mas junto com a área da vila está a de duas usinas de asfalto que não funcionam mais. As usinas até tinham licenças, mas o ICMBio não tinha sido ouvido, então eram licenças irregulares. Após muita briga conseguimos fazer com que as usinas parassem de funcionar por conta dos impactos ambientais e em contrapartida o GDF queria levar 320 famílias para morar lá...

\section{As usinas não funcionam mais?}

As usinas não funcionam mais, as áreas ainda permanecem com algumas pessoas no local e ficou servindo como depósito para guardarem as máquinas e materiais da usina, mas é uma área que não faz parte da Reserva. 


\section{O que funciona na área demarcada como pasto, de acordo com a classificação de}

uso e ocupação do solo da Terracap do ano de 2010 (classificação utilizada neste trabalho)?

Essa é uma área de cerrado degradado, tem bastante andropogon, um gênero de gramínea exótica invasora. Ele domina o estrato herbáceo e dificulta para as gramíneas nativas, mas essa área plana do reverso da chapada é bastante degradada mesmo, são quase 100 hectares de andropogon puro, porque era uma área de plantio e era uma área que estava sendo guardada para especulação mobiliária.

O restante do reverso da chapada é como se fosse um campo sujo e um cerrado sentido restrito em algumas áreas, meio ralo, mas já com formação de Cerrado, mas o impacto como área degradada é realmente bastante grande nessa parte e em toda a parte mais alta da Reserva, no topo da chapada.

E o que eu acho interessante na ReBio é esse gradiente de fisionomias que ela tem. Ela tem a região da Chapada, a encosta da Chapada e uma parte mais movimentada na parte baixa, isso traz uma variação fisionômica bem interessante.

\section{Quais as principais dificuldades operacionais?}

Houve uma redução muito grande no número de servidores do ICMBio, principalmente no Parque e com isso a equipe da ReBio foi praticamente incorporada à equipe do Parque e com isso não estamos realizando tantas atividades na unidade mesmo.

\section{E por que não existe uma sede do ICMBio dentro da ReBio da Contagem?}

A Reserva não possui uma sede do órgão instalada em seu território e ainda faltam recursos financeiros para recuperar alguns locais que poderiam servir a este propósito.

Uma opção de local para a instalação da sede da Reserva seria uma casa de um antigo morador que entrou na justiça contra a União e foi indenizado, liberando a ocupação do imóvel instalado dentro da área da ReBio. O ICMBio já recebeu essa casa e tentou transformar na sede da unidade, porque a localização também é muito boa, mas para transformar teria que ter no local ao menos internet, vigilância e limpeza.

A internet seria fácil de conseguir, então teriam que resolver o problema da vigilância e limpeza. Após uma semana da ideia de estabelecer a sede ali, disseram que não seria 
possível, pois teriam que deslocar terceirizados da Sede do ICMBio para Reserva e a empresa não gostou muito da ideia e não aceitou, não mediram muitos esforços para isso. Hoje o imóvel virou uma casa funcional, uma servidora do Parque que já morava na Vila Basevi está morando lá e ainda estamos sem nossa sede.

\section{O que vocês pensam sobre a possibilidade de criar corredores ecológicos entre o PARNA Brasília e a ReBio da Contagem?}

Neste documento de avaliação para recategorizar a área também foi considerado incorporar outras áreas, seria juntar com o PARNA Brasília pela parte de baixo do Lago Oeste, englobando justamente a parte que ninguém vai usar que é a parte de encostas e dar uma proteção maior nesta região, porque já é possível ver alguns processos de ocupação que estão começando nessa área, mas esses são os piores de todos, pois nessa área a declividade é muito grande, então qualquer processo de intervenção leva à erosão. Isso vai acontecer e já tem acontecido.

Outras áreas de interesse, são áreas nas cabeceiras do Rio Maranhão. Essas áreas também são de grande importância para a conservação, são áreas de mata seca e já vêm sofrendo um processo de degradação por conta de carvoarias, desmatamento e uma série de coisas e ela também é alvo das cimenteiras, que apresentam grande interesse no calcário e o calcário é justamente o que propicia a mata seca. A mata seca é um tipo de fitofisionomia florestal que não está relacionada com a água, está relacionada com o substrato, e se a gente tivesse um ranking de fitofisionomias ameaçadas de extinção a mata seca estaria entre os primeiros, porque ela é rara e a força de impactos negativos sobre ela é gigantesca, devido a esses interesses todos. Então foi proposta a ampliação da Reserva para essas áreas, encerrando justamente na zona de amortecimento da Estação Ecológica de Águas Emendadas (ESECAE), possibilitando assim um corredor ecológico entre essas UCs.

Outra informação obtida de antemão e de suma importância para a conservação da área é que o pessoal do NEX - No Extinction está fazendo uma pesquisa com câmeras trap, monitorando os mamíferos de médio e grande porte, principalmente os felinos, e algumas dessas câmeras foram instaladas na região de Águas Emendadas e na Bacia do Maranhão e registraram a presença de onça pintada, um animal que segundo pesquisadores e publicações de artigos foi considerada extinta do Distrito Federal. Através desses registros eles identificaram várias onças: fêmeas grávidas, outras fêmeas e indivíduos melânicos e não 
melânicos, mostrando que não é pouca a quantidade de indivíduos. Isso mostra que essa área é mais importante do que se imaginava.

O projeto de recategorização foi para a sede do ICMBio e ainda está em análise e modificação, mas não sei informar exatamente como está agora, por conta das mudanças de governo. Em breve haverá reunião para saber como estudar melhor essas áreas e ver o quanto de esforço pode ser necessário para conseguir mostrar a importância da região para a conservação da biodiversidade.

\section{Em algumas leituras sobre a Reserva eu encontrei a informação que existem} explorações minerais clandestinas na área da Reserva (Nascimento, 2006), você sabe se isso procede?

Não, se teve já foi há bastante tempo, mas desde as últimas vezes que andamos por lá, não vimos mais sinais de mineração. A propósito, uma das ideias caso a Reserva mude de status para Parque é a de transformar as cascalheiras, que são áreas de mineração bem antigas, da época da construção de Brasília, em piscinas, como as do PARNA Brasília. Essa seria a melhor forma de recuperar essas áreas, que chamamos de reabilitação. A restauração ambiental nessas áreas seria muito cara e talvez não trouxesse bons resultados. A transformação dessas cascalheiras em piscinas de água natural, após a recategorização de Reserva Biológica para Parque Nacional, reabilitaria esses espaços e se transformariam em novos atrativos para esse novo Parque, que além das visitas às cachoeiras, também é bastante frequentado por ciclistas. Impedir que essas pessoas entrem na Reserva, significa trabalhar sete dias por semana, em mais de 10 entradas diferentes, tentando barrar os visitantes. É por isso que nós acreditamos que a recategorização, além de regularizar a visitação, também vai aproximar positivamente as pessoas e a Reserva Biológica da Contagem, mas aí já como Parque Nacional.

13. A Reserva da Contagem ainda não possui plano de manejo. Gostaria de saber o que você teria a dizer a respeito, se já existe um esboço desse plano ou não e se existe uma previsão de quando será elaborado.

Quanto ao Plano de Manejo, existiram duas iniciativas. A primeira foi justamente no período que as Usinas de Asfalto foram embargadas. Para que elas pudessem trabalhar por 
mais um ano e finalizar suas atividades, foi firmado com cada uma delas um Termo de Compromisso (ou Termo de Ajuste de Conduta, não lembro o termo exato). Cada termo tinha como condicionante a apresentação de algum estudo, que depois subsidiaria a elaboração do Plano de Manejo. Mas essas foram condicionantes que, se não me falha a memória, não foram cumpridas por nenhuma das usinas.

A última iniciativa é mais recente. A um pouco mais de um ano, iniciamos as discussões para a contratação de uma consultoria para a elaboração do Plano de Manejo. A possibilidade de contratação surgiu a partir de recursos de compensação ambiental que a Reserva recebeu. A intenção era justamente conciliar a elaboração do Plano da Reserva com a revisão do Plano do Parque Nacional de Brasília, que também tinha recursos de compensação ambiental. A última informação que tenho é a de que todos os recursos de compensação ambiental, acredito que de todas as Unidades de Conservação federais, foram recolhidos pelo governo central, provavelmente por causa da crise financeira do governo. Mas não sei qual será a destinação desse recurso, se ele voltará ou não para as unidades.

14. Existe algum projeto de sustentabilidade para a área da Reserva ou nas suas redondezas (projetos que já estão em ação ou que ainda estejam somente no papel)? A equipe do ICMBio tem realizado ou tem planos de realizar ações de sustentabilidade no local? Quais seriam essas ações? Existem parcerias nesse sentido?

Sobre as ações de sustentabilidade, o que de concreto acontece na Reserva é a fiscalização contra ilícitos ambientais e um projeto de restauração ambiental, justamente na área de Andropogon que comentei anteriormente. É um projeto de pesquisa, com intervenções com diversos modelos de plantio, utilizando plantio direto, sem uso de mudas, em que as sementes foram colhidas na própria unidade. Já temos resultados interessantes, pois os experimentos tem mais de três anos.

Além disso, existe uma iniciativa de um grupo de pessoas, vinculadas a uma instituição ecumênica, que iniciou um projeto de sensibilização e educação ambiental no interior da Reserva, na região próxima ao Lago Oeste, onde fica a instituição. Toda a atividade é desenvolvida por eles, num projeto piloto, que foi avaliado, acompanhado e autorizado por nós. Nós esperamos que este projeto gere bons resultados. 
Mas o projeto que imaginamos que dê maior sustentabilidade à unidade, não em termos econômicos, pois qualquer recurso arrecadado é encaminhado ao caixa único da União, é o processo de recategorização. A partir da recategorização da Reserva, ela tem o potencial de ter uma série de atividades ligadas ao ecoturismo, turismo de aventura e recreação, que pode gerar benefícios sociais e econômicos para as comunidades do entorno da unidade e, com isso, minimizar os impactos ambientais negativos gerando sustentabilidade ambiental, que é o que efetivamente queremos para essa porção do território do Distrito Federal. 